\author{
UNIVERSIDADE DE SÃO PAULO \\ FACULDADE DE CIÊNCIAS FARMACÊUTICAS \\ Programa de Pós-Graduação em Ciências dos Alimentos \\ Área de Bromatologia
}

\title{
Comportamento de Salmonella em ovo em pó em função \\ da Atividade de Água (Aa) e do binômio Tempo x Temperatura de Armazenamento.
}

Gunnar Martin

\author{
Dissertação para obtenção do grau de \\ MESTRE \\ Orientador: \\ Profa. Dra. Bernadette Dora Gombossy \\ de Melo Franco
}

São Paulo

2005 
Ficha Cat alográfica

Elaborada pela Divisão de Biblioteca e

Documentaçào do Conjunto das Químicas da USP.

Martin. Gunnar
Comportamento de Salmonella em ovo em pó em funçào da
atividade de água (Aa) e do binómio tempo x temperatura de
armazenamento Gunnar Martin. -- Sào Paulo. 2005.
66p.
Dissertaçào (mestrado) - Faculdade de Ciências Farmacétuticas
da Universidade de Sào Paulo. Departamento de Alimentos e
Nutriçào Experimental.
Orientador: Franco. Bernadette Dora Gombossy de Melo
1. Microbiologia de alimentos 2. Samonella: Bacteriologia
Ovos : Ciència dos alimentos 1. T. II. Franco. Bernadette
Dora Gombossy de Melo. orientador.




\section{Gunnar Martin}

Comportamento de Salmonella em ovo em pó em função da Atividade de Água (Aa) e do binômio Tempo $x$ Temperatura de Armazenamento.

Comissão Julgadora da dissertação para obtenção do grau de Mestre

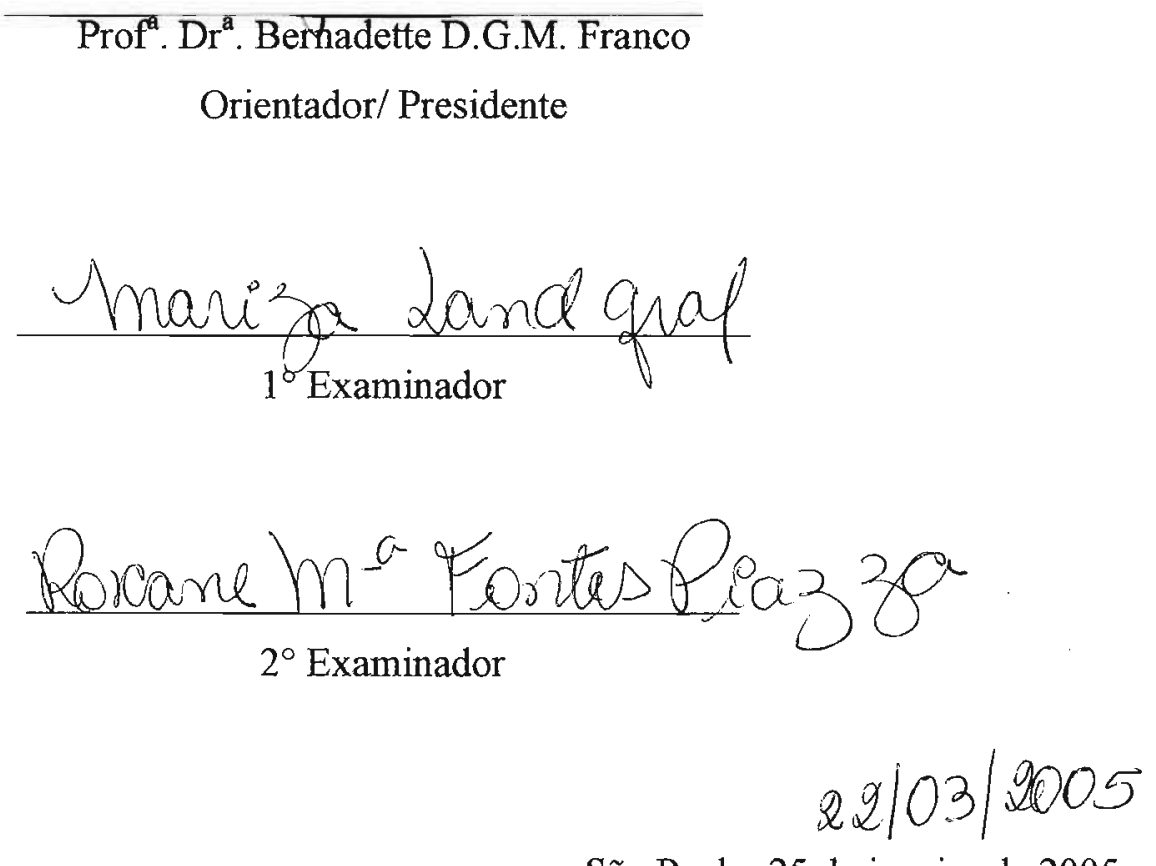

São Paulo, 25 de janeirade 2005. 
Dedico

Aos meus pais, Immo e Miriam, por toda paciência e carinho.

Ao meu grande irmão, Ian e a meu futuro sobrinho.

A Mônica por todo seu carinho e companheirismo.

E a meus amigos que me acompanham desde de minha infância. 
Agradecimentos

À prof ${ }^{a} \operatorname{Dr}^{a}$ Bernadette D.G.M. Franco, pela orientação, paciência e por tudo que me ensinou.

À professora Maria Teresa Destro, por ter me ajudado sempre que necessário e por ter puxado minha orelha quando necessário.

À professora Mariza Landgraf, pelo apoio no laboratório e por suas críticas construtivas feitas no exame de qualificação.

À professora Roxane Maria Fontes Piazza, por sua contribuição ao trabalho durante o exame de qualificação.

À Jane Gelinski, por ter me ensinado grande parte do que sei de microbiologia e por ter me agüentado como estagiário.

Às técnicas e grandes companheiras, Kátia e Lucia, pelo agradável convívio no laboratório e por sua grande ajuda.

Ao Paulo de Souza Costa Sobrinho por ter feito a análise estatística deste trabalho.

Aos meus amigos de laboratório: Lina, Cecília, Ângela, Tatiana, Gabriela, Daniela, Antônio, Janine, Monika, Cíntia, Cristina, Alexandra, Dory, Kátia Lima, Alcina, Cristiano, Vinícius, Ricardo, Vanessa, Vanessa Tsuhako, Patrícia, Hans, Patrícia Kary, Luciano, Fábio, Caio, Viviane e outros que passaram, pelo companheirismo e troca de conhecimentos.

À CAPES pela concessão da bolsa de estudo e à Fundação de Amparo à pesquisa (FAPESP) pelo apoio financeiro para a realização deste trabalho e a empresa Kayatonas pelo fornecimento do produto.

Às secretárias do departamento e à todos da secretaria de Pós-Graduação, pelo serviço prestado. 


\section{INDICE}

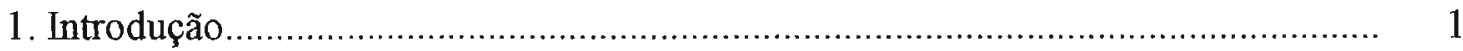

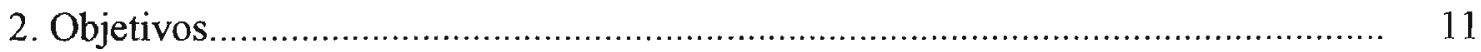

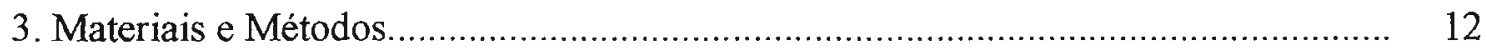

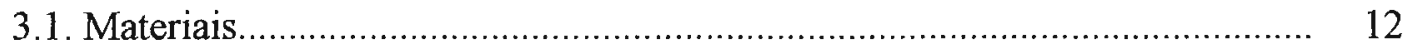

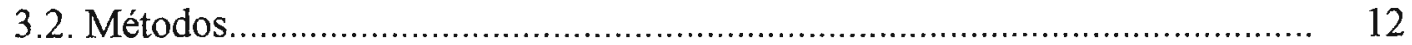

3.2.1. Manutenção da cultura de Salmonella ............................................... 12

3.2.2. Padronização do inóculo de Salmonella ............................................ 12

3.2.3. Preparo do ovo para inoculação experimental..................................... 13

3.2.4. Inoculação experimental do ovo em pó............................................... 13

3.2.5. Armazenamento do ovo experimentalmente contaminado.................. 14

3.2.6. Enumeração de Salmonella no ovo.................................................. 15

3.2.7. Contagem total de bactérias aeróbias mesófilas................................. 17

3.2.8. Contagem total de coliformes..................................................... 17

3.2.9. Analise estatística................................................................. $18 \neq 17$

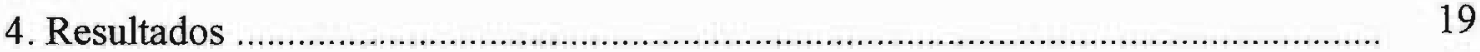

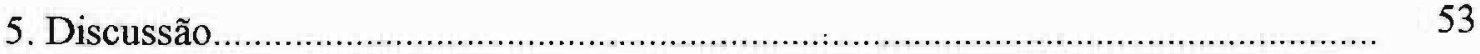

6. Conclusões................................................................................................ 58

7. Referência Bibliográfica............................................................................ 59

Anexos 


\section{Resumo}

Salmonella sp. é um dos principais microrganismos causadores de surtos de enfermidades transmitidas por alimentos associados ao consumo de ovos e de alimentos formulados com este ingrediente. Ovos desidratados são largamente utilizados pelas indústrias de alimentos, por oferecer maior praticidade e maior padronização em relação ao produto "in natura". Apesar do processo tecnológico de desidratação do ovo incluir uma etapa de pasteurização, existe um risco de haver microrganismos sobreviventes, já que a pasteurização é feita em temperatura branda. Além disso, a pasteurização pode destruir os fatores intrínsecos antimicrobianos presentes na clara, possibilitando a multiplicação de microrganismos que sobreviveram ao processo de pasteurização ou que contaminaram o produto após a pasteurização. O controle da Aa do produto desidratado e o tempo de armazenamento são, portanto, fatores fundamentais para o controle da multiplicação de microrganismos indesejáveis. Nesse estudo, avaliou-se a cinética de multiplicação de Salmonella experimentalmente adicionada a ovo em pó Aa ajustada para $0,4,0,6,0,8$ e 0,9, durante o armazenamento em quatro temperaturas: $8^{\circ} \mathrm{C}, 15^{\circ} \mathrm{C}, 25^{\circ} \mathrm{C}$ e $35^{\circ} \mathrm{C}$. Os resultados indicaram que $S$. Enteritidis é capaz de sobreviver por longo tempo (pelo menos 56 dias) em ovo em pó com Aa próximo de 0,4 quando armazenado a $8^{\circ} \mathrm{C}, 15^{\circ}$ e a $25^{\circ} \mathrm{C}$. Essa sobrevivência é menor (até 28 dias) quando o armazenamento é feito a $35^{\circ} \mathrm{C}$. No ovo em pó com Aa em torno de 0,6 ou $0,8, S$. Enteritidis sobrevive por menos tempo do que no produto com Aa de cerca de 0,4 , independentemente da temperatura de armazenamento. No produto com Aa de cerca de 0,9 , há grande multiplicação de $S$. Enteritidis quando o armazenamento é feito a $15^{\circ} \mathrm{C}, 25^{\circ} \mathrm{C}$ ou $35^{\circ} \mathrm{C}$. Nesse produto, o armazenamento a $8^{\circ} \mathrm{C}$ impede a multiplicação do patógeno. Verificou-se também que Salmonella Hadar, resistente a diversos antibióticos, apresentou o mesmo comportamento que $S$. Enteritidis nas amostras de ovo estudadas. 


\begin{abstract}
Behavior of Salmonella in powdered egg according to its water activity (Aw) and time and temperature of storage.

Salmonella is one of the major foodborne pathogens associated to the consumption of eggs and foods containing eggs. Powdered eggs are widely used in the food industry because they are more convenient and uniform than the in natura product. Despite the existence of a pasteurization step in the drying process, Salmonella can survive because the pasteurization of eggs should be done under mild temperature. Moreover, pasteurization can destroy the intrinsic antimicrobial components of the albumen, making the multiplication of Salmonella possible when the time and temperature of storage are not appropriate. Thus, the water activity (Aw) of the product and the storage time and temperature are essential factors in the control of Salmonella. In this work, we evaluated the growth kinetics of Salmonella in experimentally inoculated powdered egg, adjusted to different Aw values $(0.4,0.6,0.8$ and 0.9$)$ during storage at $8^{\circ} \mathrm{C}, 15^{\circ} \mathrm{C}, 25^{\circ} \mathrm{C}$ and $35^{\circ} \mathrm{C}$, up to 8 weeks. The results indicated that Salmonella Enteritidis is able to survive for long time in powdered eggs (at least 56 days) when the Aw is close to 0.4 and the temperature is $8^{\circ} \mathrm{C}$, or $15^{\circ} \mathrm{C}$ or $25^{\circ} \mathrm{C}$. The survival is lower when the temperature is $35^{\circ} \mathrm{C}$. When the Aw is close to 0.6 or to 0.8 , the pathogen survives for less time than in the product with Aw 0.4 , regardless the storage temperature. When the Aw is close to 0.9 , there is an intensive growth of the pathogen when the storage is done at $15^{\circ} \mathrm{C}, 25^{\circ} \mathrm{C}$ or $35^{\circ} \mathrm{C}$. However, storage at $8^{\circ} \mathrm{C}$ inhibits the growth of Salmonella at this Aw. Salmonella Hadar, resistant to several antibiotics, presented the same growth pattern as $S$. Enteritidis.
\end{abstract}




\begin{abstract}
Behavior of Salmonella in powdered egg according to its water activity (Aw) and time and temperature of storage.

Salmonella is one of the major foodborne pathogens associated to the consumption of eggs and foods containing eggs. Powdered eggs are widely used in the food industry because they are more convenient and uniform than the in natura product. Despite the existence of a pasteurization step in the drying process, Salmonella can survive because the pasteurization of eggs should be done under mild temperature. Moreover, pasteurization can destroy the intrinsic antimicrobial components of the albumen, making the multiplication of Salmonella possible when the time and temperature of storage are not appropriate. Thus, the water activity (Aw) of the product and the storage time and temperature are essential factors in the control of Salmonella. In this work, we evaluated the growth kinetics of Salmonella in experimentally inoculated powdered egg, adjusted to different Aw values $(0.4,0.6,0.8$ and 0.9$)$ during storage at $8^{\circ} \mathrm{C}, 15^{\circ} \mathrm{C}, 25^{\circ} \mathrm{C}$ and $35^{\circ} \mathrm{C}$, up to 8 weeks. The results indicated that Salmonella Enteritidis is able to survive for long time in powdered eggs (at least 56 days) when the Aw is close to 0.4 and the temperature is $8^{\circ} \mathrm{C}$, or $15^{\circ} \mathrm{C}$ or $25^{\circ} \mathrm{C}$. The survival is lower when the temperature is $35^{\circ} \mathrm{C}$. When the Aw is close to 0.6 or to 0.8 , the pathogen survives for less time than in the product with Aw 0.4 , regardless the storage temperature. When the Aw is close to 0.9 , there is an intensive growth of the pathogen when the storage is done at $15^{\circ} \mathrm{C}, 25^{\circ} \mathrm{C}$ or $35^{\circ} \mathrm{C}$. However, storage at $8^{\circ} \mathrm{C}$ inhibits the growth of Salmonella at this Aw. Salmonella Hadar, resistant to several antibiotics, presented the same growth pattern as $S$. Enteritidis.
\end{abstract}




\section{Introdução}

Os ovos desidratados, integrais ou apenas gemas ou claras, constituem uma alternativa tecnológica ao uso de ovos frescos na indústria de alimentos. Os ovos desidratados apresentam diversas vantagens em relação aos ovos frescos, destacando-se menor susceptibilidade à deterioração de natureza microbiana, maior uniformidade, menor custo de estocagem, eliminação da interferência da casca (que chega a representar $13 \%$ do peso do ovo) e maior flexibilidade de uso na formulação de novos alimentos (Gordon, 1971; Aguirre et al., 1979; Carvalho et al., 1994; Barretto, 2001).

A utilização de produtos de ovos (integral, clara e gema) líquidos pasteurizados ou desidratados data do início do século, passando a ser produzidos em escala industrial a partir da $2^{\text {a }}$ guerra mundial. No Brasil, a utilização de ovos desidratados em escala industrial teve início em 1989. O Brasil é um grande produtor de ovos: segundo o Instituto Brasileiro de Geografia e Estatística, foram produzidos 2,6 bilhões de dúzias de ovos de galinha em 2002 (IBGE, 2002) e, de janeiro a junho de 2004, 942 milhões de dúzias de ovos (IBGE 2004).

O mercado de ovos desidratados, por apresentar uma produção recente no Brasil, apresenta uma grande oportunidade de crescimento, devido às suas vantagens de utilização em indústrias de massas, biscoitos, panificação, maioneses, molhos, margarinas, produtos cárneos empanados, fast-food e restaurantes industriais. Em 2000, esse mercado teve um crescimento de $20 \%$, acreditando-se que nos próximos 10 anos a produção de ovos industrializados deva crescer $10 \%$ ao ano. Enquanto a maioria (83\%) do ovo líquido pasteurizado industrializado é utilizada na fabricação de maioneses e massas, $95 \%$ dos ovos desidratados integrais destinam-se à indústria de massas e biscoitos, $80 \%$ das gemas desidratadas à fabricação de chocolates e biscoitos e $80 \%$ das claras desidratadas à indústria de marshmallow e confeitos (Barretto, 2001).

Sabe-se que os ovos apresentam estruturas que agem como barreiras de grande eficiência para a penetração e multiplicação de microrganismos. Uma das barreiras é constituída pela casca e suas membranas e outra, igualmente eficiente, são os componentes antimicrobianos da clara do ovo, entre os quais incluem-se a ovotransferrina, o pH elevado e a deficiência de ferro (Solomon et al., 1994; Sparks, 1994; Baron, Gautier \& Brule, 1997; Baron, Gautier \& Brulé, 1999; Losso, Nakai \& Charter, 2000; Ibrahim, 2000; Sim, Sunwoo \& Lee, 2000; Mine, 2000). 
Abaixo, pode-se ver um ovo esquematizado:

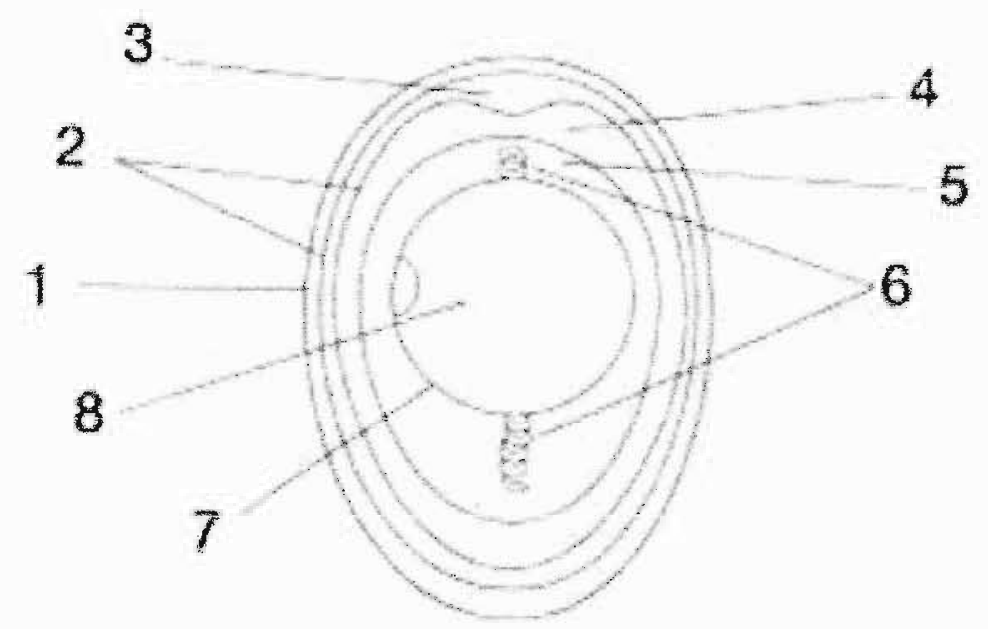

1. Casca

2. Membranas da casca

3. Câmara dc ar

4. Clara mais fluida
5. Clara mais viseosa

6. Chalazas

7. Mcmbrana vitclínica

8. Gema

Entretanto, o processo de desidratação do ovo pode alterar a eficiência destes componentes como agentes antimicrobianos. Por exemplo, Baron et al. (1999), ao inocular Salmonella Enteritidis em clara de ovos reconstituída a partir de clara de ovos em pó, observaram que a $30^{\circ} \mathrm{C}$ houve um rápido crescimento de Salmonella. O mesmo não foi observado em claras de ovos não submetidas à desidratação. Tal fato foi creditado à desnaturação protéica da ovotransferrina que ocorre durante o processo de secagem, levando à sua inativação.

O microrganismo patogênico de maior relevância em ovos é, sem dúvida, Salmonella. Algumas espécies de salmonela contaminam os ovos através de transmissão transovariana, enquanto outras penetram no ovo através de ruptura da casca contaminada com material fecal da própria ave ou durante a manipulação pelo homem (ICMSF, 1998; Jay, 2000; Franco et al., 2003).

O gênero Salmonella pertence à família Enterobacteriaceae e compreende bacilos Gram-negativos não produtores de esporos. $\Lambda$ maioria é móvel, através de flagelos 
peritríqueos, com exceção feita à $S$. Pullorum e $S$. Gallinarum, que são imóveis. São anaeróbios facultativos, fermentam D-glicose e outros carboidratos produzindo ácido e normalmente gás (exceto $S$. Typhi), são oxidase negativos, catalase positivos, indol e VogesProskauer negativos e são capazes de utilizar o citrato como única fonte de carbono. Descarboxilam lisina e ornitina, produzem $\mathrm{H}_{2} \mathrm{~S}$ e não hidrolizam uréia (Holt et al., 1994; Andrews \& Hammack, 2003).

A temperatura ideal para multiplicação de Salmonella sp. é de $35-37^{\circ} \mathrm{C}$, sendo a mínima de $5^{\circ} \mathrm{C}$ e a máxima de $47^{\circ} \mathrm{C}$. Vários estudos indicam, no entanto, que os valores máximo e mínimo dependem do sorotipo. $\mathrm{O}$ pH ótimo para a multiplicação desses microrganismos é próximo de 7,0, sendo que valores podem variar entre 4,5 e 9,0 (Holt et al., 1994; Jay, 2000).

Atividade de água é um parâmetro que mede a quantidade de água livre no alimento, sendo definida como sendo a relação existente entre a pressão parcial de vapor de água contida na solução ou no alimento e a pressão parcial de vapor da água pura, a uma dada temperatura (Franco \& Landgraf, 1996; Jay, 2000).

A atividade de água mínima para multiplicação de Salmonella é de 0,93. Este microrganismo não tolera concentrações de sal superiores a 4\%, mas sua tolerância aumenta com o aumento da temperatura na faixa de $10^{\circ} \mathrm{C}$ a $30^{\circ} \mathrm{C}$ (Holt et al., 1994; Jay, 2000).

A taxonomia do gênero Salmonella é baseada nas características bioquímicas e sorológicas, que incluem a composição de seus antígenos de superficie, que são os antígenos somáticos (O), os flagelares (H) e os capsulares (Vi) (Holt et al., 1994; Jay, 2000).

O genero Salmonella compreende duas espécies: $S$. enterica e $S$. bongori. S. enterica é dividida em seis subespécies: enterica, salamae, arizonae, diarizonae, houtenae e indica. Sorotipos pertecentes a $S$. enterica subespécie enterica são geralmente designados pelo nome do local onde o sorotipo foi isolados pela primeira vez. Esses nomes não são mais escritos em itálico e aparecem com a primeira letra maiúscula (Jay, 2000).

As doenças causadas por Salmonella $\mathrm{sp}$. costumam ser subdivididas em três grupos: febre tifóide causada por Salmonella Typhi, febres entéricas causadas por $S$. Paratyphi (A, B e C) e as enterocolites (ou salmoneloses) causadas pelas demais salmonelas (Franco \& Landgraf, 1996; Jay, 2000).

A febre tifóide só acomete o homem e normalmente é transmitida por água e alimentos contaminados com material fecal. Os sintomas são muito graves e incluem septicemia, febre alta, diarréia e vômitos. O reservatório de $S$. Typhi é o homem. Algumas pessoas se tornam portadores assintomáticos, que costumam ser a principal fonte de contaminação de água e 
alimentos, fazendo com que alguns casos de febre tifóide sejam associados ao consumo de leite cru, mariscos e vegetais crus (Franco \& Landgraf, 1996; Jay, 2000).

As febres entéricas são bastante semelhantes à febre tifóide, mas os sintomas clínicos são mais brandos. Geralmente ocorrem septicemia, vômitos e diarréia. Enquanto a febre tifóide pode se prolongar por oito semanas, as febres entéricas têm duração de, no máximo, três semanas. Estas doenças também podem ser causadas por consumo de água e alimentos, especialmente leite cru, vegetais crus, mariscos e ovos (Franco \& Landgraf, 1996; Jay, 2000).

As salmoneloses caracterizam-se por sintomas que incluem diarréia, febre, dores abdominais e vômitos que aparecem, em média, 12 a 36 horas após a ingestão do microrganismo, durando entre um e quatro dias. De modo geral, a enterocolite por Salmonella não necessita de tratamento com antibióticos. Nos recém-nascidos e crianças pequenas, a salmonelose pode ser bastante grave, já que o microrganismo pode atingir a corrente circulatória e provocar lesões em outros órgãos. No adulto, algumas patologias, quando presentes, podem agravar a doença (Franco \& Landgraf, 1996; Jay, 2000).

Hoje em dia as doenças causadas por Salmonella Typhi e Paratyphi são raras por causa dos sistemas de pasteurização do leite e tratamento de água (El-gazzar \& Marth, 1992; Tietjen \& Fung, 1995). Mas salmonelas não tifóides são comuns em alimentos até em países desenvolvidos (Bean et al., 1997; CDC, 1999, 2001; Radkowski, 2002; Hu \& Kopecko, 2003).

Segundo a Organização Pan-Americana de Saúde, as doenças causadas por alimentos (DTAs) nos países latino-americanos entre 1993 e 2002 totalizaram 6.511 surtos, com 232.576 pessoas afetadas e 317 falecimentos. Segundo o SIRVETA (Sistema de Informacion para la Vigilancia de las Enfermidades Transmitidas por los Alimentos), as bactérias foram responsáveis por $57,05 \%$ destes surtos, sendo as salmonelas responsáveis por 871 surtos, 42.144 afetados e 15 mortes. Já no Brasil (Quadro 1), no mesmo período, foram 645 surtos, com 18.950 pessoas afetadas e 5 mortes, sendo que Salmonella foi responsável por 222 surtos, com 10.977 pessoas afetadas e 3 mortes (SIRVETA, 2004).

No Brasil, os ovos e seus derivados, principalmente a maionese caseira, são os principais responsáveis pelos surtos humanos envolvendo Salmonella (Silva \& Duarte, 2002). 
Quadro 1. Alimentos envolvidos nos casos de DTAs por Salmonella no Brasil, no ano de 1993 a 2002 (SIRVETA, 2004).

\begin{tabular}{|c|c|c|c|c|c|c|}
\hline \multirow{3}{*}{$\begin{array}{l}\text { Alimentos } \\
\text { envolvido } \\
\text { OVO-MAIONESE }\end{array}$} & \multicolumn{2}{|c|}{ Surtos } & \multicolumn{2}{|c|}{ Afetados } & \multirow{2}{*}{$\begin{array}{c}\text { Doentes } \\
\text { Número }(\%)\end{array}$} & \multirow{2}{*}{$\begin{array}{c}\text { Mortes } \\
\text { Número (\%) }\end{array}$} \\
\hline & \multicolumn{2}{|c|}{ Número $(\%)$} & \multicolumn{2}{|c|}{ Número $(\%)$} & & \\
\hline & 152 & 88.47 & 3287 & 75.49 & $8286 \quad 75.51$ & $1 \quad 33.33$ \\
\hline OUTROS & 18 & 8.11 & 763 & 6.95 & $762 \_6.94$ & $1 \ldots 33.33$ \\
\hline CARNES VERMELHA & & -4.95 & 690 & 6.29 & $690 \quad 6.29$ & $0 \ldots 00$ \\
\hline MISTOS & 10 & 4.50 & 356 & 3.24 & $356 \quad 3.24$ & $0 \quad 0.00$ \\
\hline FARINÁCEOS & 9 & 4.05 & 199 & 1.81 & $199 \quad 1.81$ & $0 \_0.00$ \\
\hline CARNE DE AVES & 9 & 4.05 & 120 & 1.09 & $120 \quad 1.09$ & $0 \quad 0.00$ \\
\hline PESCADOS & 3 & 1.35 & 174 & 1.59 & $174 \_1.59$ & $0 \quad 0.00$ \\
\hline $\begin{array}{l}\text { HORTALICYAS- } \\
\text { LEGUMES }\end{array}$ & & 1.35 & 263 & 2.40 & $262 \_2.39$ & $1 \ldots 33.33$ \\
\hline ÁGUA & & 1.35 & & 0.65 & $71 \_0.65$ & $0 \ldots \quad 0.00$ \\
\hline SOAREMESAS & & 0.90 & 27 & 0.25 & $27 \quad 0.25$ & 0.0 .00 \\
\hline LACTEOS & & 0.90 & & 0.25 & $27 \_0.25$ & $0 \_0.00$ \\
\hline WTAL & & & & & $105: 4$ & 3 \\
\hline
\end{tabular}

Os dados do SIRVETA são, entretanto, incompletos. Segundo a Divisão de Doenças de Transmissão Hídrica e Alimentar - CVE, da Secretaria Estadual de Saúde de São Paulo, somente no Estado de São Paulo ocorreram, em 2001, 392 surtos, sendo Salmonella responsável por 44 deles, com 671 afetados e nenhuma morte. Ainda segundo essa fonte, em 2002, ocorreram 302 surtos, sendo Salmonella responsável por 31 surtos com 292 afetados e nenhum óbito (CVE, 2001; 2002).

Nos últimos anos tem havido um grande aumento no surto de salmonelose em muitos países. Muitos destes surtos estão associados ao consumo de ovos crus ou mal cozidos contaminados por $S$. Enteritidis, ou por alimentos contendo ovos crus em sua composição (Dreesen et al., 1992; Palumbo et al., 1995; Altekruse et al, 1997; D'Aoust, 1997; ICMSF, 1998; Radkowski, 2002; Hanes, 2003). 
Em 2000, Ebel e Schlosser desenvolveram um modelo matemático no qual estimaram que nos Estados Unidos existe um ovo contaminado com Salmonella Enteritidis para cada 20.000 ovos produzidos. Assumindo-se que nesse país são produzidos aproximadamente 65 bilhões de ovos por ano, pode-se estimar que aproximadamente 3,2 milhões de ovos produzidos por ano nos Estados Unidos estão contaminados com Salmonella Enteritidis.

Quanto aos ovos desidratados, diversos surtos de salmonelose já foram relatados, tanto pela ingestão direta do microrganismo em alimentos preparados com esse produto quanto por contaminação cruzada nos locais de preparação (ICMSF, 1998). Nos Estados Unidos, já em 1947, Solowey et al. haviam observado que, de 5198 amostras de ovo integrais desidratadas analisadas, 1810 (35\%) estavam contaminadas por Salmonella, sendo que muitas das cepas isoladas eram as mais comuns em surtos de salmonelose. Estes autores observaram ainda que a casca era a fonte mais importante de contaminação dos ovos em pó.

Potencialmente, Salmonella pode permanecer viva por longo tempo em ovos desidratados, embora não seja capaz de se multiplicar. Embora a atividade de água mínima para multiplicação de Salmonella seja 0,93, esse patógeno é capaz de sobreviver por longo tempo em produtos desidratados com Aa inferiores a esse limite (D'Aoust, 1997). Alguns autores observaram que a sobrevivência é tanto maior quanto menor for a Atividade de Água (Juven et al., 1984; Archer et al., 1998; Jung \& Beuchat, 1999), enquanto outros observaram o oposto (Licari \& Potter, 1970; Christian \& Stewart, 1973). Embora alguns microrganismos sejam destruídos no processo de desidratação, este não é por si só letal (Delazari, 1979; Bergquist, 1986; Carvalho et al., 1994; Abushelaibi et al., 2003).

Para eliminar o risco representado por Salmonella em ovos desidratados, a pasteurização dos ovos líquidos antes da desidratação é imprescindível. A temperatura de coagulação da albumina não permite o emprego de altas temperaturas para pasteurização de ovos, mesmo que as mesmas sejam estabilizadas antes do tratamento térmico. Entretanto, com a utilização da combinação correta de tempo e temperatura e de matéria-prima de boa qualidade, bem como manuseio adequado durante o processamento, Salmonella não deve ser encontrada em ovos desidratados (Delazari, 1979; Dias, Ajzental \& Calil, 2002).

Antes da desidratação, os ovos são submetidos aos seguintes procedimentos: lavagem, ovoscopia, quebra e separação, filtragem e/ou clarificação, padronização (para que se tenha sempre a mesma proporção entre gema e clara), resfriamento e pasteurização. Após a pasteurização, a clara do ovo é ainda submetida a uma etapa denominada estabilização, que corresponde à remoção da glicose, que pode interagir com proteínas e fosfolípides do ovo prejudicando a qualidade final do produto desidratado(Aguirre et al., 1979). A estabilização 
pode ser feita de duas maneiras. Na primeira, a clara é submetida à fermentação microbiana através do uso de microrganismos específicos, que provocam a fermantação da glicose transformando-a em ácido glicônico (para isto ocorrer o $\mathrm{pH}$ deve ser ajustado entre 7 e 7,5). A segunda maneira é através de processo enzimático, empregando-se duas enzimas, glicoseoxidase e catalase, e peróxido de hidrogênio. A estabilização é necessária para se evitar as reações de escurecimento não-enzimático que podem surgir durante tratamentos térmico e o armazenamento do produto (Pereda et al., 2005). A filtragem e/ou clarificação são empregadas para remoção das membranas, pedaços de casca e das chalazas, que são estruturas de sustentação da gema. A padronização é feita para que o ovo integral tenha $65 \%$ de clara e $35 \%$ de gema, com sólidos entre 24 e $25 \%$. O teor de sólidos na gema é 44 a $45 \%$ e na clara, 12 a $13 \%$. A pasteurização é feita entre $57^{\circ} \mathrm{C}$ e $66^{\circ} \mathrm{C}$ por aproximadamente 3,5 minutos. A secagem é feita em spray-drier de torre. De cada $1000 \mathrm{~kg}$ de ovo in natura, obtém-se $213 \mathrm{~kg}$ de ovo integral desidratado, sendo $72 \mathrm{~kg}$ de clara em pó e $158 \mathrm{~kg}$ de gema em pó. O teor de umidade destes produtos é 3-4\%. Os produtos desidratados são embalados em sacos de polietileno atóxico e papel kraft multifolhado. A vida de prateleira é de 6 meses, quando armazenados em local fresco, arejado e isento de insetos e roedores (Barretto, 2001).

Todas as etapas do processo de fabricação do ovo em pó devem ser cuidadosamente monitoradas e controladas, para que não haja alteração das propriedades funcionais da clara e da gema do ovo, a fim de que possam ser utilizadas satisfatoriamente aos fins desejados.

O processo de desidratação do ovo está apresentado na Figura 1.

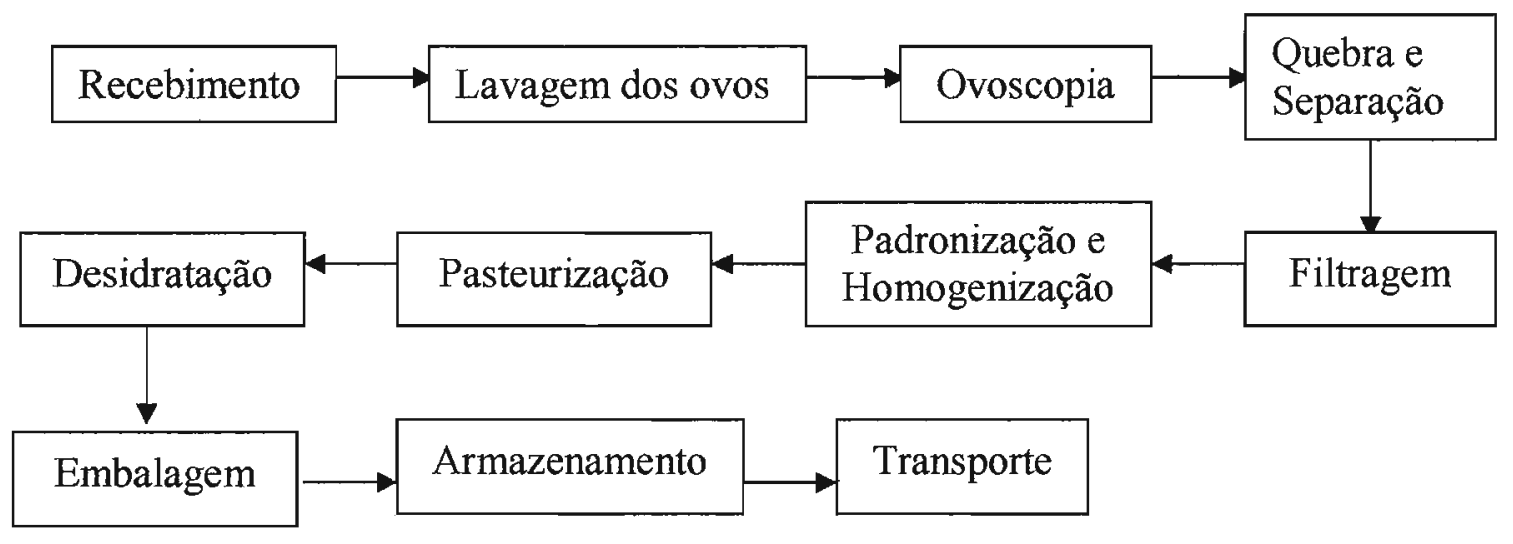

Figura 1. Fluxograma resumido do processo de desidratação do ovo. Fonte: Kayatonas Indústria e Comércio Ltda. 
A presença de salmonela em ovos pasteurizados desidratados é conseqüência de uma pasteurização inadequada de ovos previamente contaminados com este patógeno ou de contaminação pós-pasteurização. Um aumento proposital ou acidental do teor de umidade durante a estocagem leva à multiplicação microbiana, oferecendo um sério risco para a saúde do consumidor (ICMSF, 1998; Dias, Ajzental \& Calil, 2002). A capacidade de sobrevivência e de multiplicação deste patógeno em ovos desidratados (claras, gemas ou ovo integral) é diferente da que se observa em ovos inteiros. Alguns estudos recentes, simulando o período entre a ovoposição e o equilibrio da temperatura interna do ovo, mostraram que $S$. Enteritidis multiplica-se bem e rapidamente na gema do ovo a $25^{\circ} \mathrm{C}$ em 2-3 dias, mas multiplica-se muito devagar na clara (Gast-Richard \& Holt-Peter, 2000). Em ovos desidratados, a multiplicação de Salmonella depende da atividade dos agentes antimicrobianos naturalmente presentes nos ovos que ainda permaneçam ativos após as etapas de processamento tecnológico, da Atividade de Água do produto desidratado e da temperatura de armazenamento.

Com relação à Atividade de Água, estudos realizados ainda na década de 60 mostraram que a adição de 10 a $15 \%$ de sal a gemas mantidas a $12^{\circ} \mathrm{C}$ e $22^{\circ} \mathrm{C}$ resultava no mesmo efeito que a conservação das gemas a $4^{\circ} \mathrm{C}$, ou seja, inibição da multiplicação de Salmonella (Banwart, 1964). Em estudo realizado por Cotteril \& Glaubert, 1972, Salmonella Oranienburg foi inoculada em gema de ovo líquida contendo diferentes concentrações de cloreto de sódio $(10,14,18,22,25$ e $35 \%)$ e armazenada a $-25^{\circ} \mathrm{C}, 16^{\circ} \mathrm{C}, 25^{\circ} \mathrm{C}$ e $36^{\circ} \mathrm{C}$. O isolamento de Salmonella na gema de ovo foi possível durante 28 semanas a $-25^{\circ} \mathrm{C}$, durante 4 a 13 semanas à temperatura de $25^{\circ} \mathrm{C}$ e 1 a 3 semanas a $36^{\circ} \mathrm{C}$.

Em relação à sobrevivência de Salmonella em ovos desidratados, Jung \& Beuchat, 1999 , observaram que a $13^{\circ} \mathrm{C} S$. Typhimurium era completamente inativada quando a Atividade de Água estava entre 0,29 e 0,37. No entanto, foi verificado que a sobrevivência de $S$. Typhimurium a $13^{\circ} \mathrm{C}$ era maior que a $37^{\circ} \mathrm{C}$. Verificou-se também que a $13^{\circ} \mathrm{C}$ a manutenção da viabilidade celular foi maior em Aa entre 0,51 e 0,61 do que entre 0,29 e 0,37. A inativação do patógeno foi mais rápida em clara de ovo desidratada suplementada com xarope de milho ou com sal de forma a resultar em Aa entre 0,51 e 0,61 , armazenada a $37^{\circ} \mathrm{C}$. Esses autores concluíram que, dependendo do nível de contaminação inicial, a pasteurização e posterior desidratação de ovos podem não ser suficientes para garantir a total ausência de Salmonella nestes produtos.

Uma característica preocupante das cepas de Salmonella isoladas de alimentos nos últimos anos é o surgimento de linhagens resistentes aos antibióticos utilizados na prática médica e veterinária (D’Aoust, 1989, 1997; Hanes, 2003). No Brasil, Pereira et al., 1989, 
detectaram que quase $90 \%$ das cepas de Salmonella isoladas de amostras de lingüiça frescal eram resistentes à tetraciclina, $61 \%$ à cefalotina e 58\% à neomicina. Reis et al., 1995, observaram que $100 \%$ das cepas de Salmonella sp. em produtos cárneos crus e processados mostraram-se resistentes a rifampicina, $97,2 \%$ à tetraciclina, $94,4 \%$ à estreptomicina e $86,1 \%$ a ampicilina. Ao analisar surtos alimentares por Salmonella Enteritidis associados ao consumo de alimentos à base de ovos, Araújo et al., 1995, verificaram que todas as cepas isoladas eram resistentes ao sulfazotrim. Tais fatos foram creditados ao uso indiscriminado de antimicrobianos para o controle de enfermidades dos animais.

A relação entre a resistência a essas drogas e uma provável resistência de Salmonella a agentes físicos de conservação de alimentos ainda não está suficientemente estudada. Conhece-se apenas o trabalho de Jung \& Beuchat, 1999, que observaram que, em ovos desidratados, uma mistura de cepas de $S$. Typhimurium DT 104, resistentes a ampicilina, cloranfenicol, estreptomicina, sulfonamidas e tetraciclina apresentou o mesmo comportamento em relação à baixa temperatura e Atividade de Água que outras cepas de $S$. Typhimurium.

Segundo Mañas et al. (2003), Salmonella pode sobreviver à pasteurização. Estes autores estudaram uma cepa de Salmonella Senftenberg $775 \mathrm{~W}$ em ovo líquido integral pasteurizado. A pasteurização industrial de ovo líquido integral a $60^{\circ} \mathrm{C}$ por 3,5 minutos, a $64^{\circ} \mathrm{C}$ por 2,5 minutos e a $70^{\circ} \mathrm{C}$ por 1,5 minutos apenas reduz respectivamente $<1,<2$ e $<4$ ciclos logarítmicos de Salmonella Senfterberg 775W. Doyle \& Mazzotta, em 2000, em um trabalho de revisão, relataram que de todos os valores D reportados, a maior resistência ao calor suportado por Salmonella foi em ovos líquidos e em gema líquida. Estes autores afirmaram que, neste caso, em um processamento a $71^{\circ} \mathrm{C}$ são necessários 1,2 segundos para inativar $1 \log$ de Salmonella. O valor D corresponde ao tempo, em minutos, em uma dada temperatura, necessário para a redução de $90 \%$ no número de células ou esporos presentes em uma suspensão (Franco \& Landgraf, 1996).

Salmonella pode estar presente no ovo em pó, tanto devido à sua capacidade de sobreviver ao processo de pasteurização e desidratação, como através da contaminação após o processamento. Como a pasteurização pode alterar os fatores intrínsecos antimicrobianos presentes no ovo pela desnaturação de proteínas, uma contaminação pós-processamento pode representar um sério risco à saúde humana.

Os resultados encontrados na literatura não são claros com relação à capacidade de Salmonella sobreviver ou mesmo se multiplicar em ovo desidratado, durante o armazenamento inadequado. Esse trabalho foi proposto para preencher essa lacuna, 
monitorando-se a cinética de multiplicação de Salmonella em ovo em pó com diferentes valores de Aa, armazenado por 2 meses em quatro diferentes temperaturas. 


\section{Objetivos}

Este trabalho teve como objetivo avaliar a capacidade de Salmonella Enteritidis sobreviver ou se multiplicar em ovo em pó, em função de sua Atividade de Água (Aa) e temperatura de armazenamento. Para isso, foram preparadas amostras de ovo em pó com diferentes valores de $\mathrm{Aa}(0,4,0,6,0,8$ e 0,9), que foram experimentalmente contaminadas com Salmonella Enteritidis e armazenadas em quatro temperaturas diferentes $\left(8^{\circ} \mathrm{C}, 15^{\circ} \mathrm{C}, 25^{\circ} \mathrm{C} \mathrm{e} 35^{\circ} \mathrm{C}\right)$ por até 8 semanas. O estudo objetivou também observar se uma cepa de Salmonella resistente a antibióticos apresentava cinética de multiplicação diferente daquela observada para a cepa não resistente. 


\section{Materiais e Métodos}

\subsection{Materiais:}

Microrganismos: Salmonella Enteritidis FBM01, sensível aos antibióticos comumente utilizados na prática médica e Salmonella Hadar resistente aos antibióticos Ampicilina, SXT (Sulfazotrim e Trimetropim), Amoxilina, Trimetropim, Sulfazotrim, Sulfisoxozole e Estreptomicina. As duas cepas foram isoladas por Fuzihara et al., 2000.

Ovo desidratado: ovo em pó integral, doado pela empresa Kayatonas Indústria e Comércio Ltda, localizada no município de Biritiba-Mirim, SP.

\subsection{Métodos:}

\subsubsection{Manutenção da cultura de Salmonella}

As cepas de Salmonella foram inoculadas em tubos com agar tripticase soja (TSA Oxoid, Basingstoke, UK ) e incubadas a $35^{\circ} \mathrm{C}$ por $24 \mathrm{~h}$. A partir desse tubo, foram semeados outros tubos contendo ágar conservação (Extrato de Carne $3 \mathrm{~g} / 1$, Peptona $10 \mathrm{~g} / 1$, Cloreto de Sódio $8 \mathrm{~g} / \mathrm{l}$, Fosfato de Sódio Dibásico $1,2 \mathrm{~g} / 1$ e Agar $15 \mathrm{~g} / \mathrm{l}$ ) inclinado, os quais foram incubados a $35^{\circ} \mathrm{C}$ por $24 \mathrm{~h}$. Após a incubação, as culturas foram mantidas sob refrigeração a $4^{\circ} \mathrm{C}$.

\subsubsection{Padronização do inóculo de Salmonella}

Com auxílio de uma alça de níquel-cromo, transferiu-se uma alíquota da cultura no ágar conservação para um tubo contendo $10 \mathrm{ml}$ de Caldo Tripticase Soja (TSB), que foi incubado por $24 \mathrm{~h}$ a $35^{\circ} \mathrm{C}$. Após este período, $1 \mathrm{ml}$ do caldo foi transferido para um frasco erlenmeyer contendo $100 \mathrm{ml}$ de caldo TSB, que foi incubado a $35^{\circ} \mathrm{C}$. A cada uma hora, nas 
duas primeiras horas e a cada meia hora, nas horas seguintes, retirou-se $5 \mathrm{ml}$ do caldo no erlenmeyer para avaliação da densidade óptica em comprimento de onda de $640 \mathrm{~nm}$, em espectrofotômetro (Pharmacia Biotech Ultrospec 2000 UV/Visible Spectrophotometer). Simultaneamente, e em duplicata, $0,1 \mathrm{ml}$ do caldo e das diluições decimais desse caldo, preparadas em solução salina estéril a $0,85 \%$ foram semeados em superfície em placas de agar TSA e incubadas a $35^{\circ} \mathrm{C}$ por $24 \mathrm{~h}$. Após a incubação, selecionaram-se as placas com 25 a 250 colônias, fazendo-se a contagem. Calculou-se a média das duplicatas e determinou-se o número de $\mathrm{UFC} / \mathrm{ml}$ de caldo, multiplicando-se essa média pelo inverso da diluição correspondente.

\subsubsection{Preparo do ovo para inoculação experimental}

A fim de se estabelecer a quantidade de água a ser adicionada ao ovo em pó, de modo a conseguir-se os valores de atividade de água (Aa) desejados, construiu-se uma curva de calibração, adicionando-se quantidades variáveis de água destilada ao ovo desidratado e determinando-se assim a Aa. A curva foi iniciada com adição de 1\% de água, aumentando-se a concentração até $30 \%$, com intervalos de 1\%. A determinação de Aa foi realizada em temperatura controlada de $25^{\circ} \mathrm{C}$. A Aa foi medida utilizando-se o aparelho Novasina Awcenter 503-C, Axair AG, Pfäffikon, Switzerland (Novasina AG, Zurich, Suíça).

\subsubsection{Inoculação experimental do ovo em pó}

De acordo com os resultados obtidos no item 3.2.3., calculou-se as quantidades de ovo em pó e de água destilada necessárias para se obter $10 \mathrm{~g}$ do produto com a Aa desejada. Em seguida, transferiu-se a quantidade necessária de ovo para um saco plástico Whirl-Pak (Saco plástico Estéril de Polietileno para coleta de amostras até $300 \mathrm{ml}$, Millipore, Nasco) e adicionou-se a quantidade de água destilada estéril, massageando-se manualmente o saco durante alguns minutos até completa homogeneização. Obtida a melhor homogeneização possível, adicionou-se à mistura $100 \mu \mathrm{l}$ da cultura de Salmonella, diluída em solução salina $0,85 \%$ de forma a obter $10^{6} \mathrm{UFC} / \mathrm{g}$. A concentração final de Salmonella no ovo era de $10^{4}$ UFC/g de produto. O saco foi novamente massageado para a melhor distribuição possível do inóculo no produto. Para cada experimento foram preparados 160 sacos, que foram divididos 
em quatro lotes de 40 sacos, para incubação a $8^{\circ} \mathrm{C}, 15^{\circ} \mathrm{C}, 25^{\circ} \mathrm{C}$ e $35^{\circ} \mathrm{C}$. Para cada lote de 40 sacos, 24 foram empregados para contagem de Salmonella ( $3 \times 8$ sacos) em triplicatas semanais, 8 correspondiam aos controles negativos e 8 foram empregados para medida da Aa. Após a adição de água e da cultura da Salmonella, ou somente de água (controles), os sacos foram selados com o auxílio de uma seladora Barbi modelo M-300. Para evitar perda de umidade para o ambiente e conseqüente redução no valor da $\mathrm{Aa}$, influenciando na cinética de multiplicação de Salmonella, os sacos Whirl-Pak com ovo com Aa 0,8 e 0,93 foram embalados novamente em sacos Cryovac BB-200 (Sacos Barrier Bag com estrutura EVA multicamadas, CRYOVAC do Brasil Ltda - Sealed Air Corporation, São Paulo - S.P.) impermeáveis ao vapor de água.

A fim de eliminar a influência da microbiota autóctone na cinética de multiplicação de Salmonella, as amostras de ovo destinadas aos experimentos com Aa 0,8 e 0,9, foram submetidas à irradiação com $3 \mathrm{kGy}$. A irradiação foi feita na empresa EMBRARAD S.A. estabelecida no município de Cotia - SP, empregando-se um irradiador JS 7500 Nordion International Inc., Kanata, Ontário, Canadá, cuja fonte é ${ }^{60} \mathrm{Co}$.

\subsubsection{Armazenamento do ovo experimentalmente contaminado}

As amostras de ovo experimentalmente contaminadas foram armazenadas protegidas da luz, empregando-se um refrigerador para a temperatura de $8^{\circ} \mathrm{C}$ e três estufas BOD para as temperaturas de $15^{\circ} \mathrm{C}, 25^{\circ} \mathrm{C}$ e $35^{\circ} \mathrm{C}$. O tempo de armazenamento estendeu-se até 56 dias, ou seja, 8 semanas, retirando-se semanalmente três amostras inoculadas e duas não inoculadas, para cada uma das quatro temperaturas estudadas. A temperatura de armazenamento das amostras foi monitorada diariamente.

\subsubsection{Enumeração de Salmonella no ovo}

A enumeração de Salmonella nas amostras de ovo experimentalmente contaminado foi feita empregando-se a metodologia descrita por Andrews et al., 1995, baseada na técnica dos tubos múltiplos (Garthright, 1998). A cada saco com 10 gramas de ovo adicionou-se $90 \mathrm{ml}$ de Caldo Lactosado (Oxoid, Basingstoke, UK), homogeneizando-se a mistura com um homogeneizador de pistões (Stomacher 400 Lab Blender, Seward Medical, England), 
obtendo-se assim a diluição $10^{-1}$. A diluição $10^{-2}$ foi obtida transferindo-se $1 \mathrm{ml}$ da diluição $10^{-1}$ para um tubo contendo $9 \mathrm{ml}$ de solução salina $0,85 \%$ e assim por diante para as diluições decimais subsequentes.

Para a enumeração de Salmonella, 3 porções de $10 \mathrm{ml}$ da mistura correspondente à diluição $10^{-1}$ foram transferidas para tubos vazios esterilizados. Simultaneamente, transferiuse 3 porções de $1 \mathrm{ml}$ das demais diluições para 3 tubos contendo $9 \mathrm{ml}$ de Caldo Lactosado. Após a adequada homogeneização através de leve agitação manual, todos os tubos foram incubados a $35^{\circ} \mathrm{C}$ por $24 \mathrm{~h}$.

Em seguida, alíquotas de $0,1 \mathrm{ml}$ de cada um dos tubos de Caldo Lactosado foram transferidas para tubos com $10 \mathrm{ml}$ de Caldo Rappaport-Vassiliadis (RV-Oxoid, Basingstoke, UK). Após homogeneização através de leve agitação manual, os tubos de caldo RV foram incubados a $42^{\circ} \mathrm{C}$ por $24 \mathrm{~h}$. Em seguida, alíquotas do caldo RV foram inoculadas, por esgotamento, na superfície de placas com ágar Xilose Lisina Desoxicolato (XLD - Oxoid, Basingstoke, UK), com o auxilio uma alça de níquel-cromo. As placas foram incubadas a $35^{\circ} \mathrm{C}$ por $24 \mathrm{~h}$ e em seguida observou-se a presença de colônias típicas de Salmonella, ou seja, colônias escuras, de bordos regulares, com ou sem brilho, circundadas por um halo transparente. Uma colônia suspeita de Salmonella por placa foi transferida para um tubo com ágar Tríplice Açúcar Ferro (TSI - Oxoid, Basingstoke, UK) e incubada por a $35^{\circ} \mathrm{C}$ por $24 \mathrm{~h}$. As culturas nos tubos de ágar TSI que apresentaram fundo ácido (amarelo) e base alcalina (vermelho), com ou sem produção de $\mathrm{H}_{2} \mathrm{~S}$ (enegrecimento), foram submetidas à sorologia para confirmação de Salmonella, empregando-se o soro polivalente somático da Probac do Brasil Produtos Bacteriológicos Ltda.

De acordo com o número de tubos positivos entre os três inoculados para cada uma das diluições seriadas, determinou-se o número mais provável de Salmonella por grama de produto, empregando-se para isto, a tabela de Número Mais Provável (NMP), de Garthright, 1998

Este procedimento está apresentado na Figura 2. 


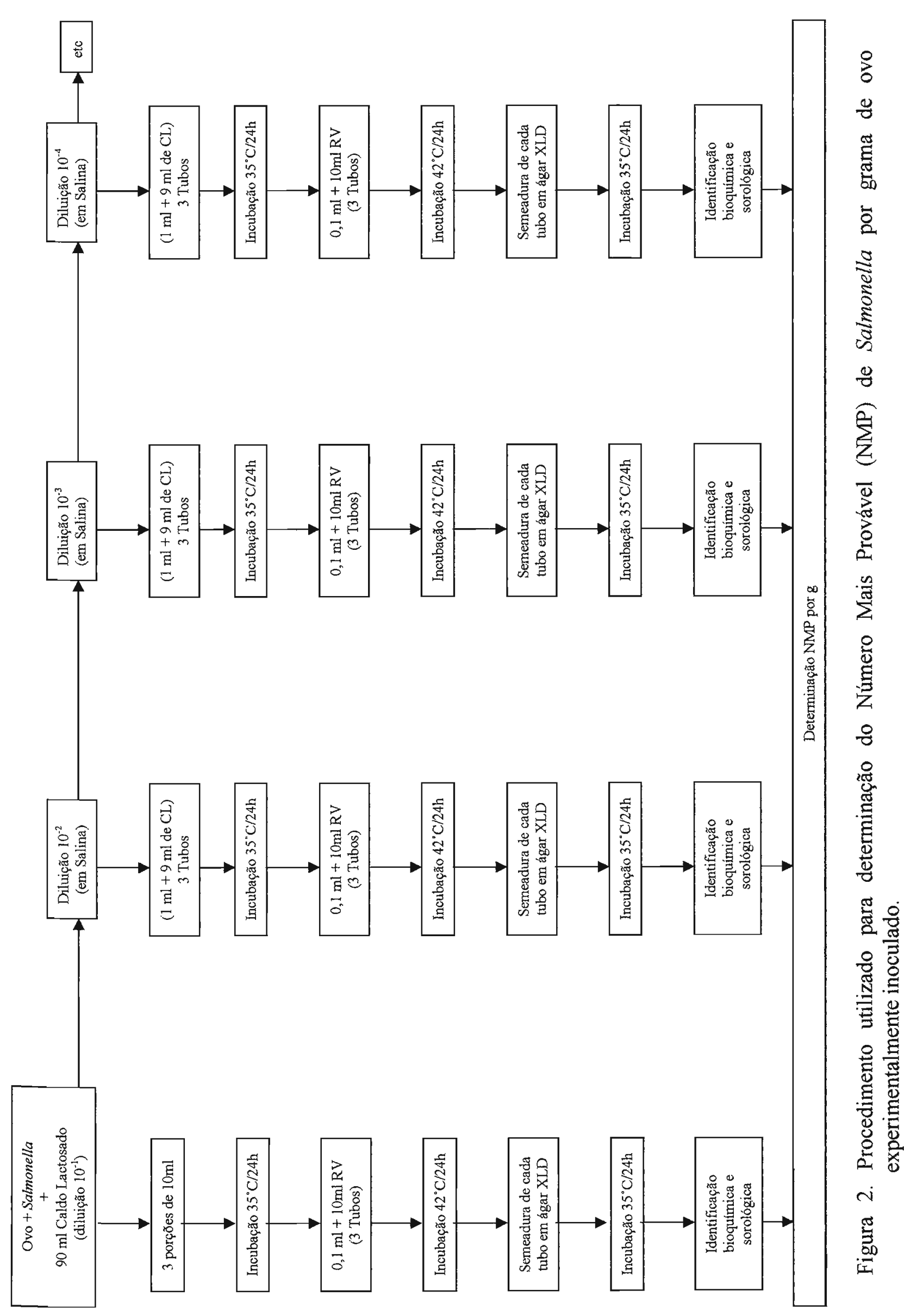




\subsubsection{Contagem total de bactérias aeróbias mesófilas}

Para se monitorar a contaminação das amostras estudadas com bactérias aeróbias mesófilas, utilizou-se, para cada uma das temperaturas testadas, um dos sacos contendo 10 gramas de ovo em pó reconstituído na Aa desejada, não inoculado com Salmonella. O conteúdo do saco foi homogeneizado com $90 \mathrm{ml}$ de solução salina $0,85 \%$, empregando-se o homogeneizador de pistões (Stomacher 400 Lab Blender, Seward Medical, England). Em seguida, foram preparadas diluições decimais seriadas até $10^{-5}$, empregando-se solução salina. Alíquotas de $1 \mathrm{ml}$ de cada uma das diluições foram transferidas para placas estéreis, em duplicatas, às quais se adicionou Agar Plate Count (APC - Oxoid, Basingstoke, UK), homogeneizando-se através de movimentos giratórios. As placas foram incubadas à $37^{\circ} \mathrm{C}$ por 48 horas. Após a incubação, as colônias presentes nas placas apresentando de 25 a 250 colônias foram contadas. Calculou-se a média das duplicatas e determinou-se o número de UFC/g de produto multiplicando-se essa média pelo inverso da diluição correspondente (Maturin \& Peeler, 1998).

\subsubsection{Contagem total de coliformes}

Uma alíquota de $1 \mathrm{ml}$ das diluições $10^{-1}$ e $10^{-2}$, preparadas conforme descrito no item 3.2.7, foi transferida para uma placa estéril, a qual se adicionou Agar Violet Red Bile (VRB Oxoid, Basingstoke, UK), homogeneizando-se através de movimentos giratórios. As placas foram incubadas às $37^{\circ} \mathrm{C}$ por $48 \mathrm{~h}$. Após a incubação, as colônias de coliformes, quando presentes, foram enumeradas, determinando-se o número de UFC/g de produto. As colônias características apresentavam coloração púrpura circundadas por halos púrpura, ou colônias pálidas com zonas esverdeadas (Hitchins et al., 1998).

\subsubsection{Monitoramento da Aa das amostras de ovo}

Em cada uma das retiradas de amostras para contagem de Salmonella, a Aa do ovo foi determinada empregando-se um dos sacos não inoculados. A Aa foi medida empregando-se o 
aparelho Novasina Aw-center 503-C, Axair AG, Pfäffikon, Switzerland (Novasina AG, Zurich, Suiça).

\subsubsection{Analise estatística}

Os dados das variáveis $\mathrm{Aa}$, temperatura e tempo de armazenamento foram submetidas à análise de variância (ANOVA), considerando-se 5\% de probabilidade.

A significância das diferenças nos resultados de contagem de Salmonella nas amostras de ovo em pó com diferentes valores de $\mathrm{Aa}$, para cada uma das quatro temperaturas estudadas foi avaliada através do teste de médias de Duncan, adotando-se $5 \%$ de probabilidade.

$\mathrm{Na}$ comparação dos resultados obtidos para as duas cepas de Salmonella foi utilizado o teste $t$ pareado de Student, com $5 \%$ de probabilidade.

As análises estatísticas foram realizadas empregando-se o SAS (Statistical Analysis Systems) versão 8 . 


\section{Resultados}

O Quadro 2 e a Figura 3 mostram os resultados da curva de calibração, correspondente à relação entre a porcentagem de água adicionada ao ovo e o valor da Aa resultante no produto.

Quadro 2. Relação entre a porcentagem de água adicionada ao ovo desidratado e a Aa resultante

\begin{tabular}{|cc|cc|}
\hline \% de água & \multicolumn{1}{c}{ Aa } & \% de água & Aa \\
\hline 0 & 0,201 & 16 & 0,850 \\
1 & 0,331 & 17 & 0,867 \\
2 & 0,432 & 18 & 0,876 \\
3 & 0,475 & 19 & 0,880 \\
4 & 0,529 & 20 & 0,892 \\
5 & 0,599 & 21 & 0,906 \\
6 & 0,622 & 22 & 0,912 \\
7 & 0,685 & 23 & 0,915 \\
8 & 0,701 & 24 & 0,917 \\
9 & 0,708 & 25 & 0,919 \\
10 & 0,733 & 26 & 0,924 \\
11 & 0,764 & 27 & 0,936 \\
12 & 0,786 & 28 & 0,941 \\
13 & 0,799 & 29 & 0,955 \\
14 & 0,821 & 30 & 0,965 \\
15 & 0,841 & & \\
\hline
\end{tabular}




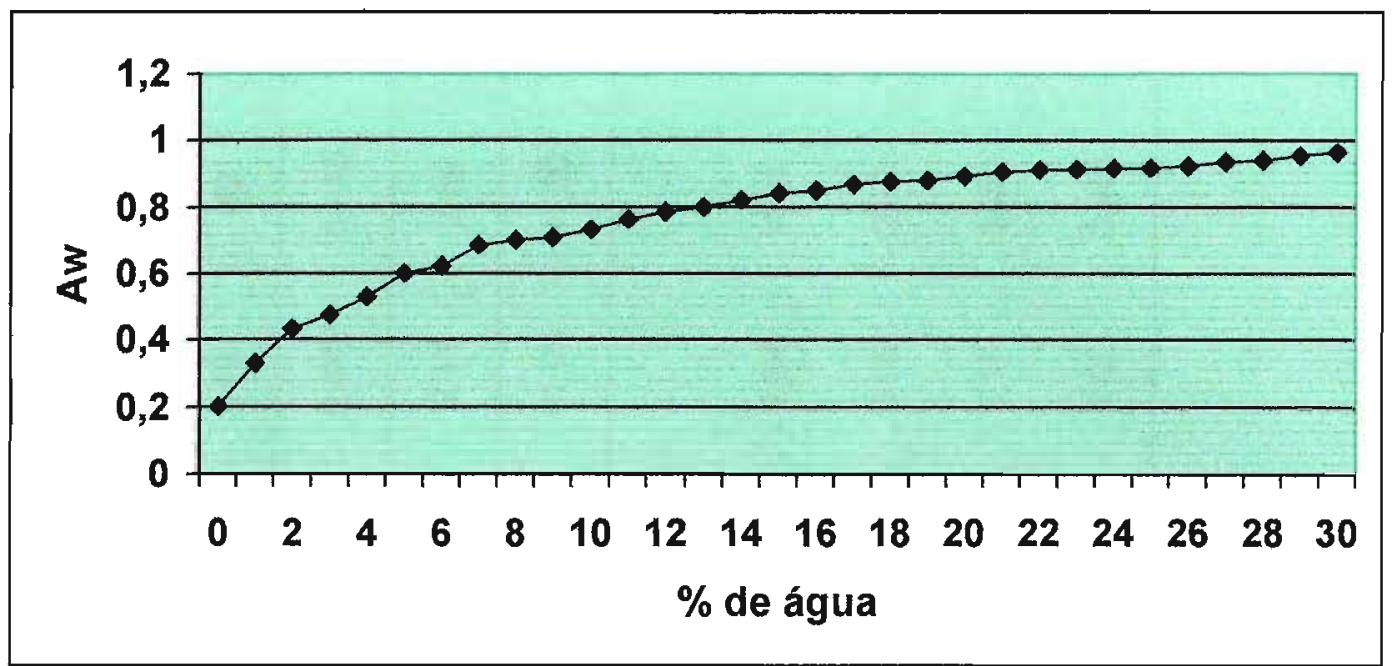

Figura 3. Relação entre a porcentagem de água adicionada ao ovo desidratado e o valor de Aa resultante.

As Tabelas 1, 2, 3 e 4 mostram, respectivamente, os resultados obtidos com o produto com Aa em torno de 0,4 , nas temperaturas de $8^{\circ} \mathrm{C}, 15^{\circ} \mathrm{C}, 25^{\circ} \mathrm{C}$ e $35^{\circ} \mathrm{C}$, referentes à $S$. Enteritidis.

As Tabelas 5, 6, 7 e 8 mostram, respectivamente, os resultados obtidos com o produto com Aa em torno de 0,6 , nas temperaturas de $8^{\circ} \mathrm{C}, 15^{\circ} \mathrm{C}, 25^{\circ} \mathrm{C}$ e $35^{\circ} \mathrm{C}$, referentes à $S$. Enteritidis.

As Tabelas 9, 10, 11 e 12 mostram, respectivamente, os resultados obtidos com o produto com Aa em torno de 0,8 , nas temperaturas de $8^{\circ} \mathrm{C}, 15^{\circ} \mathrm{C}, 25^{\circ} \mathrm{C}$ e $35^{\circ} \mathrm{C}$, referentes à $S$. Enteritidis.

As Tabelas 13, 14, 15 e 16, mostram respectivamente os resultados obtidos com o produto com Aa em torno de 0,9 , nas temperaturas de $8^{\circ} \mathrm{C}, 15^{\circ} \mathrm{C}, 25^{\circ} \mathrm{C}$ e $35^{\circ} \mathrm{C}$, referentes à $S$. Enteritidis.

As Tabelas 17, 18, 19 e 20 mostram, respectivamente, os resultados obtidos com o produto com Aa em torno de 0,6 , nas temperaturas de $8^{\circ} \mathrm{C}, 15^{\circ} \mathrm{C}, 25^{\circ} \mathrm{C}$ e $35^{\circ} \mathrm{C}$, referentes a Salmonella Hadar.

As Tabelas 21, 22, 23 e 24 mostram, respectivamente, os resultados do teste de médias de Duncan para as variáveis Aa e Tempo de armazenamento, nas Aa 0,4, 0,6, 0,8 e 0,9.

Por último, as Tabelas 25 a 32 mostram, respectivamente, os resultados do teste de médias de Duncan para as variáveis Aa e Temperatura de armazenamento, nos dias 7, 14, 21, 28, 35, 42, 49 e 56. 


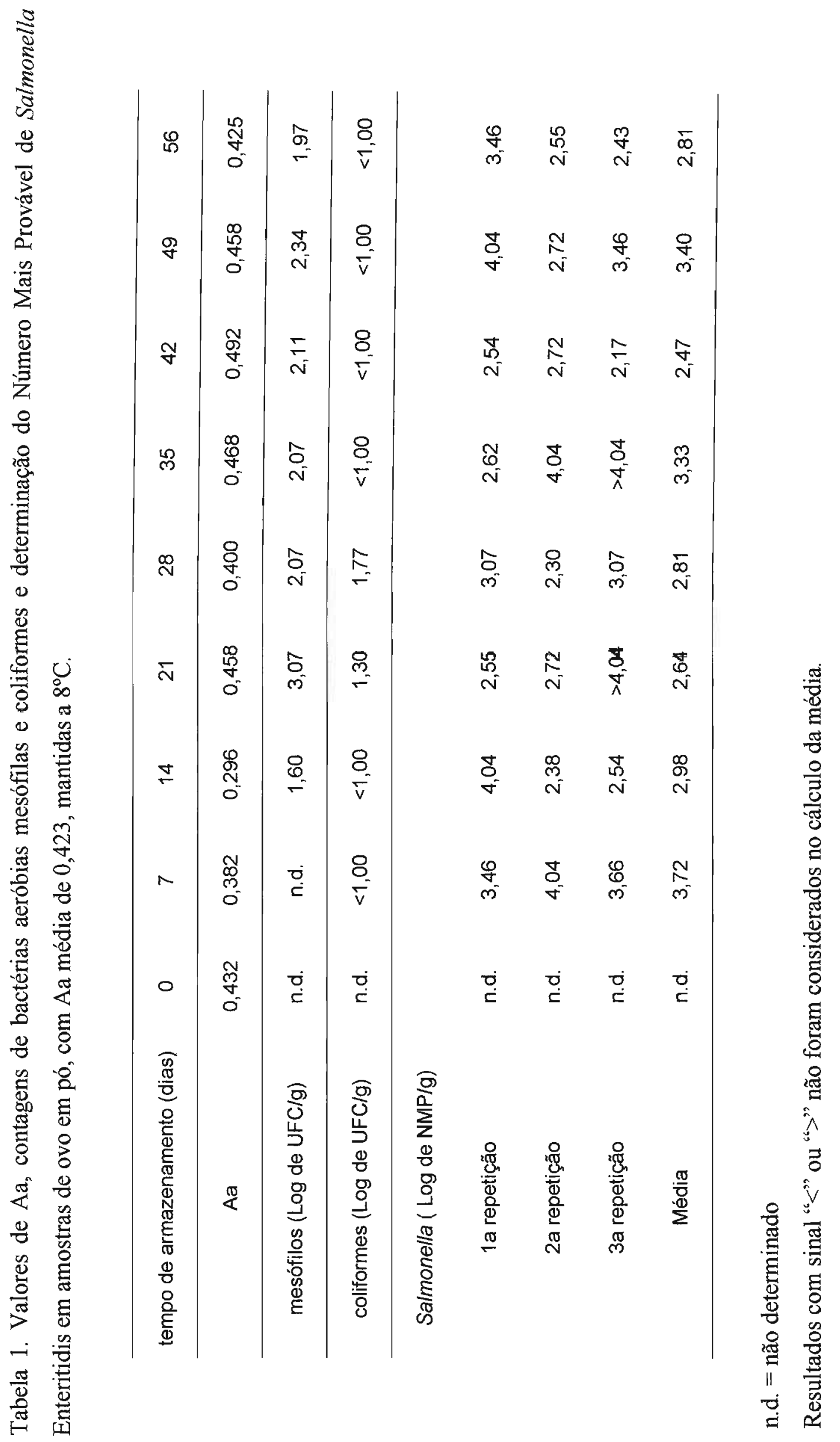




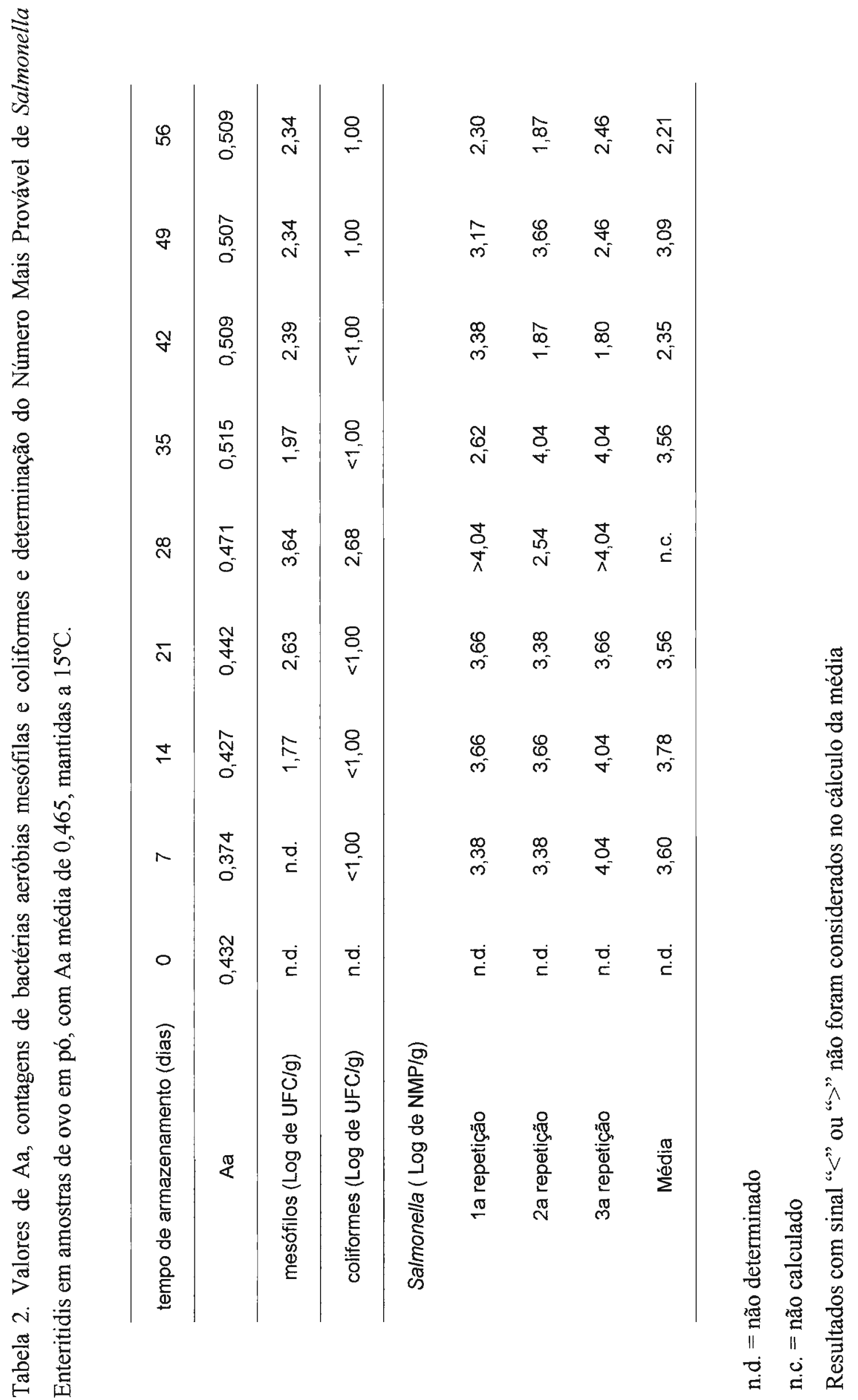




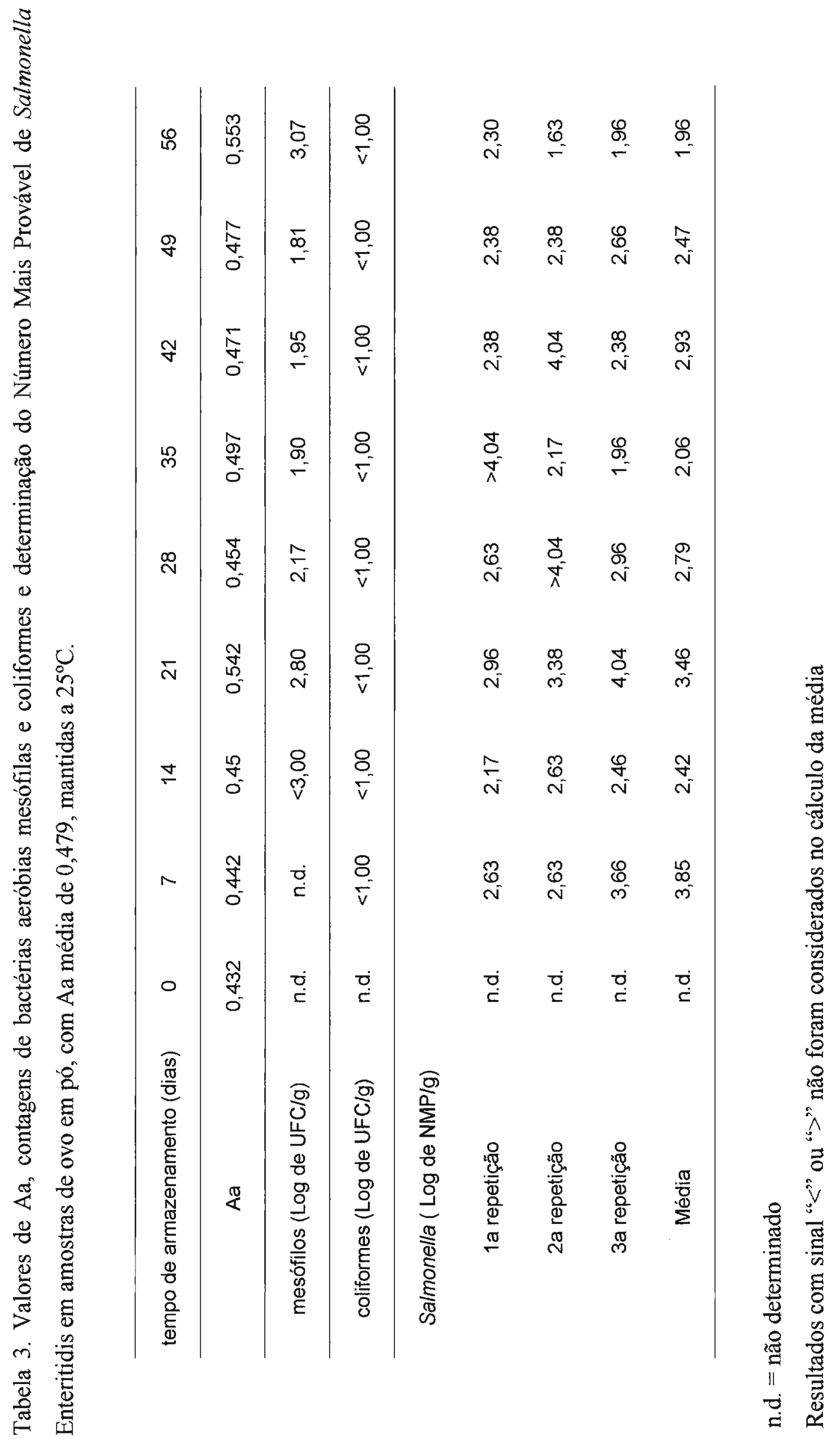




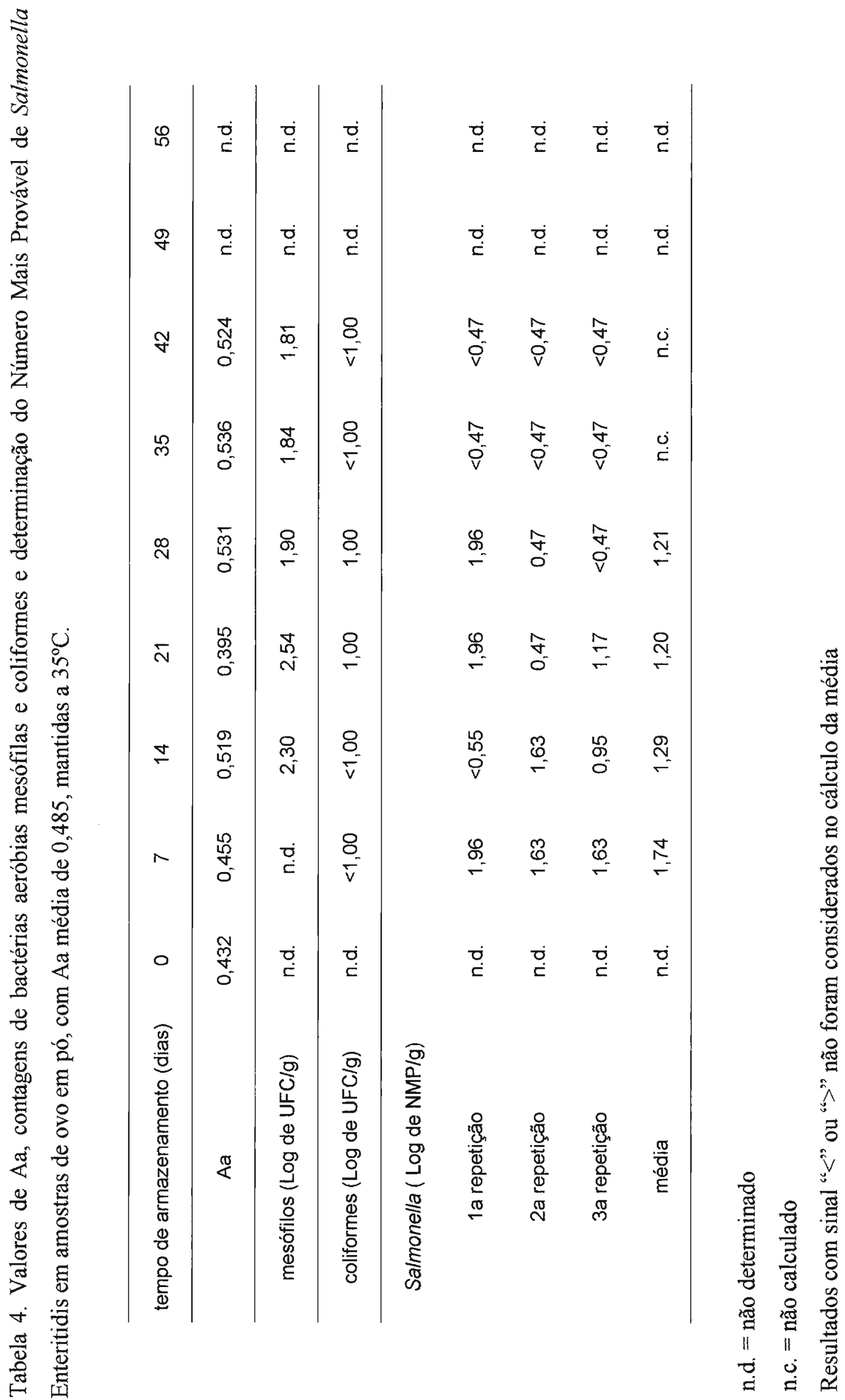




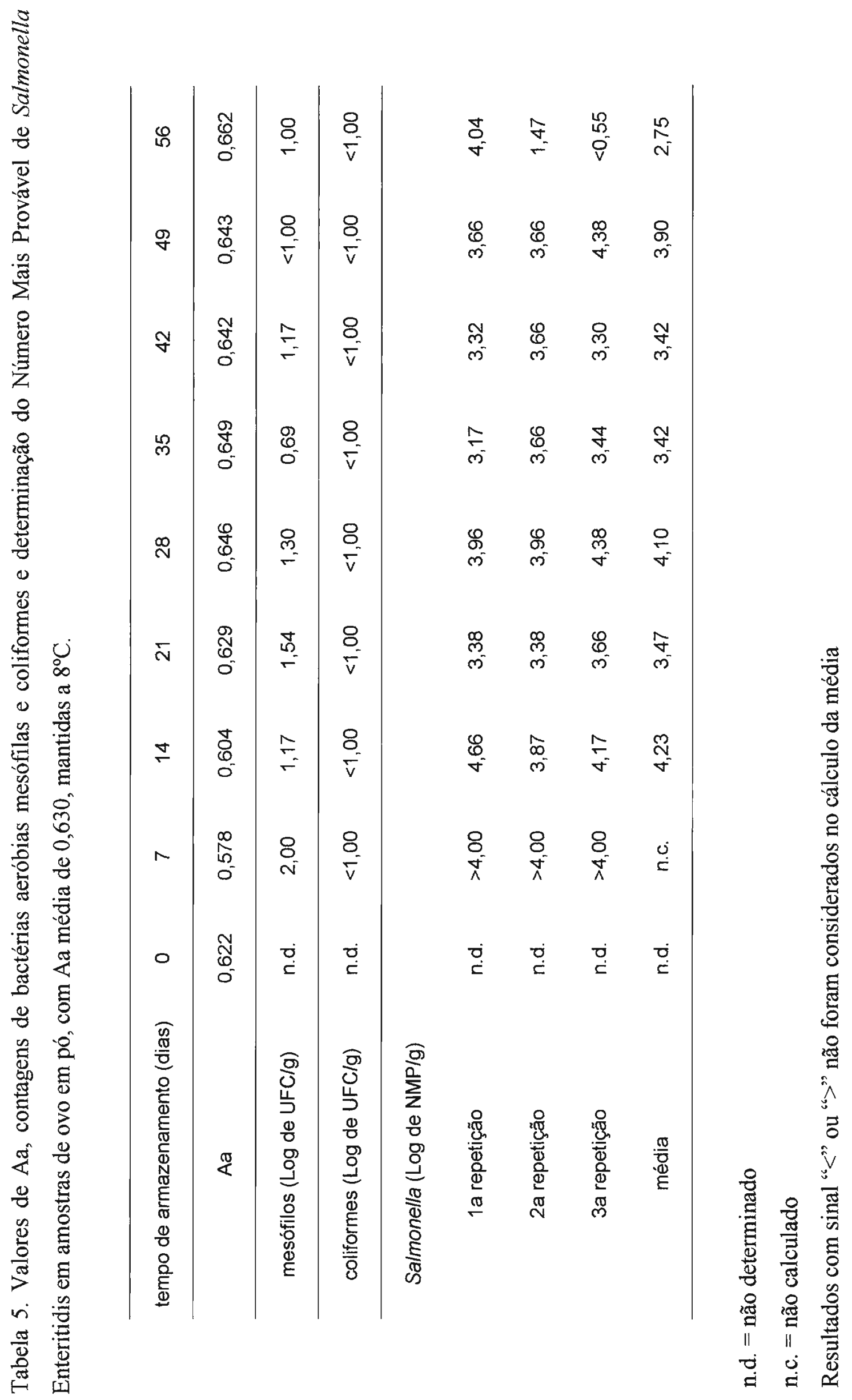




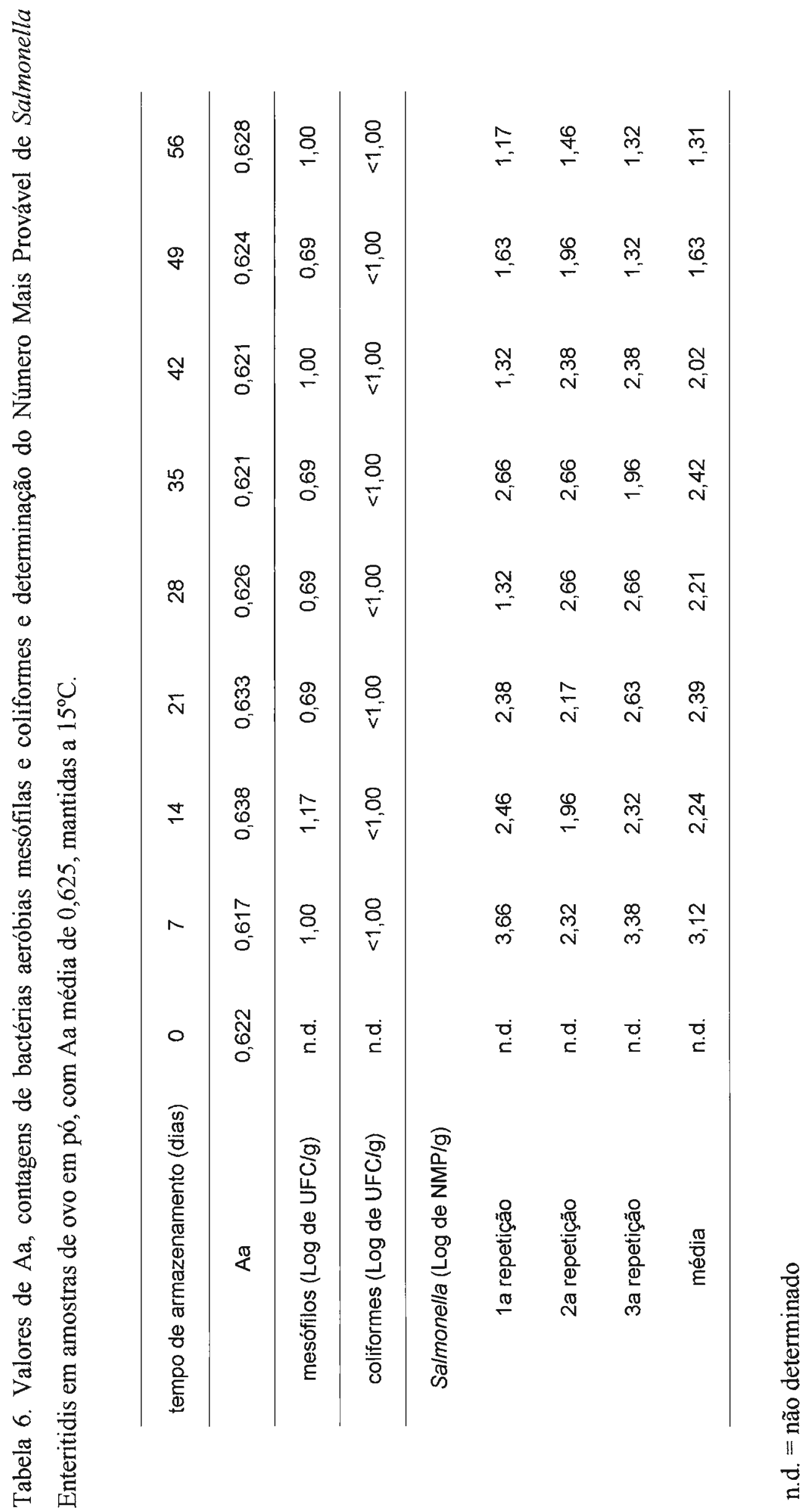




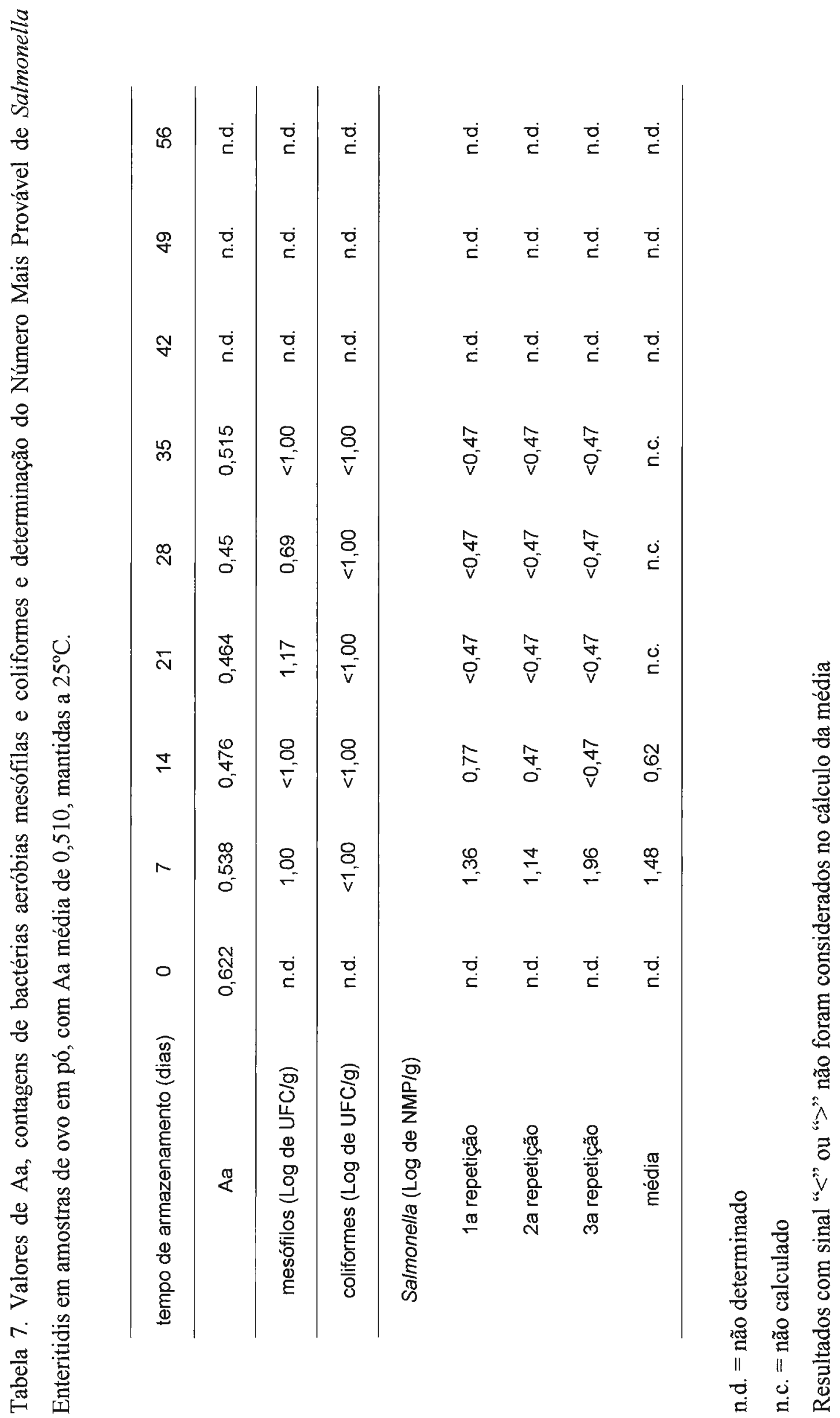




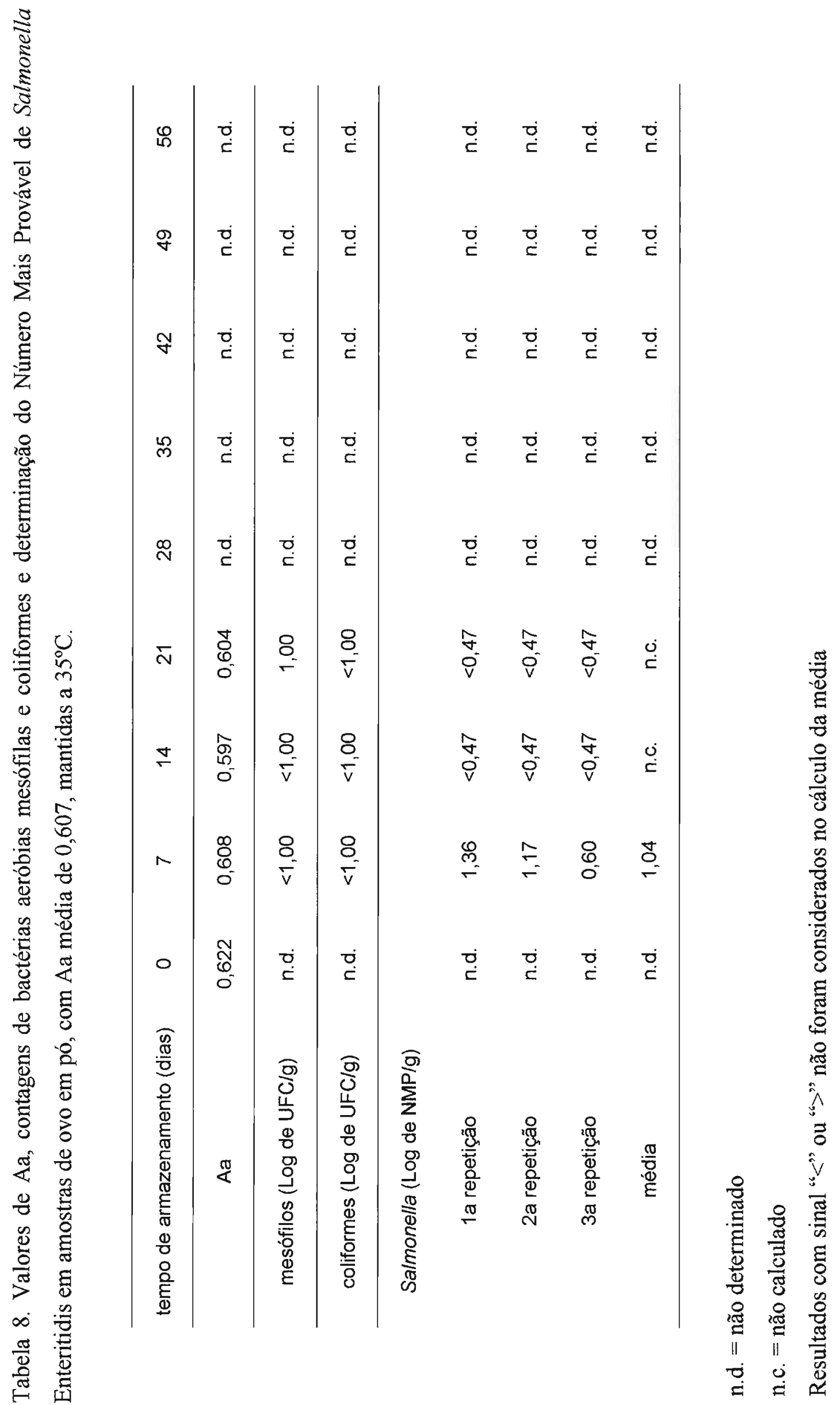




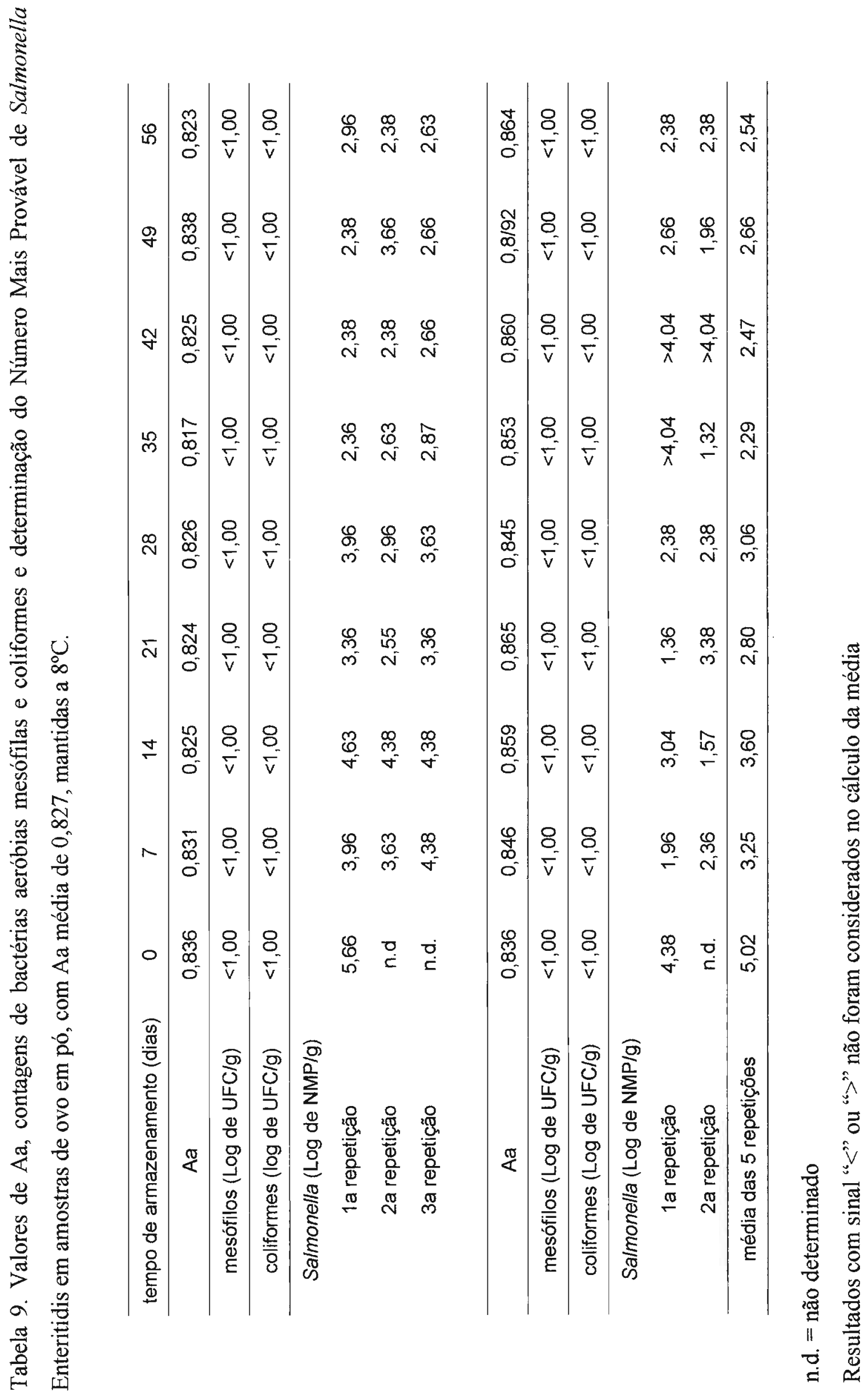




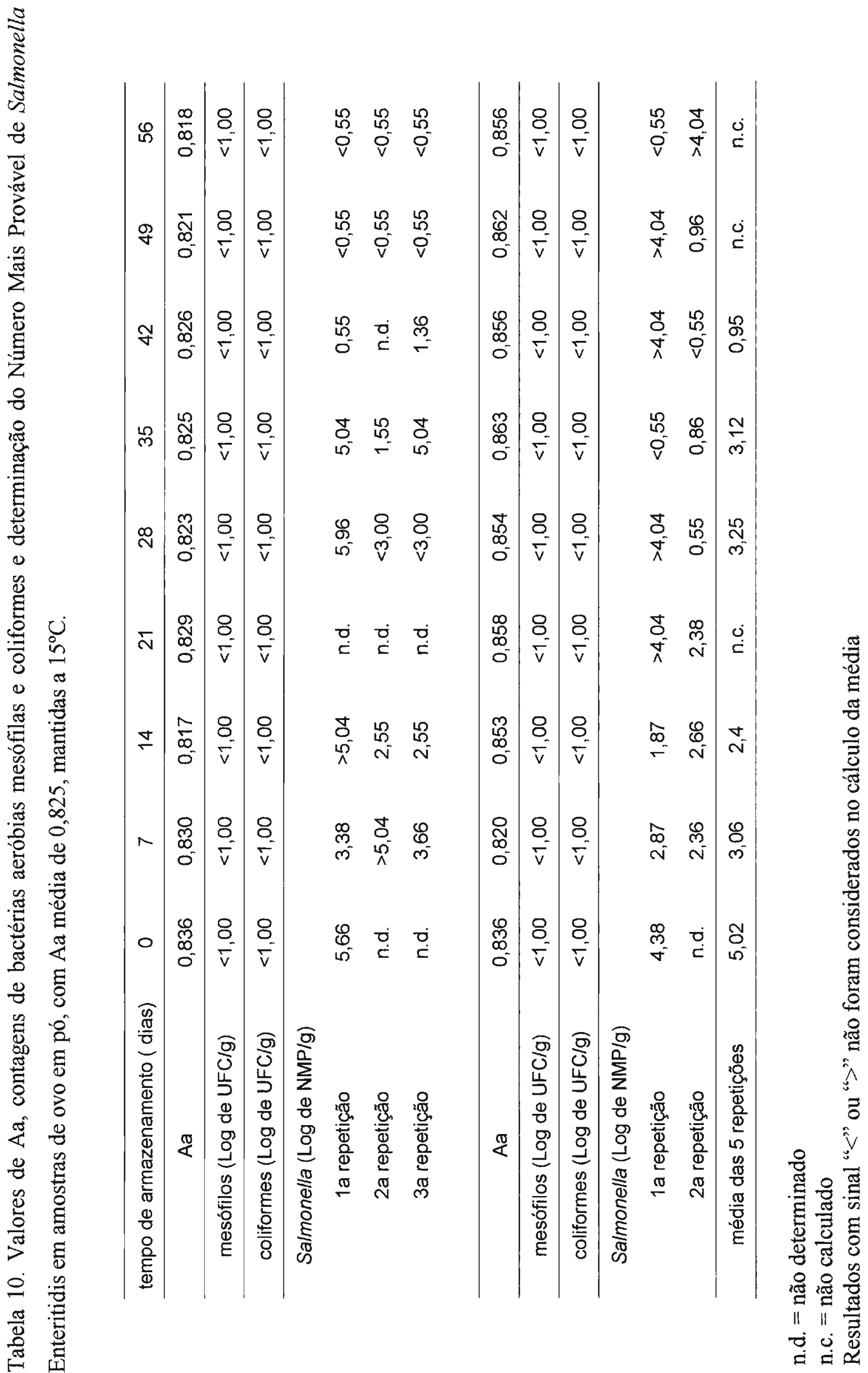




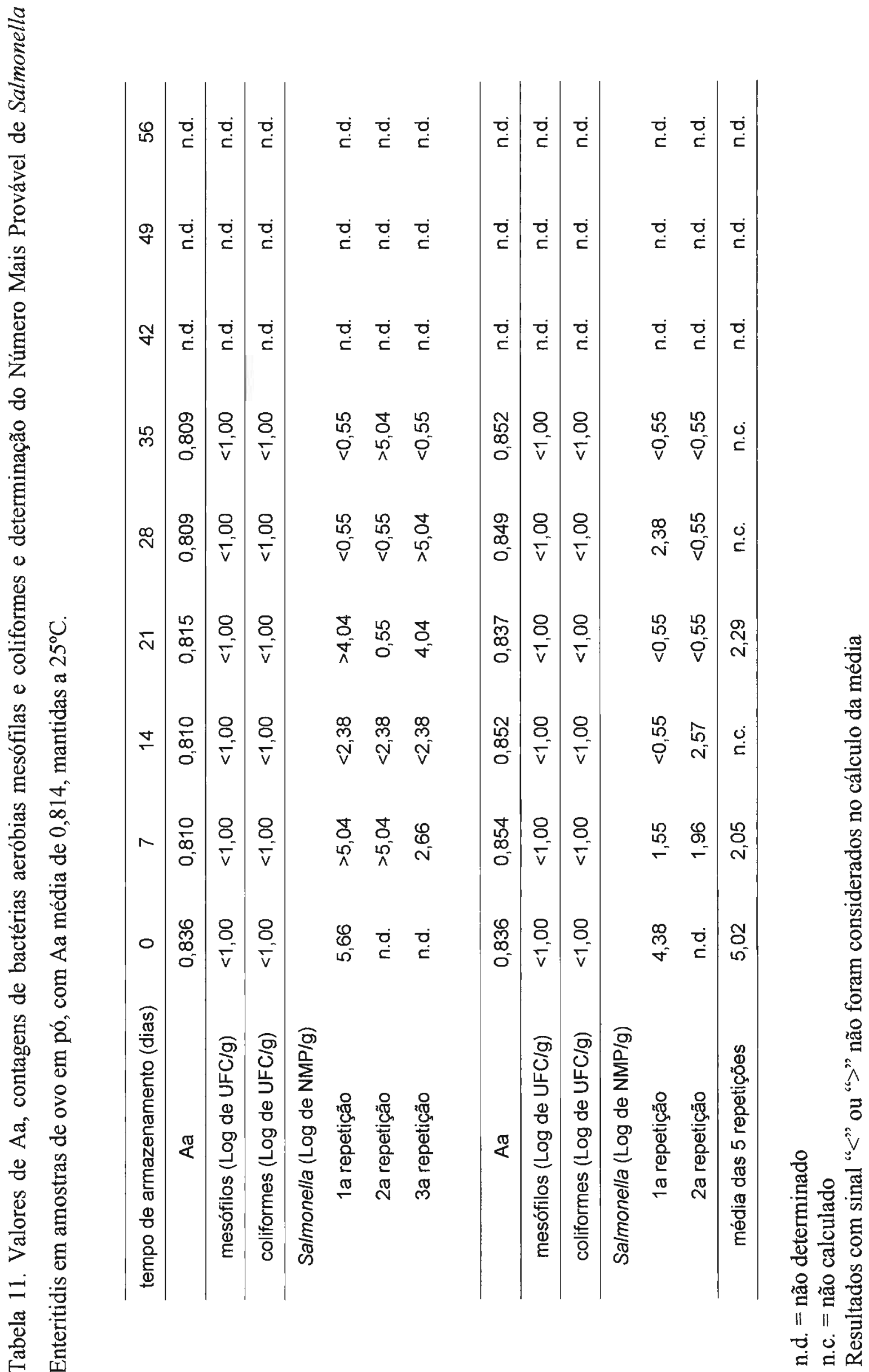




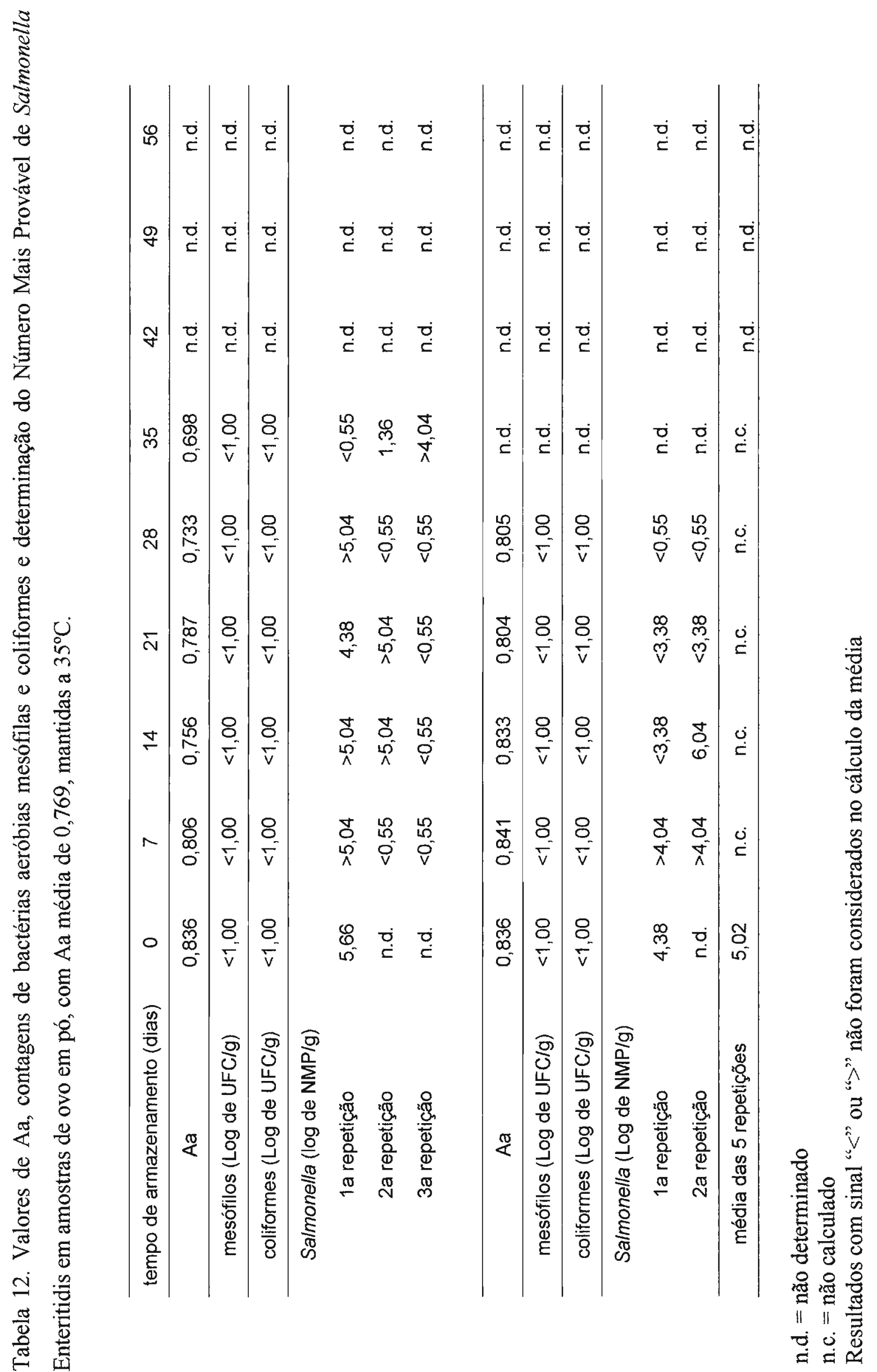




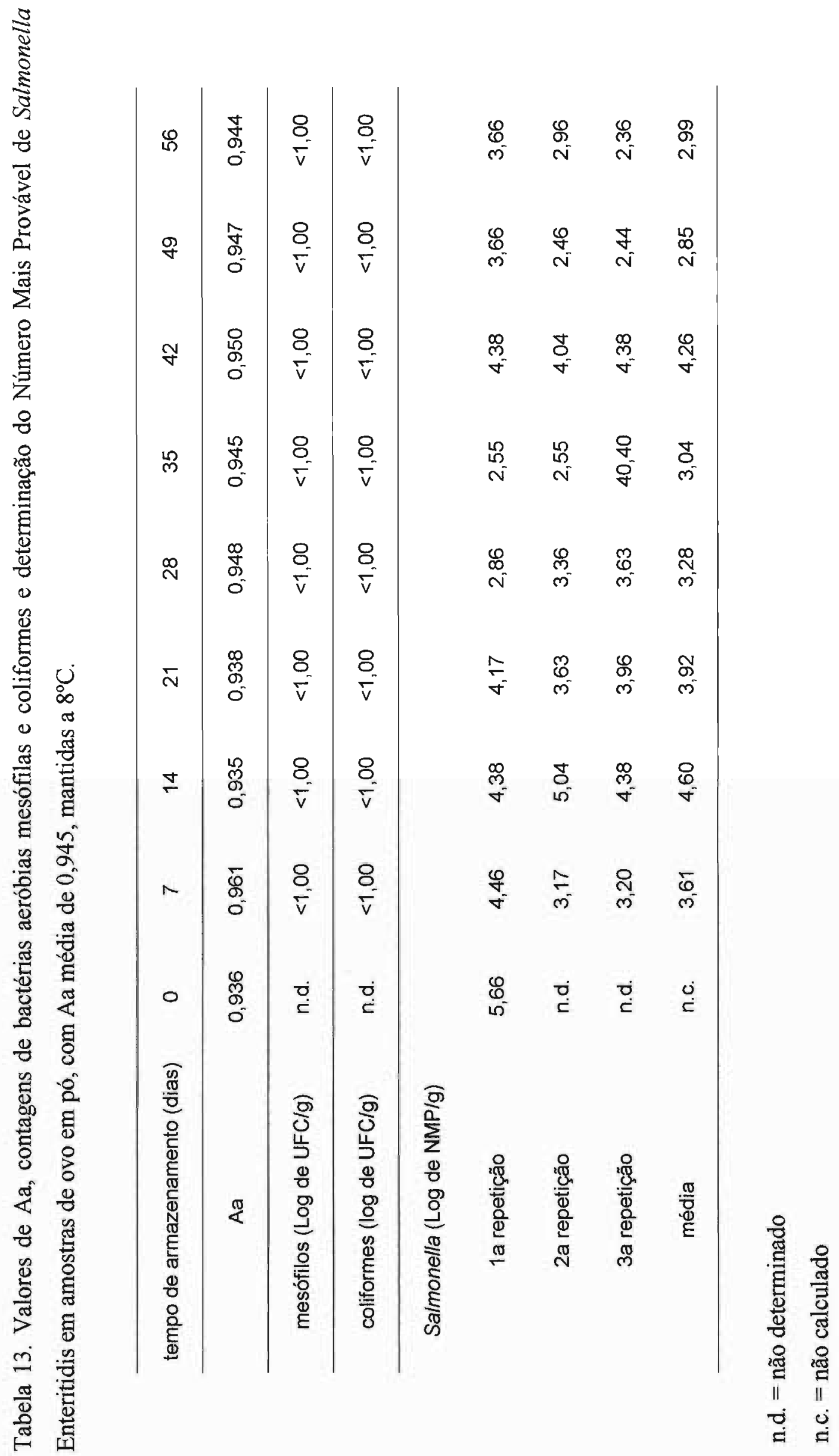




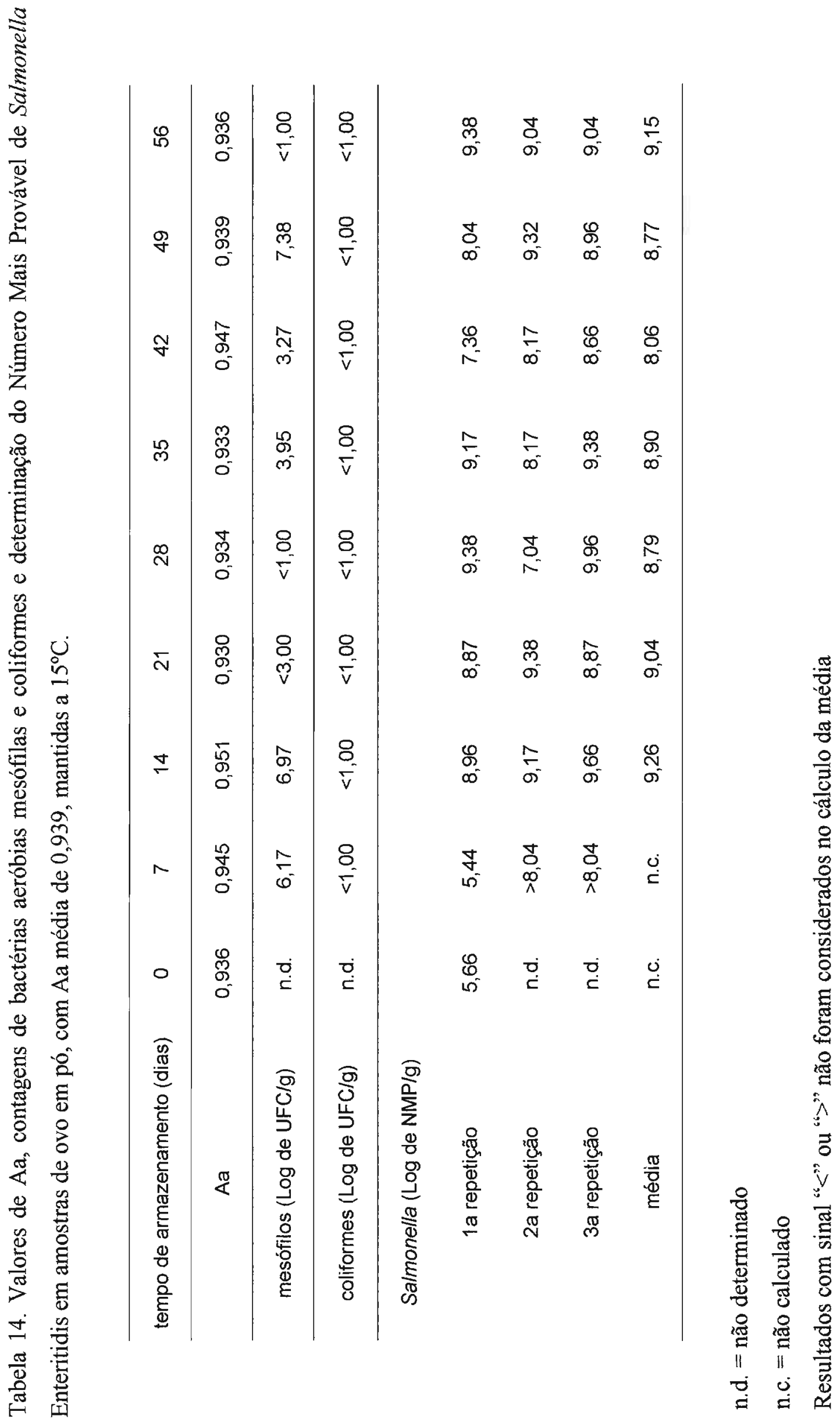




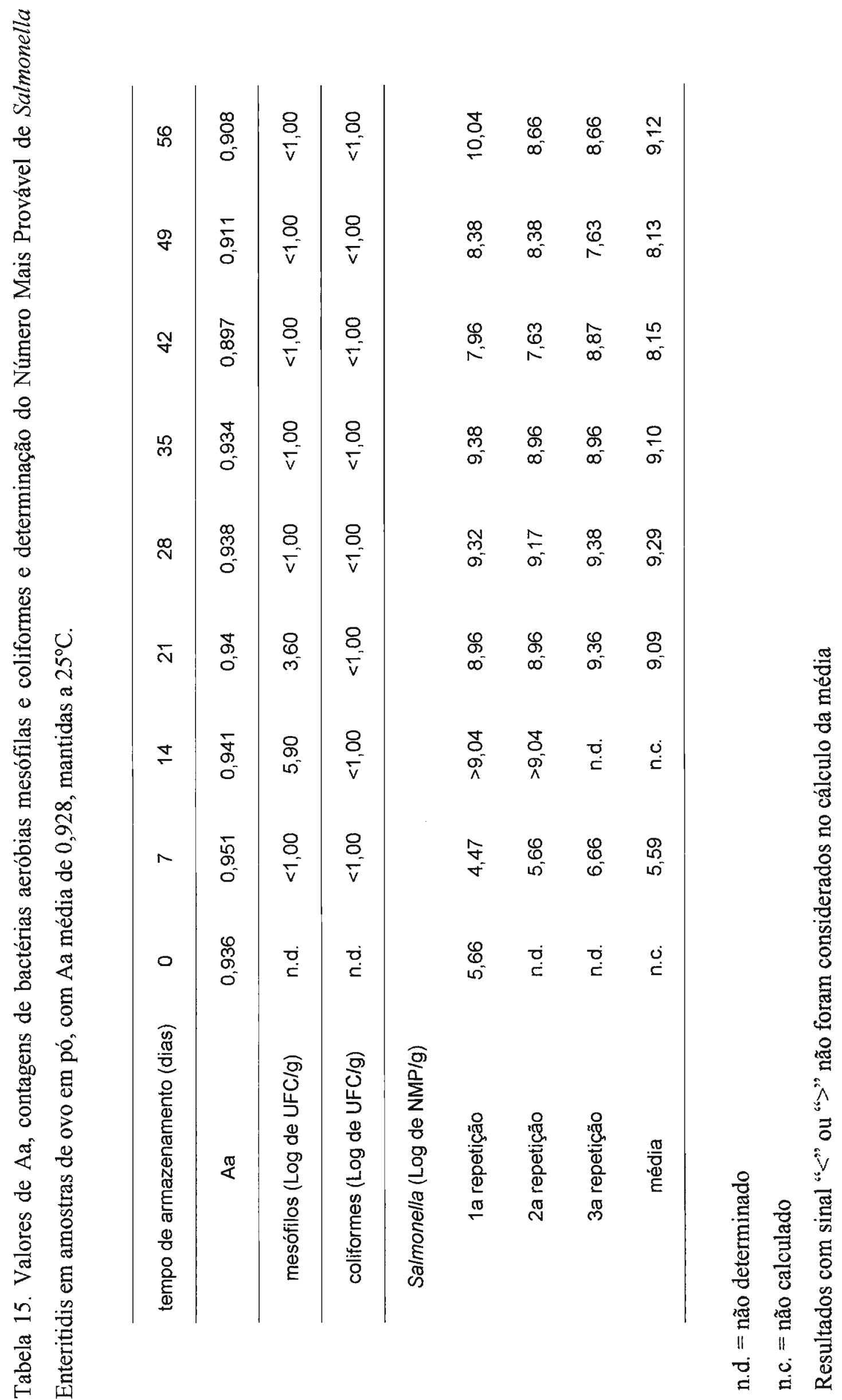




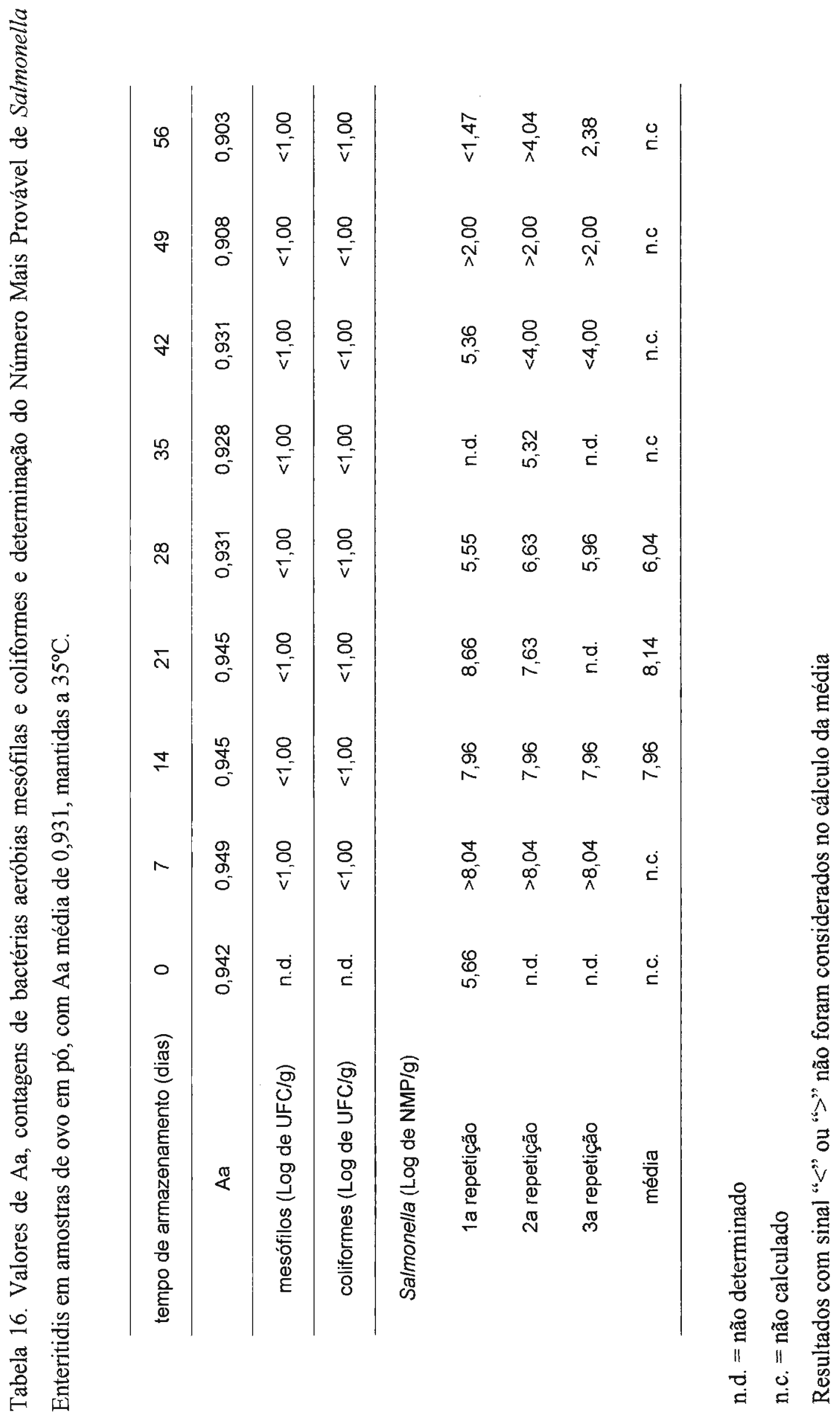




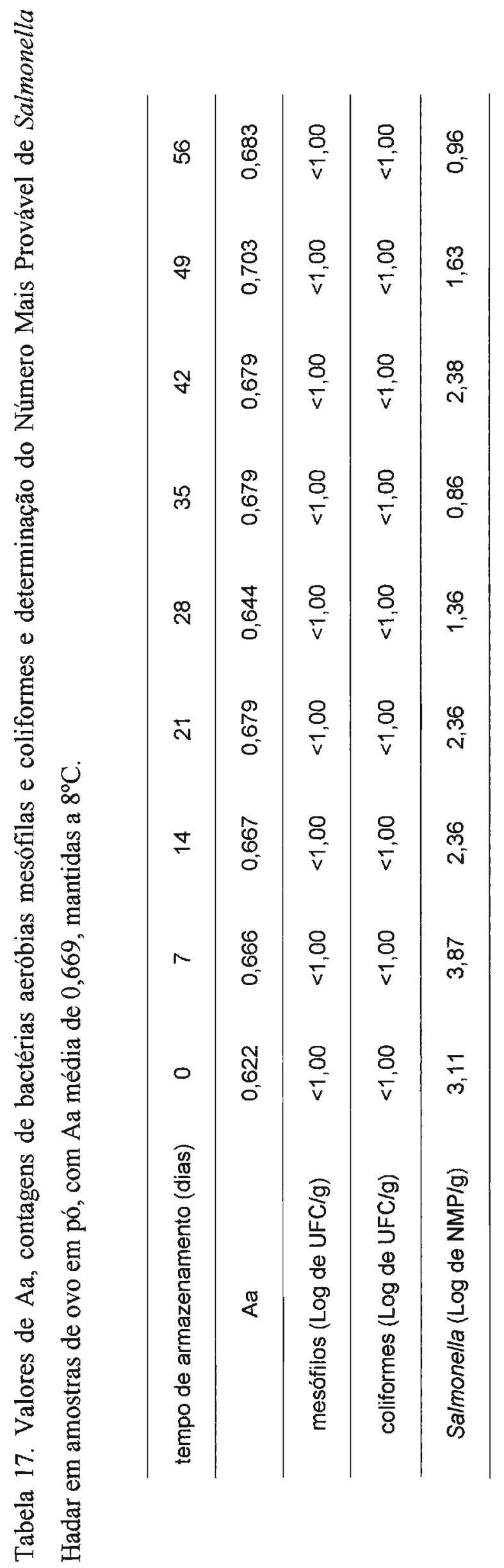




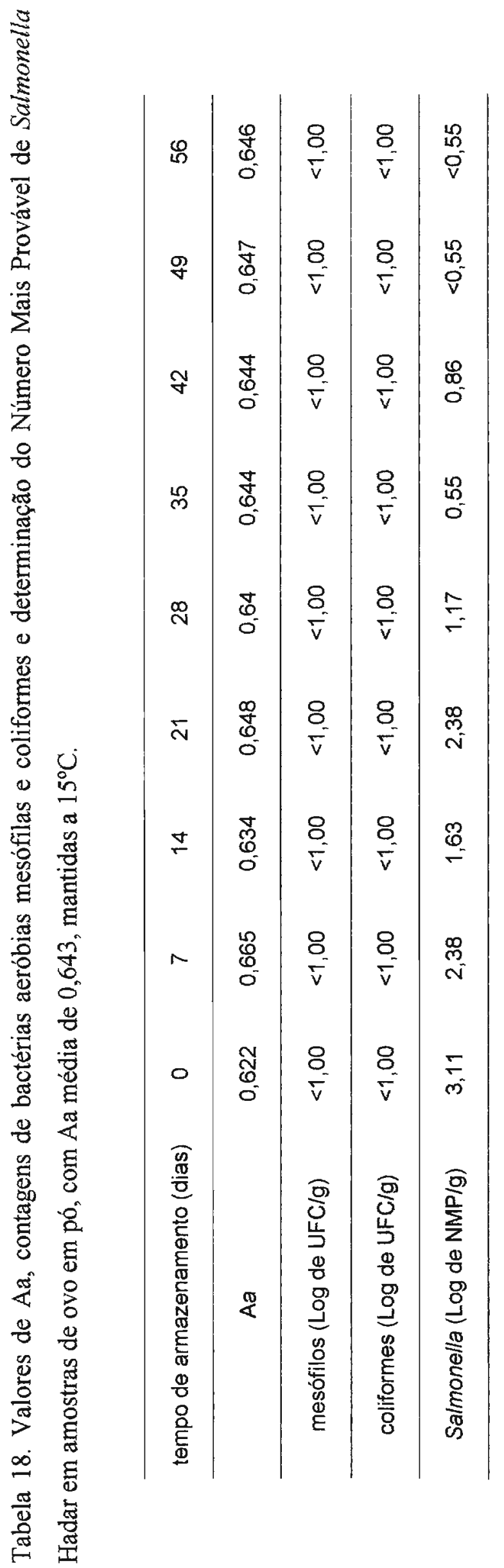




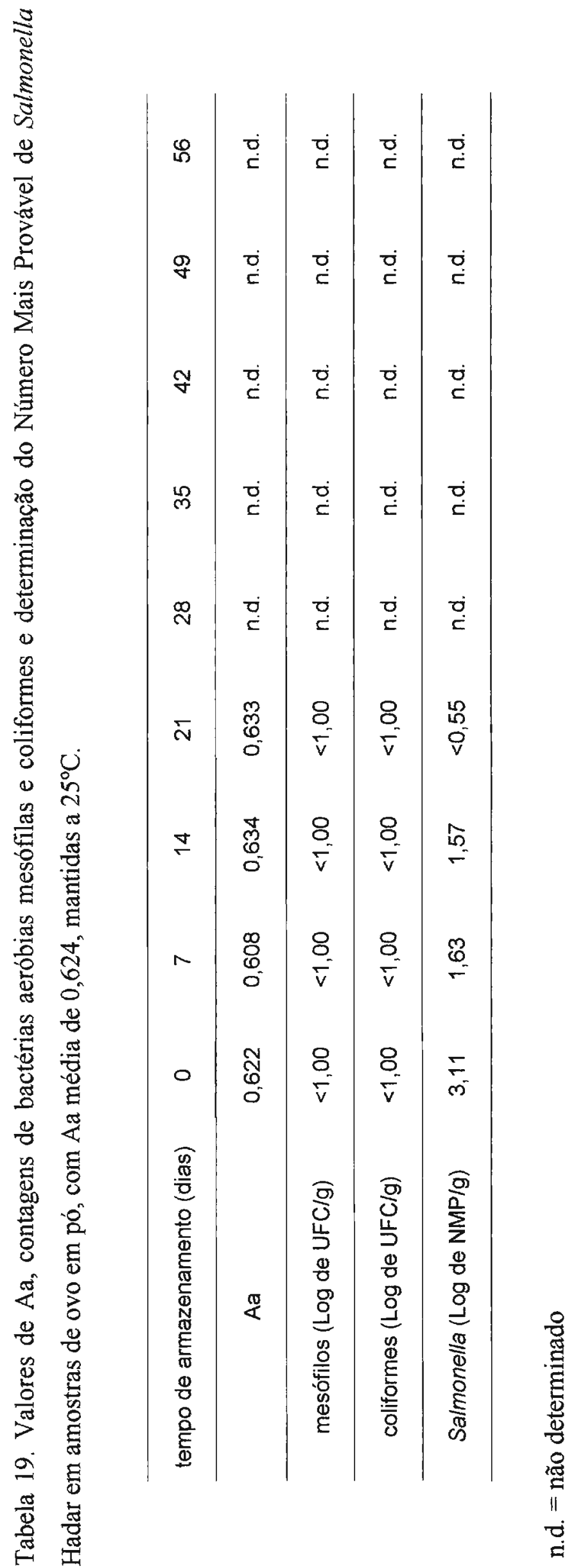




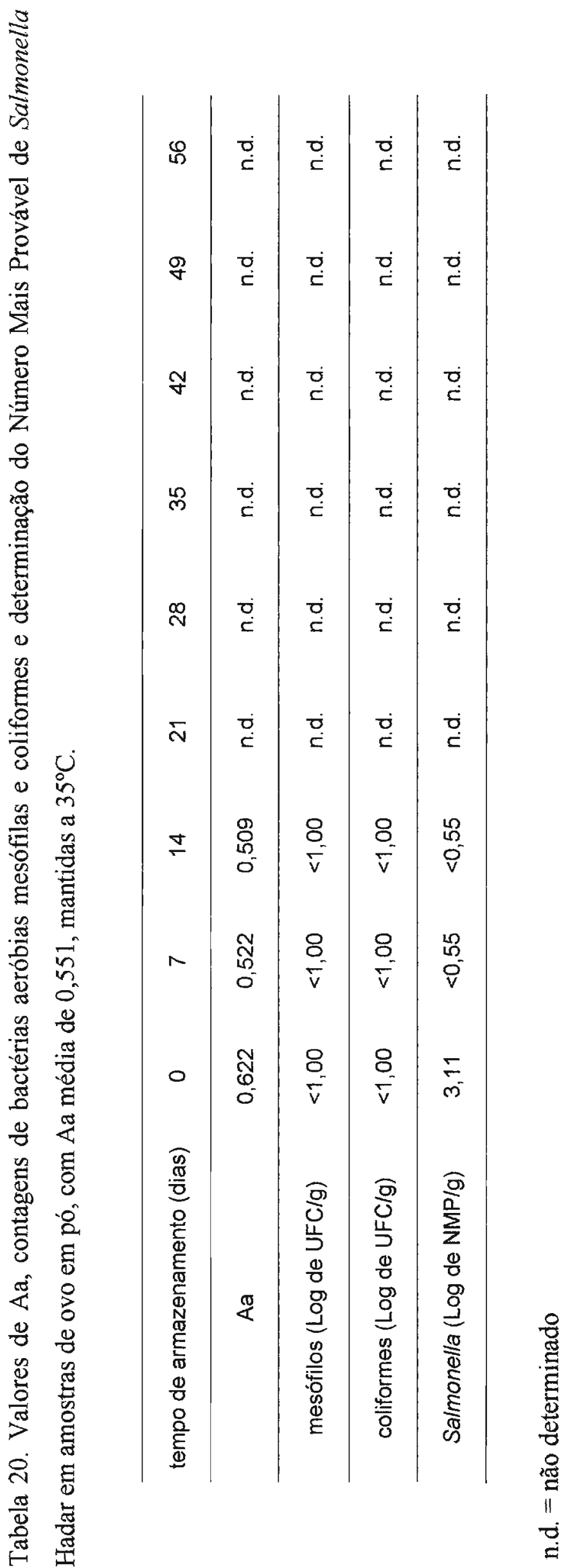


Tabela 21. Resultados do Teste de médias de Duncan aplicado às contagens de Salmonella Enteritidis nas amostras de ovo em pó com Aa de cerca de 0,4, durante armazenamento a $8^{\circ} \mathrm{C}, 15^{\circ} \mathrm{C}, 25^{\circ} \mathrm{C}$ e $35^{\circ} \mathrm{C}$ por até 56 dias.

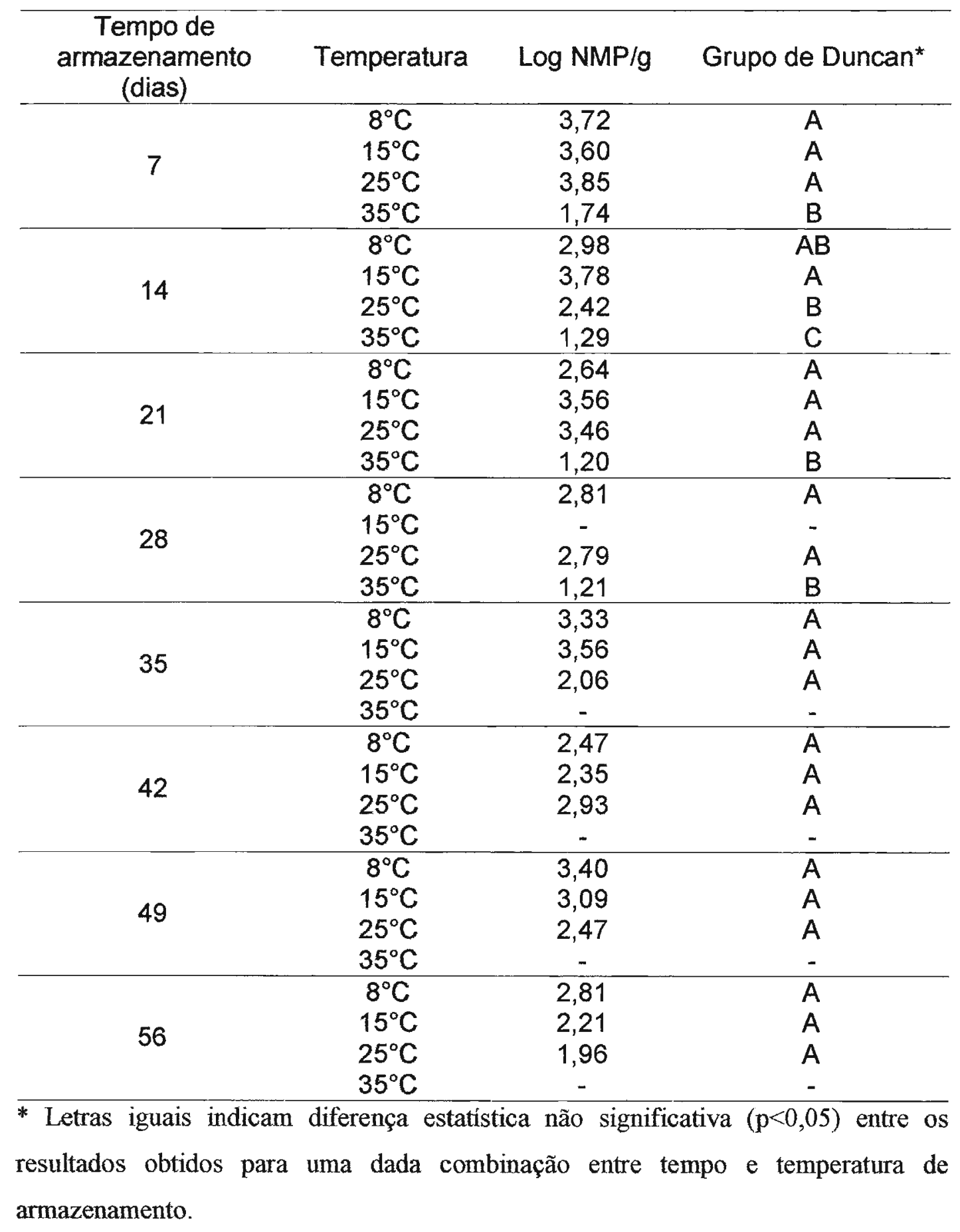


Tabela 22. Resultados do Teste de médias de Duncan aplicado às contagens de Salmonella Enteritidis nas amostras de ovo em pó com Aa de cerca de 0,6 , durante armazenamento a $8^{\circ} \mathrm{C}, 15^{\circ} \mathrm{C}, 25^{\circ} \mathrm{C}$ e $35^{\circ} \mathrm{C}$ por até 56 dias.

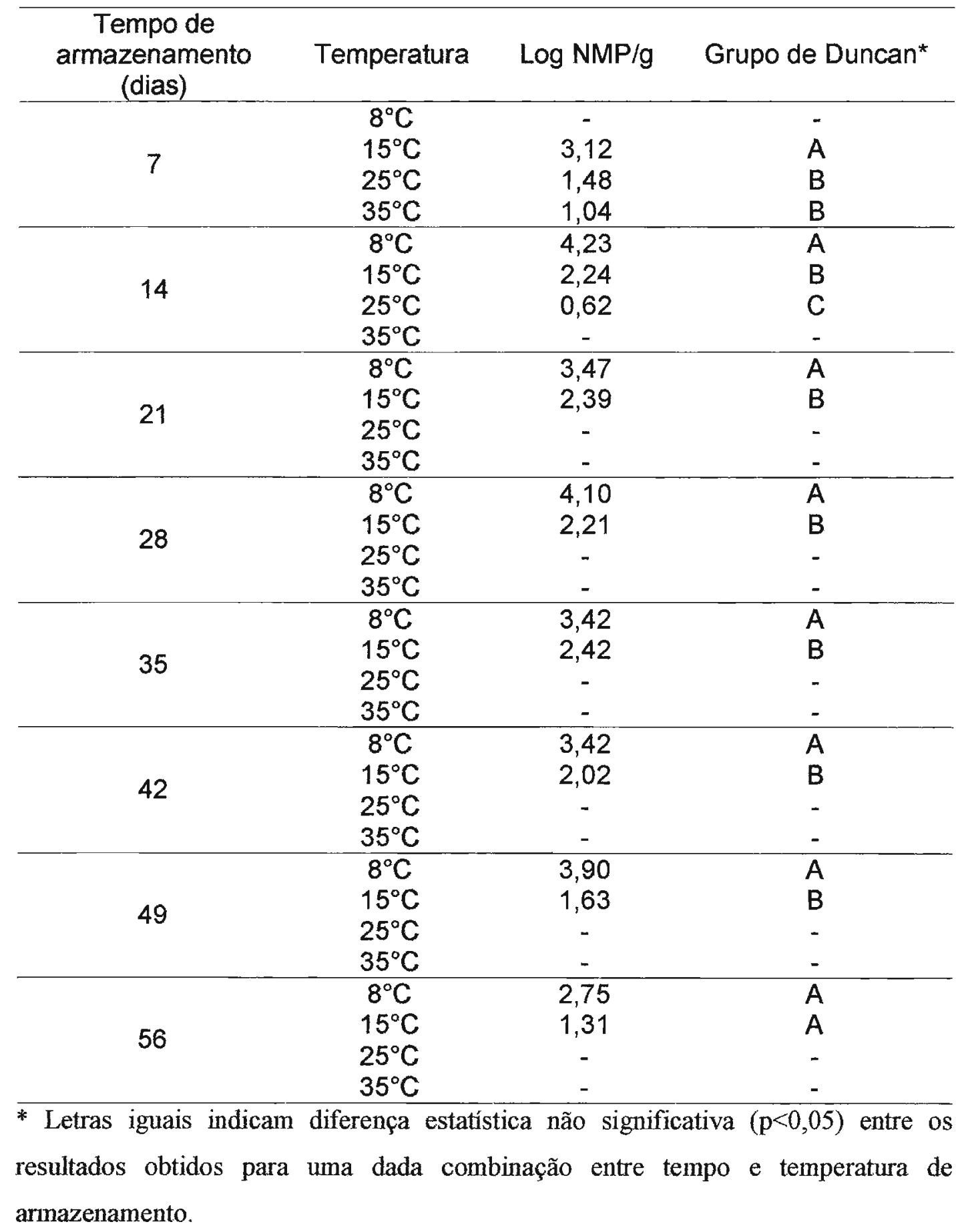


Tabela 23. Resultados do Teste de médias de Duncan aplicado às contagens de Salmonella Enteritidis nas amostras de ovo em pó com Aa de cerca de 0,8, durante armazenamento a $8^{\circ} \mathrm{C}, 15^{\circ} \mathrm{C}, 25^{\circ} \mathrm{C}$ e $35^{\circ} \mathrm{C}$ por até 56 dias.

\begin{tabular}{|c|c|c|c|}
\hline $\begin{array}{c}\text { Tempo de } \\
\text { armazenamento } \\
\text { (dias) }\end{array}$ & Temperatura & $\log N M P / g$ & Grupo de Duncan* \\
\hline \multirow{4}{*}{7} & $8^{\circ} \mathrm{C}$ & 3,25 & $\bar{A}$ \\
\hline & $15^{\circ} \mathrm{C}$ & 3,06 & A \\
\hline & $25^{\circ} \mathrm{C}$ & 2,05 & $A$ \\
\hline & $35^{\circ} \mathrm{C}$ & - & - \\
\hline \multirow{4}{*}{14} & $8^{\circ} \mathrm{C}$ & 3,60 & $A$ \\
\hline & $15^{\circ} \mathrm{C}$ & 2,40 & A \\
\hline & $25^{\circ} \mathrm{C}$ & - & - \\
\hline & $35^{\circ} \mathrm{C}$ & - & - \\
\hline \multirow{4}{*}{21} & $8^{\circ} \mathrm{C}$ & 2,80 & A \\
\hline & $15^{\circ} \mathrm{C}$ & - & - \\
\hline & $25^{\circ} \mathrm{C}$ & 2,29 & $A$ \\
\hline & $35^{\circ} \mathrm{C}$ & - & - \\
\hline \multirow{4}{*}{28} & $8^{\circ} \mathrm{C}$ & 3,06 & $A$ \\
\hline & $15^{\circ} \mathrm{C}$ & 3,25 & A \\
\hline & $25^{\circ} \mathrm{C}$ & - & - \\
\hline & $35^{\circ} \mathrm{C}$ & - & - \\
\hline \multirow{4}{*}{35} & $8^{\circ} \mathrm{C}$ & 2,29 & $A$ \\
\hline & $15^{\circ} \mathrm{C}$ & 3,12 & A \\
\hline & $25^{\circ} \mathrm{C}$ & - & - \\
\hline & $35^{\circ} \mathrm{C}$ & - & - \\
\hline \multirow{4}{*}{42} & $8^{\circ} \mathrm{C}$ & $2, \overline{47}$ & $A$ \\
\hline & $15^{\circ} \mathrm{C}$ & 0,95 & $\mathrm{~B}$ \\
\hline & $25^{\circ} \mathrm{C}$ & - & - \\
\hline & $35^{\circ} \mathrm{C}$ & - & - \\
\hline \multirow{4}{*}{49} & $8^{\circ} \mathrm{C}$ & 2,66 & - \\
\hline & $15^{\circ} \mathrm{C}$ & - & - \\
\hline & $25^{\circ} \mathrm{C}$ & - & - \\
\hline & $35^{\circ} \mathrm{C}$ & - & - \\
\hline \multirow{4}{*}{56} & $8^{\circ} \mathrm{C}$ & 2,54 & - \\
\hline & $15^{\circ} \mathrm{C}$ & - & - \\
\hline & $25^{\circ} \mathrm{C}$ & - & - \\
\hline & $35^{\circ} \mathrm{C}$ & - & - \\
\hline
\end{tabular}


Tabela 24. Resultado do Teste de médias de Duncan aplicado às contagens de Salmonella Enteritidis nas amostras de ovo em pó com Aa de cerca de 0,9 , durante armazenamento a $8^{\circ} \mathrm{C}$, $15^{\circ} \mathrm{C}, 25^{\circ} \mathrm{C}$ e $35^{\circ} \mathrm{C}$ por até 56 dias.

\begin{tabular}{|c|c|c|c|}
\hline $\begin{array}{l}\text { Tempo de } \\
\text { armazenamento } \\
\text { (dias) }\end{array}$ & Temperatura & $\log N M P / g$ & Grupo de Duncan* \\
\hline \multirow[t]{4}{*}{$-5+1$} & $8^{\circ} \mathrm{C}$ & 3,61 & B \\
\hline & $15^{\circ} \mathrm{C}$ & - & - \\
\hline & $25^{\circ} \mathrm{C}$ & 5,59 & $A$ \\
\hline & $35^{\circ} \mathrm{C}$ & - & - \\
\hline \multirow{4}{*}{14} & $8^{\circ} \mathrm{C}$ & 4,60 & C \\
\hline & $15^{\circ} \mathrm{C}$ & 9,26 & $A$ \\
\hline & $25^{\circ} \mathrm{C}$ & - & - \\
\hline & $35^{\circ} \mathrm{C}$ & 7,96 & $\mathrm{~B}$ \\
\hline \multirow{4}{*}{21} & $8^{\circ} \mathrm{C}$ & 3,92 & $\mathrm{C}$ \\
\hline & $15^{\circ} \mathrm{C}$ & 9,04 & A \\
\hline & $25^{\circ} \mathrm{C}$ & 9,09 & $A$ \\
\hline & $35^{\circ} \mathrm{C}$ & 8,14 & $\mathrm{~B}$ \\
\hline \multirow{4}{*}{28} & $8^{\circ} \mathrm{C}$ & 3,28 & $\mathrm{C}$ \\
\hline & $15^{\circ} \mathrm{C}$ & 8,79 & $A$ \\
\hline & $25^{\circ} \mathrm{C}$ & 9,29 & $A$ \\
\hline & $35^{\circ} \mathrm{C}$ & 6,04 & $\mathrm{~B}$ \\
\hline \multirow{4}{*}{35} & $8^{\circ} \mathrm{C}$ & 3,04 & $\mathrm{~B}$ \\
\hline & $15^{\circ} \mathrm{C}$ & 8,90 & $A$ \\
\hline & $25^{\circ} \mathrm{C}$ & 9,10 & $A$ \\
\hline & $35^{\circ} \mathrm{C}$ & - & - \\
\hline \multirow{4}{*}{42} & $8^{\circ} \mathrm{C}$ & 4,26 & $B$ \\
\hline & $15^{\circ} \mathrm{C}$ & 8,06 & A \\
\hline & $25^{\circ} \mathrm{C}$ & 8,15 & $A$ \\
\hline & $35^{\circ} \mathrm{C}$ & - & - \\
\hline \multirow{4}{*}{49} & $8^{\circ} \mathrm{C}$ & 2,85 & $\mathrm{~B}$ \\
\hline & $15^{\circ} \mathrm{C}$ & 8,77 & $A$ \\
\hline & $25^{\circ} \mathrm{C}$ & 8,13 & A \\
\hline & $35^{\circ} \mathrm{C}$ & - & - \\
\hline \multirow{4}{*}{56} & $8^{\circ} \mathrm{C}$ & 2,99 & B \\
\hline & $15^{\circ} \mathrm{C}$ & 9,15 & $A$ \\
\hline & $25^{\circ} \mathrm{C}$ & 9,12 & A \\
\hline & $35^{\circ} \mathrm{C}$ & - & - \\
\hline
\end{tabular}


Tabela 25. Resultados do Teste de médias de Duncan aplicado às contagens de Salmonella Enteritidis nas amostras de ovo em pó armazenado por 7 dias, nas temperaturas de $8^{\circ} \mathrm{C}, 15^{\circ} \mathrm{C}, 25^{\circ} \mathrm{C}$ e $35^{\circ} \mathrm{C}$.

\begin{tabular}{cccc}
\hline Temperatura & Aa & Log NMP/g & $\begin{array}{c}\text { Grupo de } \\
\text { Duncan* }\end{array}$ \\
\hline \multirow{3}{*}{$8^{\circ} \mathrm{C}$} & 0,4 & 3,72 & $\mathrm{~B}$ \\
& 0,6 & - & - \\
& 0,8 & 3,25 & $\mathrm{AB}$ \\
& 0,9 & 3,61 & $\mathrm{~A}$ \\
\hline \multirow{3}{*}{$15^{\circ} \mathrm{C}$} & 0,4 & 3,60 & $\mathrm{~A}$ \\
& 0,6 & 3,12 & $\mathrm{~A}$ \\
& 0,8 & 3,06 & $\mathrm{~A}$ \\
\multirow{3}{*}{$25^{\circ} \mathrm{C}$} & 0,9 & - & - \\
& 0,4 & 3,85 & $\mathrm{~B}$ \\
& 0,6 & 1,48 & $\mathrm{C}$ \\
& 0,8 & 2,05 & $\mathrm{~B}$ \\
$35^{\circ} \mathrm{C}$ & 0,9 & 5,59 & $\mathrm{~A}$ \\
& 0,4 & - & - \\
& 0,6 & - & - \\
\hline
\end{tabular}

* Letras iguais indicam diferença estatística não significativa $(\mathrm{p}<0,05)$ entre os resultados obtidos para uma dada combinação entre temperatura de armazenamento e a Aa do ovo. 
Tabela 26. Resultados do Teste de médias de Duncan aplicado às contagens de Salmonella Enteritidis nas amostras de ovo em pó armazenado por 14 dias, nas temperaturas de $8^{\circ} \mathrm{C}, 15^{\circ} \mathrm{C}, 25^{\circ} \mathrm{C}$ e $35^{\circ} \mathrm{C}$.

\begin{tabular}{cccc}
\hline Temperatura & Aa & Log NMP/g & $\begin{array}{c}\text { Grupo de } \\
\text { Duncan* }\end{array}$ \\
\hline \multirow{3}{*}{$8^{\circ} \mathrm{C}$} & 0,4 & 2,98 & $\mathrm{~B}$ \\
& 0,6 & 4,23 & $\mathrm{~A}$ \\
& 0,8 & 3,60 & $\mathrm{~A}$ \\
& 0,9 & 4,60 & $\mathrm{~A}$ \\
\hline \multirow{3}{*}{$15^{\circ} \mathrm{C}$} & 0,4 & 9,26 & $\mathrm{~A}$ \\
& 0,6 & 2,40 & $\mathrm{C}$ \\
& 0,8 & 2,24 & $\mathrm{C}$ \\
$25^{\circ} \mathrm{C}$ & 0,9 & 3,78 & $\mathrm{~B}$ \\
& 0,4 & 2,42 & $\mathrm{~A}$ \\
& 0,6 & 0,62 & $\mathrm{~B}$ \\
& 0,8 & - & - \\
$35^{\circ} \mathrm{C}$ & 0,9 & - & - \\
& 0,4 & 1,29 & $\mathrm{~B}$ \\
& 0,6 & - & - \\
\hline
\end{tabular}

* Letras iguais indicam diferença estatística não significativa $(p<0,05)$ entre os resultados obtidos para uma dada combinação entre temperatura de armazenamento e a Aa do ovo. 
Tabela 27. Resultados do Teste de médias de Duncan aplicado às contagens de Salmonella Enteritidis nas amostras de ovo em pó armazenado por 21 dias, nas temperaturas de $8^{\circ} \mathrm{C}, 15^{\circ} \mathrm{C}, 25^{\circ} \mathrm{C}$ e $35^{\circ} \mathrm{C}$.

\begin{tabular}{cccc}
\hline \multirow{3}{*}{ Temperatura } & $\mathrm{Aa}$ & Log NMP/g & $\begin{array}{c}\text { Grupo de } \\
\text { Duncan }\end{array}$ \\
\hline \multirow{3}{*}{$8^{\circ} \mathrm{C}$} & 0,4 & 2,64 & $\mathrm{~A}$ \\
& 0,6 & 3,47 & $\mathrm{~A}$ \\
& 0,8 & 2,80 & $\mathrm{~A}$ \\
& 0,9 & 3,92 & $\mathrm{~A}$ \\
\hline \multirow{3}{*}{$15^{\circ} \mathrm{C}$} & 0,4 & 3,56 & $\mathrm{~B}$ \\
& 0,6 & 2,39 & $\mathrm{C}$ \\
& 0,8 & - & - \\
& 0,9 & 9,04 & $\mathrm{~A}$ \\
$25^{\circ} \mathrm{C}$ & 0,4 & 2,42 & $\mathrm{~B}$ \\
& 0,6 & 0,62 & $\mathrm{C}$ \\
& 0,8 & 2,29 & $\mathrm{~B}$ \\
& 0,9 & 9,09 & $\mathrm{~A}$ \\
\hline \multirow{3}{*}{$35^{\circ} \mathrm{C}$} & 0,4 & 1,20 & $\mathrm{~B}$ \\
& 0,6 & - & - \\
& 0,8 & - & - \\
\hline
\end{tabular}

* Letras iguais indicam diferença estatística não significativa $(p<0,05)$ entre os resultados obtidos para uma dada combinação entre temperatura de armazenamento a Aa do ovo. 
Tabela 28. Resultados do Teste de médias de Duncan aplicado às contagens de Salmonella Enteritidis nas amostras de ovo em pó armazenado por 28 dias, nas temperaturas de $8^{\circ} \mathrm{C}, 15^{\circ} \mathrm{C}, 25^{\circ} \mathrm{C}$ e $35^{\circ} \mathrm{C}$.

\begin{tabular}{cccc}
\hline Temperatura & Aa & Log NMP/g & $\begin{array}{c}\text { Grupo de } \\
\text { Duncan* }\end{array}$ \\
\hline \multirow{3}{*}{$8^{\circ} \mathrm{C}$} & 0,4 & 2,81 & $\mathrm{~B}$ \\
& 0,6 & 4,10 & $\mathrm{~A}$ \\
& 0,8 & 3,06 & $\mathrm{AB}$ \\
& 0,9 & 3,28 & $\mathrm{~B}$ \\
\hline \multirow{3}{*}{$15^{\circ} \mathrm{C}$} & 0,4 & 3,56 & $\mathrm{~B}$ \\
& 0,6 & 2,21 & $\mathrm{~B}$ \\
& 0,8 & 3,25 & $\mathrm{~B}$ \\
\multirow{3}{*}{$25^{\circ} \mathrm{C}$} & 0,9 & 8,79 & $\mathrm{~A}$ \\
& 0,4 & 3,46 & $\mathrm{~B}$ \\
& 0,6 & - & - \\
& 0,8 & - & - \\
$35^{\circ} \mathrm{C}$ & 0,9 & 9,29 & $\mathrm{~A}$ \\
& 0,4 & 1,21 & $\mathrm{~B}$ \\
& 0,6 & - & - \\
& 0,8 & - & $\mathrm{A}$ \\
\hline
\end{tabular}

* Letras iguais indicam diferença estatística não significativa $(p<0,05)$ entre os resultados obtidos para uma dada combinação entre temperatura de armazenamento a Aa do ovo. 
Tabela 29. Resultados do Teste de médias de Duncan aplicado às contagens de Salmonella Enteritidis nas amostras de ovo em pó armazenado por 35 dias, nas temperaturas de $8^{\circ} \mathrm{C}, 15^{\circ} \mathrm{C}, 25^{\circ} \mathrm{C}$ e $35^{\circ} \mathrm{C}$.

\begin{tabular}{cccc}
\hline Temperatura & Aa & Log NMP/g & $\begin{array}{c}\text { Grupo de } \\
\text { Duncan }\end{array}$ \\
\hline \multirow{3}{*}{$8^{\circ} \mathrm{C}$} & 0,4 & 3,33 & $\mathrm{~A}$ \\
& 0,6 & 3,42 & $\mathrm{~A}$ \\
& 0,8 & 2,29 & $\mathrm{~A}$ \\
& 0,9 & 3,04 & $\mathrm{~A}$ \\
\hline \multirow{3}{*}{$15^{\circ} \mathrm{C}$} & 0,4 & 3,56 & $\mathrm{~B}$ \\
& 0,6 & 2,42 & $\mathrm{~B}$ \\
& 0,8 & 3,12 & $\mathrm{~B}$ \\
$25^{\circ} \mathrm{C}$ & 0,9 & 8,90 & $\mathrm{~A}$ \\
& 0,4 & 2,06 & $\mathrm{~B}$ \\
& 0,6 & - & - \\
& 0,8 & - & - \\
$35^{\circ} \mathrm{C}$ & 0,9 & 9,10 & $\mathrm{~A}$ \\
& 0,4 & - & - \\
& 0,6 & - & - \\
& 0,8 & - & -
\end{tabular}

* Letras iguais indicam diferença estatística não significativa $(p<0,05)$ entre os resultados obtidos para uma dada combinação entre temperatura de armazenamento a Aa do ovo. 
Tabela 30. Resultados do Teste de médias de Duncan aplicado às contagens de Salmonella Enteritidis nas amostras de ovo em pó armazenado por 42 dias, nas temperaturas de $8^{\circ} \mathrm{C}, 15^{\circ} \mathrm{C}, 25^{\circ} \mathrm{C}$ e $35^{\circ} \mathrm{C}$.

\begin{tabular}{cccc}
\hline \multirow{3}{*}{ Temperatura } & Aa & Log NMP/g & $\begin{array}{c}\text { Grupo de } \\
\text { Duncan* }\end{array}$ \\
\hline \multirow{3}{*}{$8^{\circ} \mathrm{C}$} & 0,4 & 2,47 & $\mathrm{C}$ \\
& 0,6 & 3,42 & $\mathrm{~B}$ \\
& 0,8 & 2,47 & $\mathrm{C}$ \\
& 0,9 & 4,26 & $\mathrm{~A}$ \\
\hline \multirow{3}{*}{$15^{\circ} \mathrm{C}$} & 0,4 & 2,35 & $\mathrm{~B}$ \\
& 0,6 & 2,02 & $\mathrm{BC}$ \\
& 0,8 & 0,95 & $\mathrm{C}$ \\
\multirow{3}{*}{$25^{\circ} \mathrm{C}$} & 0,9 & 8,06 & $\mathrm{~A}$ \\
& 0,4 & 2,93 & $\mathrm{~B}$ \\
& 0,6 & - & - \\
& 0,8 & - & - \\
& 0,9 & 8,15 & $\mathrm{~A}$ \\
\hline $35^{\circ} \mathrm{C}$ & 0,4 & - & - \\
& 0,6 & - & - \\
& 0,8 & - & -
\end{tabular}

* Letras iguais indicam diferença estatística não significativa $(p<0,05)$ entre os resultados obtidos para uma dada combinação entre temperatura de armazenamento a Aa do ovo. 
Tabela 31. Resultados do Teste de médias de Duncan aplicado às contagens de Salmonella Enteritidis nas amostras de ovo em pó armazenado por 49 dias, nas temperaturas de $8^{\circ} \mathrm{C}, 15^{\circ} \mathrm{C}, 25^{\circ} \mathrm{C}$ e $35^{\circ} \mathrm{C}$.

\begin{tabular}{cccc}
\hline \multirow{3}{*}{ Temperatura } & Aa & Log NMP/g & $\begin{array}{c}\text { Grupo de } \\
\text { Duncan }\end{array}$ \\
\hline \multirow{3}{*}{$8^{\circ} \mathrm{C}$} & 0,4 & 3,40 & $\mathrm{~A}$ \\
& 0,6 & 3,90 & $\mathrm{~A}$ \\
& 0,8 & 2,66 & $\mathrm{~A}$ \\
& 0,9 & 2,85 & $\mathrm{~A}$ \\
$15^{\circ} \mathrm{C}$ & 0,4 & 3,09 & $\mathrm{~B}$ \\
& 0,6 & 1,63 & $\mathrm{C}$ \\
& 0,8 & - & - \\
$25^{\circ} \mathrm{C}$ & 0,9 & 8,77 & $\mathrm{~A}$ \\
& 0,4 & 2,47 & $\mathrm{~B}$ \\
& 0,6 & - & - \\
& 0,8 & - & - \\
$35^{\circ} \mathrm{C}$ & 0,9 & 8,13 & $\mathrm{~A}$ \\
& 0,4 & - & - \\
& 0,6 & - & - \\
\hline
\end{tabular}

* Letras iguais indicam diferença estatística não significativa $(\mathrm{p}<0,05)$ entre os resultados obtidos para uma dada combinação entre temperatura de armazenamento a Aa do ovo. 
Tabela 32. Resultados do Teste de médias de Duncan aplicado às contagens de Salmonella Enteritidis nas amostras de ovo em pó armazenado por 56 dias, nas temperaturas de $8^{\circ} \mathrm{C}, 15^{\circ} \mathrm{C}, 25^{\circ} \mathrm{C}$ e $35^{\circ} \mathrm{C}$.

\begin{tabular}{cccc}
\hline \multirow{3}{*}{ Temperatura } & Aa & Log NMP/g & $\begin{array}{c}\text { Grupo de } \\
\text { Duncan* }\end{array}$ \\
\hline \multirow{3}{*}{$8^{\circ} \mathrm{C}$} & 0,4 & 2,81 & $\mathrm{~A}$ \\
& 0,6 & 2,75 & $\mathrm{~A}$ \\
& 0,8 & 2,54 & $\mathrm{~A}$ \\
& 0,9 & 2,99 & $\mathrm{~A}$ \\
\hline \multirow{3}{*}{$15^{\circ} \mathrm{C}$} & 0,4 & 2,21 & $\mathrm{~B}$ \\
& 0,6 & 1,31 & $\mathrm{C}$ \\
& 0,8 & - & - \\
& 0,9 & 9,15 & $\mathrm{~A}$ \\
\hline \multirow{3}{*}{$25^{\circ} \mathrm{C}$} & 0,4 & 1,96 & $\mathrm{~B}$ \\
& 0,6 & - & - \\
& 0,8 & - & - \\
& 0,9 & 9,12 & $\mathrm{~A}$ \\
\hline \multirow{3}{*}{$35^{\circ} \mathrm{C}$} & 0,4 & - & - \\
& 0,6 & - & - \\
& 0,8 & - & - \\
\hline
\end{tabular}

* Letras iguais indicam diferença estatística não significativa $(\mathrm{p}<0,05)$ entre os resultados obtidos para uma dada combinação entre temperatura de armazenamento a Aa do ovo. 


\section{Discussão}

A análise de variância ANOVA aplicada aos resultados indicou que as variáveis Aa e temperatura de armazenamento são dependentes $(p<0,05)$. Assim, admitindo-se que as amostras de ovo em pó continham no momento da inoculação cerca de $10^{4} \mathrm{UFC} / \mathrm{g}$ de Salmonella, nas amostras com Aa de cerca de 0,4 , mantidas na temperatura de $8^{\circ} \mathrm{C}$, houve um decréscimo médio de 1,2 ciclos log na contagem de Salmonella, após 56 dias de armazenamento (Tabela 1). Já na temperatura de armazenamento de $15^{\circ} \mathrm{C}$ (Tabela 2), este decréscimo, após os mesmos 56 dias de armazenamento, foi de 1,8 ciclos $\log$. Na temperatura de $25^{\circ} \mathrm{C}$ (Tabela 3), este decréscimo foi um pouco maior, de 2 ciclos log. Para a temperatura de $35^{\circ} \mathrm{C}$ (Tabela 4 ), houve uma redução de 2,2 ciclos log já após 7 dias de estocagem. Nessa temperatura e com 35 dias de armazenamento, Salmonella já não pode mais ser detectada nas amostras pelo método empregado.

Nas amostras com Aa de cerca de 0,6 mantidas na temperatura de $8^{\circ} \mathrm{C}$ (Tabela 5), o comportamento de Salmonella foi semelhante ao observado nas amostras com Aa de cerca de 0,4, ou seja, a redução na contagem também foi de 1,2 ciclos log após 56 dias de armazenamento, considerando-se que a contaminação inicial era de $10^{4} \mathrm{UFC} / \mathrm{g}$. Já para as outras temperaturas de armazenamento, a redução da contagem de Salmonella foi maior. Para o armazenamento a $15^{\circ} \mathrm{C}$ (Tabela 6), a redução média após 56 dias de armazenamento foi de 2,7 ciclos log. Já na temperatura de $25^{\circ} \mathrm{C}$ (Tabela 7), o microrganismo não sobreviveu aos 56 dias de armazenamento. Não foi mais possível detectar Salmonella após 21 dias de armazenamento nesta temperatura. E na temperatura de armazenamento de $35^{\circ} \mathrm{C}$ (Tabela 8), Salmonella não pode mais ser isolada do ovo com 14 dias de armazenamento pelo método empregado.

No ovo com Aa de cerca de 0,8 armazenado a $8^{\circ} \mathrm{C}$ (Tabela 9), observou-se um decréscimo de 2,6 ciclos log na contagem de Salmonella após 56 dias de armazenamento, admitindo-se que a contaminação inicial era de $10^{5} \mathrm{UFC} / \mathrm{g}$. No produto armazenado a $15^{\circ} \mathrm{C}$ (Tabela 10), houve uma redução de 2,1 ciclos $\log \operatorname{logo}$ aos 7 dias de armazenamento. Com 49 dias de estocagem, Salmonella não pode mais ser enumerada. $\mathrm{Na}$ temperatura de $25^{\circ} \mathrm{C}$ (Tabela 11), após 7 dias de armazenamento, o decréscimo na contagem foi de 3,1 ciclos log e com 28 dias de armazenamento não foi possivel enumerar Salmonella. Na temperatura de armazenamento de $35^{\circ} \mathrm{C}$ (Tabela 12), já com 7 dias de armazenamento, não foi possivel se detectar presença de Salmonella pelo método empregado. 
Nas amostras com Aa de cerca de 0,9 , o comportamento de Salmonella nas amostras armazenadas nas diferentes temperaturas foi diferente daquele observado nas amostras com $\mathrm{Aa}$ mais baixa. Nas amostras mantidas nas temperaturas de $15^{\circ} \mathrm{C}$ (Tabela 14) e $25^{\circ} \mathrm{C}$ (Tabela 15), observou-se intensa multiplicação de Salmonella, enquanto naquelas mantidas na temperatura de $8^{\circ} \mathrm{C}$ (Tabela 13), houve redução nas contagens. Considerando-se a contaminação inicial de $10^{5}$ $\mathrm{UFC} / \mathrm{g}$, observou-se que a $8^{\circ} \mathrm{C}$ ocorreu uma redução inicial de 2 ciclos $\log$ após 7 dias de armazenamento, que aumentou para 2,7 ciclos log após os 56 dias de armazenamento. Já nas temperaturas de $15^{\circ} \mathrm{C} \mathrm{e} 25^{\circ} \mathrm{C}$, após os 56 dias de armazenamento a concentração de Salmonella já era da ordem de $10^{9} \mathrm{NMP} / \mathrm{g}$. Essa concentração já havia sido obtida após 14 dias nas temperaturas de $15^{\circ} \mathrm{C}$ e $25^{\circ} \mathrm{C}$. Na temperatura de $35^{\circ} \mathrm{C}$ (Tabela 16), houve inicialmente um aumento na população, que em 7 dias já estava superior a $10^{8} \mathrm{NMP} / \mathrm{g}$, mas após este período, houve um gradativo decréscimo na população.

Analisando-se a influência da temperatura no comportamento de Salmonella no ovo em pó com as Aa estudadas, pode-se notar que a $8^{\circ} \mathrm{C}$ a cinética de multiplicação de Salmonella nas amostras com Aa de cerca de 0,4 e 06 foi semelhante (Tabelas 1 e 5). Também os comportamentos nas amostras com Aa de cerca de 0,8 e 0,9 foi semelhante, nesta temperatura (Tabelas 9 e 13).

Nas amostras mantidas na temperatura de $15^{\circ} \mathrm{C}$, a diminuição na contagem de Salmonella foi mais pronunciada do que a ocorrida nas amostras a $8^{\circ} \mathrm{C}$. Após 56 dias de armazenagem nesta temperatura, houve nas Aa de cerca de 0,4 (Tabela 2) e cerca de 0,6 (Tabela 6) uma diminuição de 1,79 e 2,7 ciclos log respectivamente. Para a Aa de cerca de 0,8 (Tabela 10) Salmonella não pode ser recuperada com 49 dias de armazenamento. Já para Aa de cerca de 0,9 (Tabela 14) houve um acréscimo de 3,5 ciclos log após os 56 dias de armazenamento.

$\mathrm{Na}$ temperatura de $25^{\circ} \mathrm{C}$ em Aa de cerca de 0,4 (Tabela 3) houve um decréscimo de 2 ciclos log na contagem de Salmonella após os 56 dias de armazenagem, já nas Aa de cerca de 0,6 (Tabela 7) e cerca de 0,8 (Tabela 11) houve inativação total, respectivamente com 21 e 28 dias de armazenagem. Na Aa de cerca de 0,9 (Tabela 15) houve um aumento de 3,5 ciclos log na população de Salmonella.

$\mathrm{Na}$ temperatura de $35^{\circ} \mathrm{C}$ em Aa de cerca de 0,4 (Tabela 4), cerca de 0,6 (Tabela 8) e cerca de 0,8 (Tabela 12), não foi possível se enumerar Salmonella após 35, 14 e 7 dias de armazenagem respectivamente. Em Aa de cerca de 0,9 (Tabela 16), houve um aumento de 2,3 ciclos log após 
14 dias de armazenamento e após este período, houve decréscimo na contagem da população de Salmonella.

Os resultados indicam que em Aa abaixo do mínimo necessário para a multiplicação de Salmonella, ou seja, 0,93 (Franco \& Landgraf, 1996; Jay, 2000), a baixa temperatura protege o microrganismo em questão e quanto mais baixa a Aa, maior é esta proteção. Este resultado está de acordo com aqueles relatados por Juven et al.(1984), que estudaram a sobrevivência $S$. Montevideo e $S$. Heidelberg em leite em pó, chocolate em pó, alimento para aves e farinha de carne e ossos. Esses autores verificaram também que a sobrevivência do microrganismo aumentava com a diminuição da Aa.

Radkowski (2002), que inoculou separadamente 3 cepas de Salmonella em ovo em pó (S. Enteritidis, $S$. Typhimurium e $S$. Agona) e armazenou estas amostras a $20^{\circ} \mathrm{C}, 30^{\circ} \mathrm{C}, 40^{\circ} \mathrm{C}, 45^{\circ} \mathrm{C} \mathrm{e}$ $50^{\circ} \mathrm{C}$ por $0,1,2,3,7$ e 14 dias, observou que quanto mais alta a temperatura menor foi o tempo de sobrevivência do microrganismo. $S$. Typhimurium foi a primeira a ser inativada, mas todas as outras também morreram em temperatura de $45^{\circ} \mathrm{C}$ após 14 dias. Já em temperatura mais baixa, apesar de haver inativação, esta foi menor.

Abushelaibi et al. (2003) estudaram cereais infantis (arroz, mingau de aveia e mistura de cereais) reidratados com água, leite ou suco de maçã e testaram a sobrevivência e multiplicação de Salmonella nestes alimentos durante 24 horas de armazenamento em diferentes temperaturas. Estes autores observaram que quando a contaminação com Salmonella era superior a $4 \log$ UFC/g não houve diferença na multiplicação de Salmonella em cereais infantis hidratados com água, com leite ou com suco de maçã, durante armazenamento à $4^{\circ} \mathrm{C}$ por 24 horas. Contudo, em temperaturas de abuso $\left(15^{\circ} \mathrm{C}\right.$ e $\left.25^{\circ} \mathrm{C}\right)$ houve multiplicação de Salmonella durante o armazenamento, particularmente quando se hidratou os cereais com líquidos com pH próximo do neutro, como a água e o leite.

Jung \& Beuchat (1999) analisaram a sobrevivência de Salmonella Typhimurium DT104 multi-resistente a antibióticos e de Salmonella Typhimurium não DT104 (sensível a antibióticos) em ovo em pó com diferentes Aa, armazenados em diferentes temperaturas. Estes autores observaram que não houve diferença no comportamento das duas cepas testadas. Verificaram também que as cepas sobreviveram mais tempo quando estocadas a $13^{\circ} \mathrm{C}$ do que a $37^{\circ} \mathrm{C}$.

Baron, Gautier \& Brulé (1999) demonstraram que Salmonella Enteritidis, inoculada em clara em pó reconstituída, tem multiplicação comparável à observada em meio de cultura. 
Segundo os mesmo autores (1997), o ovo "in natura" não é um bom meio para a multiplicação de microrganismos, por causa de seus fatores intrínsecos, que incluem a lisozima, que rompe bactérias gram-positivas, a ovotransferrina, que retira o ferro do meio, o qual é essencial para multiplicação, o ovomucoide que é inibidor de proteinase e as proteínas que se ligam a vitaminas, como a avidina que se liga a riboflavina e a tiamina, que inibem crescimento destes microrganismos. Estes autores observaram que esta multiplicação ocorre por causa da desnaturação da ovotransferrina durante o processo de pasteurização e pelo aumento da disponibilidade de ferro.

As Tabelas 21, 22, 23 e 24 apresentam os resultados do teste de médias de Duncan para as amostras de ovo com Aa de cerca de 0,4,0,6,0,8 e 0,9, respectivamente, nas temperaturas de $8^{\circ} \mathrm{C}, 15^{\circ} \mathrm{C}, 25^{\circ} \mathrm{C}$ e $35^{\circ} \mathrm{C}$. Nestas tabelas, na coluna do grupo de Duncan, letras iguais indicam diferença estatística não significativa $(p<0,05)$ entre os resultados obtidos para uma dada combinação entre Aa, temperatura e tempo de armazenamento.

Para o ovo com Aa 0,4 armazenado por 7 dias, não há diferença significativa nos resultados obtidos no produto armazenado a $8^{\circ} \mathrm{C}, 15^{\circ} \mathrm{C}$ ou $25^{\circ} \mathrm{C}$. Entretanto, os resultados referentes à cinética de multiplicação de Salmonella Enteritidis nessas 3 temperaturas são significativamente diferentes dos obtidos para a temperatura de $35^{\circ} \mathrm{C}$.

A relação existente entre a capacidade de sobrevivência da Salmonella Enteritidis em ovo em pó com diferentes valores de Aa, para uma mesma temperatura e para um mesmo tempo de armazenamento está apresentada nas Tabelas 25 a 32 . Através destas podemos, por exemplo, ver que, quando o ovo é armazenado por 21 dias a $8^{\circ} \mathrm{C}$ (Tabela 27), não exite diferença significativa entre os resultados obtidos nas quatro Aa testadas, mas para o mesmo período de armazenamento e mesma temperatura, há diferença significativa entre os resultados obtidos nas amostras armazenadas nas outras três temperaturas estudadas.

Para comparação do comportamento de Salmonella Enteritidis sensivel aos antibióticos com o de Salmonella Hadar resistente a diversos antibióticos, selecionou-se o ovo em pó com Aa de cerca de 0,6 , porque nessa Aa os resultados foram permitiram uma melhor avaliação da influência da temperatura de armazenamento. Após 56 dias de armazenamento em temperatura de $8^{\circ} \mathrm{C}$, admitindo-se que a contaminação inicial da cepa não resistente era de $10^{4} \mathrm{UFC} / \mathrm{g}$ e a da cepa resistente era de $10^{3} \mathrm{UFC} / \mathrm{g}$, a cepa não resistente (Tabela 5) apresentou um decréscimo de 1,2 ciclos $\log$, enquanto a resistente (Tabela 17) apresentou uma redução de 2,1 ciclos log. Na 
temperatura de $15^{\circ} \mathrm{C}$, houve um decréscimo de 2,2 ciclos log após os 56 dias de armazenamento para a cepa não resistente (Tabela 6). Já para a cepa resistente (Tabela 18), não foi possível detectá-la com 49 dias de armazenamento nessa temperatura. $\mathrm{Na}$ temperatura de $25^{\circ} \mathrm{C}$, não foi possivel isolar nenhuma das duas cepas (Tabelas 7 e 19) com 21 dias de armazenamento. Por último, para a temperatura de $35^{\circ} \mathrm{C}$, houve um rápido decréscimo na contagem de Salmonella no produto, a cepa não resistente (Tabela 8) não foi mais detectada após 14 dias de armazenamento nessa temperatura, enquanto que para a cepa resistente (Tabela 20) esse tempo foi de 7 dias. $\mathrm{O}$ teste $t$ pareado de Student indicou que não houve diferença estatisticamente significativa $(p<0,05)$ no comportamento das cepas resistente e não resistente no ovo com Aa de cerca de 0,6 , independente da temperatura de armazenamento. Este resultado está de acordo com o encontrado por Jung \& Beuchat (1999), que, ao estudarem 4 cepas de Salmonella Typhimurium resistentes a antibióticos e 4 cepas não resistentes, observaram que não houve diferença na capacidade de sobreviver nos diversos produtos testados.

Os resultados deste trabalho evidenciaram a importância da pasteurização adequada do ovo líquido na fabricação de ovo em pó, bem como do controle da contaminação pósprocessamento por microrganismos patogênicos, principalmente Salmonella, que é o microrganismo mais freqüentemente associado aos surtos de casos de DTAs envolvendo ovos e alimentos à base de ovos. 


\section{Conclusões}

Em função dos resultados obtidos nesse trabalho, as conclusões de maior relevância são:

1. Salmonella Enteritidis é capaz de sobreviver por longo tempo (pelo menos 56 dias) em ovo em pó com Aa próximo de 0,4 quando armazenado a $8^{\circ} \mathrm{C}, 15^{\circ} \mathrm{C}$ ou $25^{\circ} \mathrm{C}$. Essa sobrevivência é menor (até 28 dias) quando o armazenamento é feito a $35^{\circ} \mathrm{C}$.

2. No ovo em pó com Aa em torno de 0,6 ou 0,8 , Salmonella Enteritidis sobrevive por menos tempo do que no produto com Aa de cerca de 0,4 , independentemente da temperatura de armazenamento.

3. No produto com Aa de cerca de 0,9 , há grande multiplicação de Salmonella Enteritidis quando o armazenamento é feito a $15^{\circ} \mathrm{C}, 25^{\circ} \mathrm{C}$ ou $35^{\circ} \mathrm{C}$. No produto com essa Aa, o armazenamento a $8^{\circ} \mathrm{C}$ impede a multiplicação do patógeno.

4. O fato de Salmonella ser resistente a antibióticos nâo influencia na sua capacidade de sobreviver ou multiplicar no ovo em pó com Aa de cerca de 0,6 , independentemente da temperatura e tempo de armazenamento. 


\section{Referência Bibliografica}

Abushelaibi, A.A.; Sofos, J.N.; Samelis, J.; Kendall, P.A. Survival and growth of Salmonella in reconstituted infant cereal hydrated with water, milk or apple juice and stored at $4^{\circ} \mathrm{C}, 15^{\circ} \mathrm{C}$ and $25^{\circ} \mathrm{C}$. Food Microbiology. v.20, p.17-25, 2003.

Aguirre, J.M.; Travaglini, D.A.; Silveira, E.T.F. Desidratação de Ovos. Boletim do Instituto de Tecnologia de Alimentos. v.16, n.23, p.261-287, 1979.

Altekruse, S.F.; Cohen, M.L.; Swerdlow, D.L. Emerging foodborne diseases. Emerg. Infect. Dis. v.3, p.285-293, 1997.

Andrews, W.H.; Bruce, V.R.; Jung, G.; Satchel, F.; Sherrod, P. Salmonella. In: USA Food and Drug Administration. Bacteriological Analytical Manual. Gaithersburg: AOAC International. 8ed. pp.5.01-5.020, 1995.

Andrews, W.H.; Hammack, T.S. Salmonella. Bacteriological Analytical Manual Online, 2003. Disponivel em: Internet: http:// www.cfsan.fda.gov/ eban/ban-5.html. Acessado em 9 de dezembro de 2004 .

Archer, J.; Jervis, E.T.; Bird, J.; Gaze, J.E. Heat Resistance of Salmonella weltevreden in LowMoisture Environments. J. Food Prot. v.61, n.8, p.969-973, 1998.

Banwart, G.J. Effect of sodium chloride and storage temperature on the growth of Salmonella oranienburg in egg yolk. Poultry Sci. v.43, p.973-976, 1964.

Baron, F.; Gautier, M.; Brulé, G. Factors involved in the inhibition of growth of Salmonella enteritidis in liquid egg white. J. Food Prot. v.60, n.11, p.1318-1323, 1997

Baron, F.; Gautier, M; Brulé, G. Rapid growth of Salmonella Enteritidis in egg white reconstituted from industrial egg white powder. J. Food Prot. v.62, n.6, p.585-591, 1999. 
Barretto, P.A.A. Ovos Ito. Informe Técnico. São Paulo, 2001.

Bean, N.H.; Goulding, J.S.; Daniels, M.T; Angulo, F.J. Surveilance for foodborne disease outbreaks United States, 1998-1992. J. Food Prot. v.60, p.1265-1286, 1997.

Bergquist, D.H. Egg Dehydration. In: Stadelman, W.J. \& Cotteril, O.J. Egg Science and Technology, 3ed. Westport, Connecticut, AVI Publishing Company, Inc. pp.285. 1986.

Carvalho, J.C.A.P.; Franco, R.M.; Oliveira, L.A.T. Qualidade Microbiológica do Ovo Integral Desidratado Produzido no Brasil. Higiene Alimentar, v.32, n.8, p.38-46, 1994.

Center for Disease Control and Prevention. Incidebce of foodborne illnesses. Preliminary data from the Foodborne Diseases Active Surveilance Network (FoodNet) United States, December 1998. MMWR 48, p.189-194, 1999.

Center for Disease Control and Prevention. Preliminary FoodNet data on the incidence of foodbome illnesses selkected sites, United States, 2000. MMWR 50, p.241-246, 2001.

Christian, J.H.B.; Stewart, B.J. Survival of Staphylococcus aureus and Salmonella newport in dried foods as influenced by water activity and oxigen. In: Microbiological Safety of Food. Preceedings of $8^{\text {th }}$ Internacional Symposium on Food Microbiology. Academic Press, London, p.107-119.

Cotteril, O.J.; Glaubert, J. Destruction of Salmonella oranienburg in egg yolk containing various concentrations of salt at low temperatures. Poultry Sci. v.51, p.1060-1061, 1972.

CVE (Centro de Vigilância Epidemiológica), Surtos de Doenças Transmitidas por Água e Alimentos no Estado de São Paulo - Ano 2001. Disponível em: Internet: www.cve.saude.sp.gov.br. Acessado em 03 Nov 2004. 
CVE (Centro de Vigilância Epidemiológica), Surtos de Doenças Transmitidas por Água e Alimentos no Estado de São Paulo - Ano 2002. Disponível em: Internet: www.cve.saude.sp.gov.br. Acessado em 03 Nov 2004.

Hanes, D. Nontyphoid Salmonella. In: Miliotis, M.D.; Bier, J.W. International Handbook of foodborne Pathogens. New York: Marcel Dekker, INC., 2003. Cap.9, p.137-150.

D'Aoust, J-Y. Salmonella species. In: Doyle, M.P. Foodborne Bacterial Pathogens. New York: Marcel Dekker, 1989. Cap. 9, p. 327-445.

D'Aoust, J-Y. Salmonella species. In: Doyle, M.P., Beuchat, L.R., Montville, T.J. Food Microbiology - Fundamentals and Frontiers. Washington: American Society for Microbiology, 1997. Cap. 8, p. 129-158.

D'Aoust, J.Y. Pathogenicity of foodborne Salmonella. Int. J. Food Microbiol.v.12, p.17-40, 1991.

D’Aoust, J.Y. Salmonella. Species. In: Doyle, M.P., Beuchat, L.R. and Montville, T.J. (eds.). Food Microbiology: fundamentals and frontiers. Washington, D.C.: ASM Press, 2001. pp. 141-178.

Delazari, I. Aspectos microbiológicos de alimentos desidratados. Boletim do Instituto de Tecnologia dos Alimentos. v.16, n.3, p.227-260, 1979.

Dias, Á.P; Ajzental, A; Calil, R.M. Avaliação da microbiota pré e pós-pasteurização do ovo líquido. Higiene Alimentar. v.16, n. 100, p.127-133, 2002.

Doyle, M.E; Mazzotta, A.S. Review of studies on the thermal resistance of Salomonellae. J. Food Prot. v.63, n.6, p.779-795, 2000. 
Dreesen, D.W; Barnhart, H.M.; Burke, J.L.; Chen, T.; Johnson, D.C. Frequency of Salmonella enteritidis and other salmonellae in the ceca of spent hens at time of slaughter. Avian Dis., v.36, p.247-50, 1992 .

Ebel, E.; Schlosser, W. Estimating the annual fraction of eggs contaminated with Salmonella enteritidis in the United States. Int. J. Food Microbiol. v.61, p.51-62, 2000.

El-Gazzar, F.E., Marth, E.H. Salmonellae, salmonellosis and dairy foods: a review. J. Food Sci. v.75, p.2327-2343, 1992.

Franco, B.D.G.M., Landgraf, M. Microbiologia dos Alimentos. São Paulo: Editora Atheneu, 1996. Cap. 4 , p.55-60

Franco, B.D.G.M.; Landgraf, M.; Destro, M.T.; Gelli, D.S. Foodborne Disease in Southern South America. In: Miliotis, M.D.; Bier, J.W. International Handbook of foodborne Pathogens. New York: Marcel Dekker, INC., 2003. Cap.45, p.733-743.

Fuzihara, T.O.; Fernandes, S.A.; Franco, B.D.G.M. Prevalence and dissemination of Salmonella serotypes along the slanghtering process in Brazilian small poultry slaughterhouses. J. Food Prot. v.63, n.12, p.1749-1753, 2000.

Garthright, W.E. Apendix 2. Most probable number from serial dilutions. In: USA. Food and Drug Administration. Bacteriological Analytical Manual. 8 ed. Gaithersburg: AOAC Internacional (Revision A), p. Appl. 2.01-2.08. 1998.

Gast-Richard, K; Holt-Peter, S. Influence of the level and location of contamination on the multiplication of Salmonella enteritidis at different storage temperatures in experimentally inoculated eggs. Poultry Sci.v.79(4), p.559-563, 2000.

Goepert, J.M.; Iskander, J.K.; Amundson, C.H. Relation of the Heat Resistance of Salmonellae to the Water Activity of the Environment. Appl. Microbiol. v.19, n.3, p.429-433, 1970. 
Gordon, A. Egg products. I. Process Technology. Food Processing Industry, v.40, n.473 p.2730. 1971 .

Hedberg, C.W. Epidemiology of Foodborne Illnesses. In: Doyle et al. Food microbiology: Fundamentals and Frontiers. $2^{\text {nd }}$ ed. Washington: ASM Press, 2001 cap.20, p.435-447.

Hitchins, A.D.; Feng, P.; Watkins, W.D.; Rippey, S.R.; Chandler, L.A. Escherichia coli and the coliform bacteria. In: USA. Food and Drug Administration. Bacteriological Analytical Manual. $8^{\mathrm{a}}$ Ed. Gaithersburg: AOAC International (Revision A). Cap.4, p.4.01-4.29. 1998.

Holt, J.G; Krieg, N.R; Sneath, P.H.A.; Stanley, J.T.; Williams, S.T. Bergey`s Manual of Determinative Bacteriology. Maryland: Lippincott Willians \& Wilkins, 1994. 787 p.

Hu, L; Kopecko, D.J. Typhoid Salmonella. In: Miliotis, M.D; Bier, J.W. International Handbook of foodborne Pathogens. New York: Marcel Dekker, INC., 2003. Cap.10, p.151-165.

IBGE (Instituto Brasileiro de Geografia e estatística), 2002. disponível em: Internet: http://www.IBGE.com.br/Home/estatistica/economia/ppm/2002/PPM2002.pdf. Acessado em 2 de dezembro 2004.

IBGE (Instituto Brasileiro de Geografia e estatistica), 2004. disponível em: Internet: http://www.IBGE.com.br. Acessado em 2 de dezembro de 2004.

Ibrahim, H.R. Ovotransferrin. In: Naidu, A.S. Natural Food Antimicrobial Systems. Florida: CRC Press, 2000. c.7, p.211-226.

International Commission on Microbiological Specifications for Foods (ICMSF). Eggs and egg products. In: Microorganisms in Foods 6 - Microbial Ecology of Food Commodities. Blackie Academic \& Professional, London, p.475-511. 1998. 
Jay, J.M. Modern Food Microbiology. Maryland: An Aspen Publication, 2000. 679p.

Jung, Y.S.; Beuchat, L.R. Survival of multidrug-resistant Salmonella typhimurium DT104 in egg powders as affected by water activity and temperature. Int. J. Food Microbiol. v.49, p.1-8. 1999.

Juven, B.J.; Cox, N.A.; Bailey, J.S.; Thompson, IE.; Charles, O.W.; Shutze, J.V. Survival of Salmonella in Dry Food and Feed. J. Food Prot. v.47, n.6, p.445-448, 1984.

Licari, J.J.; Potter, N.N. Salmonella survival During Spray Drying and Subsequent Handling of Skimmilk Powder. III. Effects of Storage Temperature on Salmonella and Dried Milk Properties. Journal of Dairy Sciences. v.53, n.7, p.877-882, 1970.

Losso, J.N.; Nakai, S.; Charter, E.A. Lysozime. In: Naidu, A.S. Natural Food Antimicrobial Systems. Florida: CRC Press, 2000. c.6, p.185-210.

Mañas, P.; Pagán, R.; Alvarez, I.; Usón, S.C. Survival of Salmonella senftenberg $775 \mathrm{~W}$ to current liquid whole egg pasteurization treatments. Food Microbiology. v.20, p.593-600, 2003.

Maturin, L.J.; Peeler, J.T. Aerobic Plate Count. In: USA. Food and Drug Administration. Bacteriological Analytical Manual. $8^{a}$ ed. Gaithersburg: AOAC international (Revision A). Cap.3, p.3.01-3.10. 1998.

Mine, Y. Avidin. In: Naidu, A.S. Natural Food Antimicrobial Systems. Florida: CRC Press, 2000. c. 9, p. $253-264$.

Palumbo, M.S.; Beers, S.M.; Bhaduri, S.; Palumbo, S.A. Thermal resistance of Salmonella spp and Listeria monocytogenes in liquid egg yolk and egg yolk products. J. Food Prot. v.58 n.9, p.960-966, 1995 . 
Pereda, J.A.O; Rodríguez, M.I.C; Alvarez, L.F; Sanz, M.L.G; Minguillón, G.D.G.F; Perales, L.L.H; Cortecero, M.D.S. Tecnologia de Alimentos. Tradução Fátima Murad. Porto Alegre: ARTMED Editora S.A., 2005.

Pereira, M.L.; Carmo, L.S.; Martins Vieira, M.B.C. Presença de Salmonella em linguiça frescal. Influência da metodologia de pesquisa e avaliação de antibiotico-resistência do microrganismo. Ciênc. Tecnol. Aliment. v.9, p.115-137, 1989.

Popoff, M.Y.; Bockemühl, J.; Brener, F.W. Supplement $1997\left(\mathrm{n}^{\circ} .41\right)$ to the Kauffman-white scheme. Rev. Microbiol., Paris, n.149, p.601-604, 1998.

Radkowski, R. Survival of Salmonella spp. in whole powdered egg. Archiv für Lebensmittelhygiene. v.53, n.3, p.60-61, 2002.

Reis, R.B.; Kruger, C.S.; Maciel, M.S. Salmonella spp em produtos cárneos comercializados no município de Cuiabá - MT. Avaliação da metodologia de pesquisa. Modelos de resistência a drogas antimicrobianas. Ciênc. Tecnol. Aliment. v.15, n.1, p.74-78, 1995.

Revista Avicultura Industrial. №1029. Fevereiro, 1996.

Silva, E.N; Duarte, A Salmonella Enteritidis em aves: retrospectiva no Brasil. Revista brasileira de Ciência Avícola. v.4, n.2, p.85-100, 2002.

Sim, J.S; Sunwoo, H.H; Lee, E.N. Ovoglobulin IgY. In: Naidu, A.S. Natural Food Antimicrobial Systems. Florida: CRC Press, 2000. cap.8, p.227-252.

SIRVETA (Sistema de Informacion para la Vigilância de Las Enfermidades Transmitidas por los Alimentos), 2004. Disponível em: Internet:

http://www.panalimentos.org/sirveta/e/grafb 02.asp?frmAnDesde=1993\&frmAnHasta=2002 \&frmPais=Todos\&frmEnfermedad=Todas\&Acept=Aceptar. Acesso em 03 Nov 2004. 
SIRVETA (Sistema de Informacion para la Vigilância de Las Enfermidades Transmitidas por los Alimentos), 2004. Disponível em: Internet:

http://www.panalimentos.org/sirveta/e/grafb_02.asp?frmAnDesde=1993\&frmAnHasta=2002 \& frmPais=Todos\&frmEnfermedad=Salmonelosis\&Acept=Aceptar. Acesso em 03 Nov 2004.

SIRVETA (Sistema de Informacion para la Vigilância de Las Enfermidades Transmitidas por los Alimentos), 2004. Disponivel em: Internet:

http://www.panalimentos.org/sirveta/e/grafb_02.asp?frmAnDesde=1993\&frmAnHasta=2002 $\underline{\text { \&frmPais=Brasil\&frmEnfermedad=Todas\&Acept=Aceptar. }}$. Acessado em 03 Nov 2004.

SIRVETA (Sistema de Informacion para la Vigilância de Las Enfermidades Transmitidas por los Alimentos), 2004. Disponível em: Internet:

http://www.panalimentos.org/sirveta/e/grafb 02.asp?frmAnDesde=1993\&frmAnHasta=2002 \&frmPais=Brasil\&frmEnfermedad=Salmonelosis\&Acept=Aceptar. Acessado em 03 Nov 2004 .

SIRVETA (Sistema de Informacion para la Vigilância de Las Enfermidades Transmitidas por los Alimentos), 2004. Disponível em: Internet:

http://www.panalimentos.org/sirveta/e/salida2.asp?xls=si. Acessado em 03 Nov 2004.

Solomon, S.E.; Bain, M.M.; Cranstoun, S.; Nascimento, V. Hen's egg stucture and function. In: Microbiology of the Avian Egg (eds. R.G. Board and R. Fuller). Chapman \& Hall, London, p. 1-24, 1994.

Sparks, H.C. Shell acessory materials: structure and functions. In: Microbiology of the Avian Egg (eds. R.G. Board and R. Fuller). Chapman \& Hall, London, p. 25-42, 1994.

Tietjen, M.; Fung, D.Y.C. Salmonellae and food safety. Crit. Rev. Microbiol. v.21, p.53-83, 1995. 
Anexos 
Anexo 1: Comportamento de Salmonella Enteritidis em ovo em pó com Aa de cerca de 0,4 , durante armazenamento por até 56 dias, a $8^{\circ} \mathrm{C}, 15^{\circ} \mathrm{C}, 25^{\circ} \mathrm{C}$ e $35^{\circ} \mathrm{C}$.

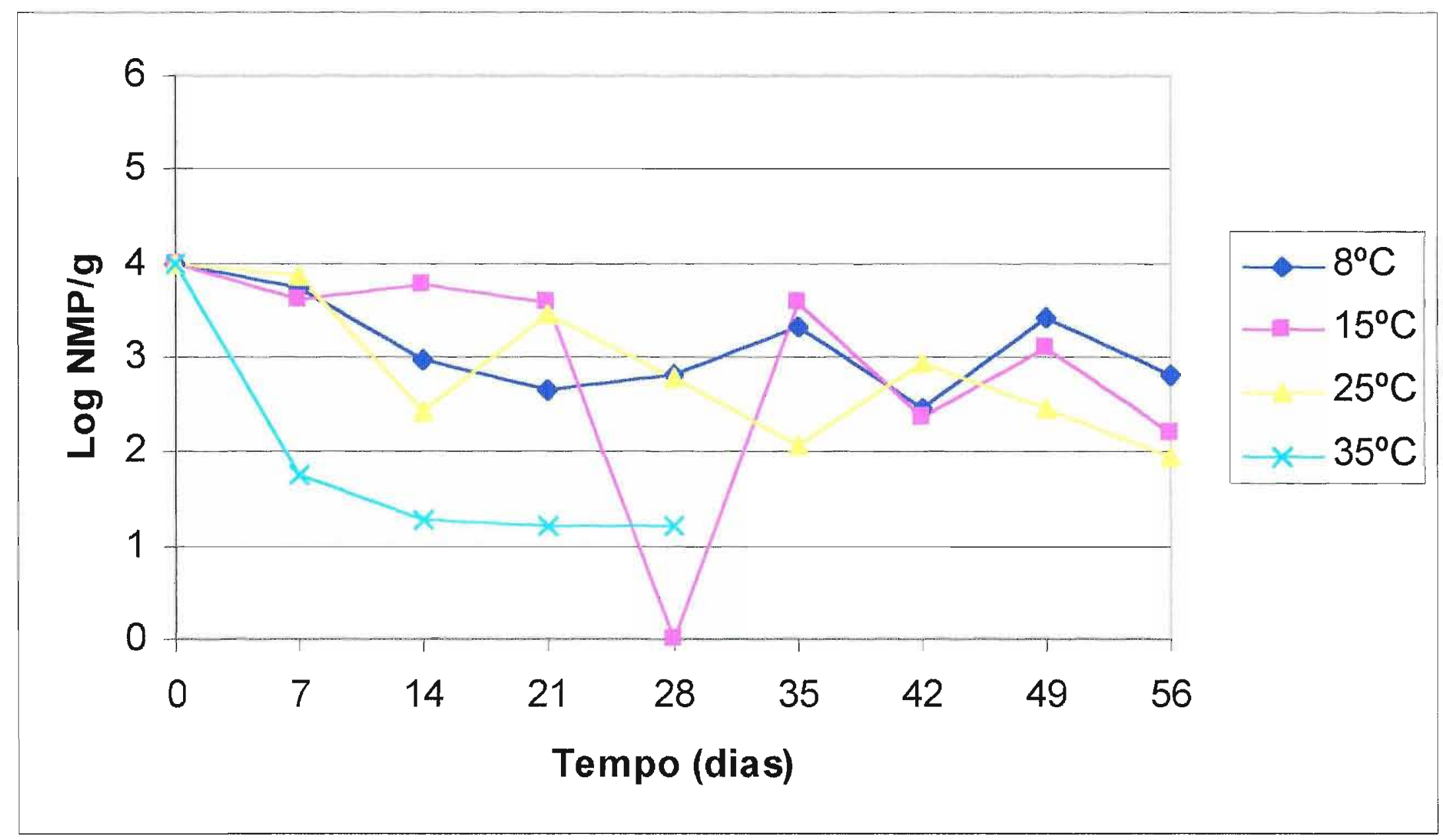


Anexo 2: Comportamento de Salmonella Enteritidis em ovo em pó com Aa de cerca de 0,6, durante armazenamento por até 56 dias, a $8^{\circ} \mathrm{C}, 15^{\circ} \mathrm{C}, 25^{\circ} \mathrm{C}$ e $35^{\circ} \mathrm{C}$.

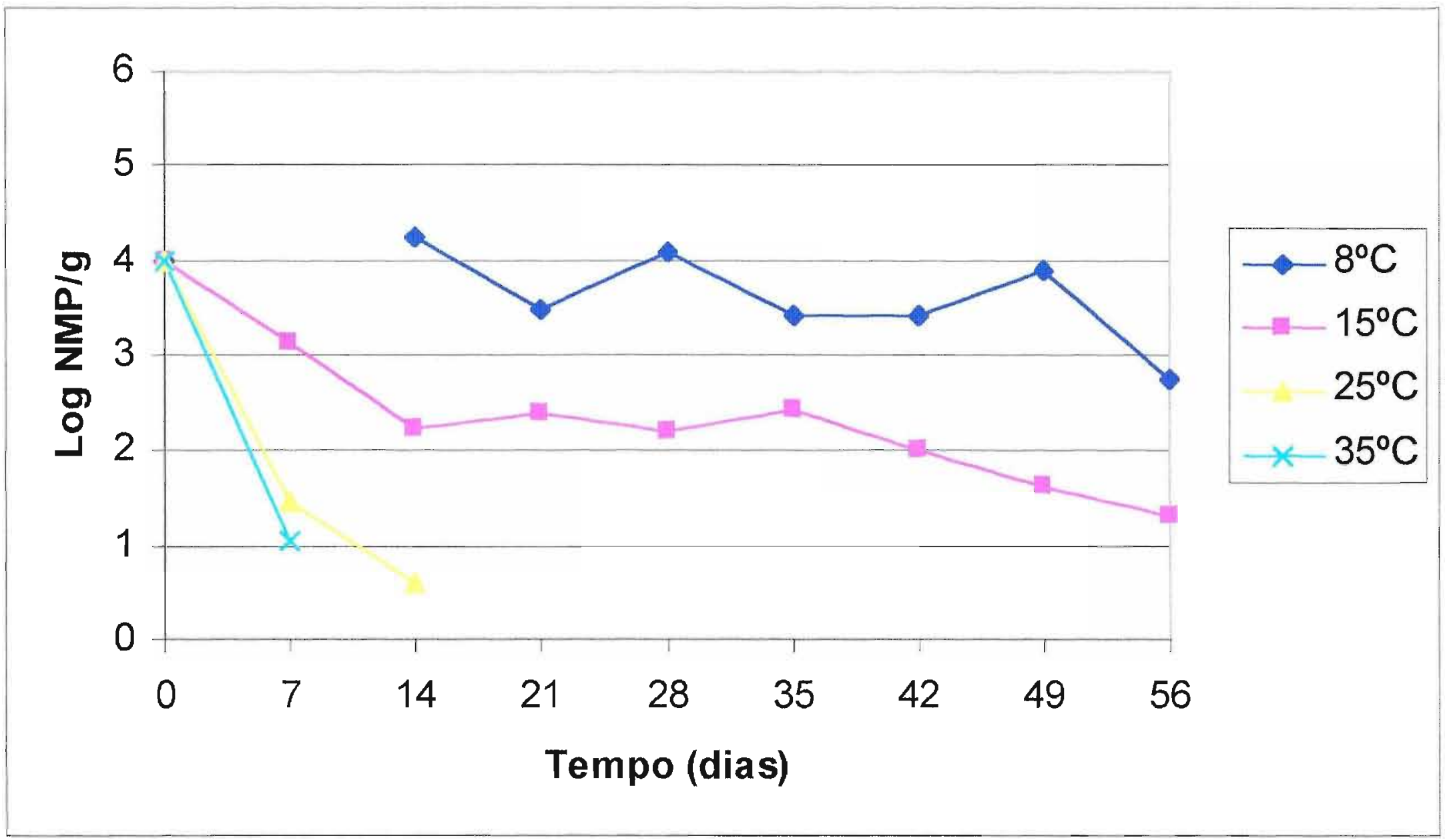


Anexo 3: Comportamento de Salmonella Enteritidis em ovo em pó com Aa de cerca de 0,8 , durante armazenamento por até 56 dias, a $8^{\circ} \mathrm{C}, 15^{\circ} \mathrm{C}, 25^{\circ} \mathrm{C}$ e $35^{\circ} \mathrm{C}$

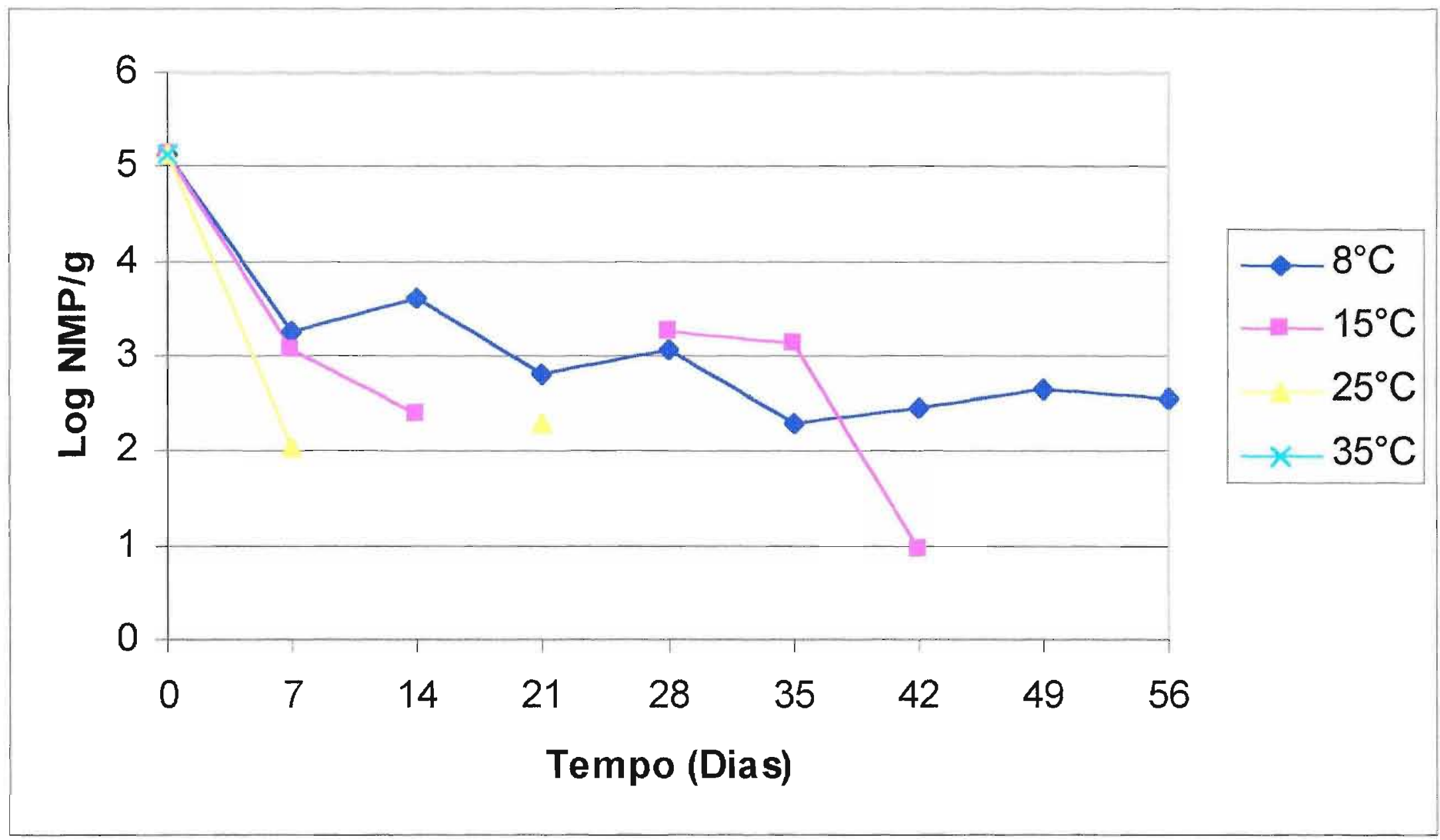


Anexo 4: Comportamento de Salmonella Enteritidis em ovo em pó com Aa de cerca de 0,93, durante armazenamento por até 56 dias, a $8^{\circ} \mathrm{C}, 15^{\circ} \mathrm{C}, 25^{\circ} \mathrm{C}$ e $35^{\circ} \mathrm{C}$.

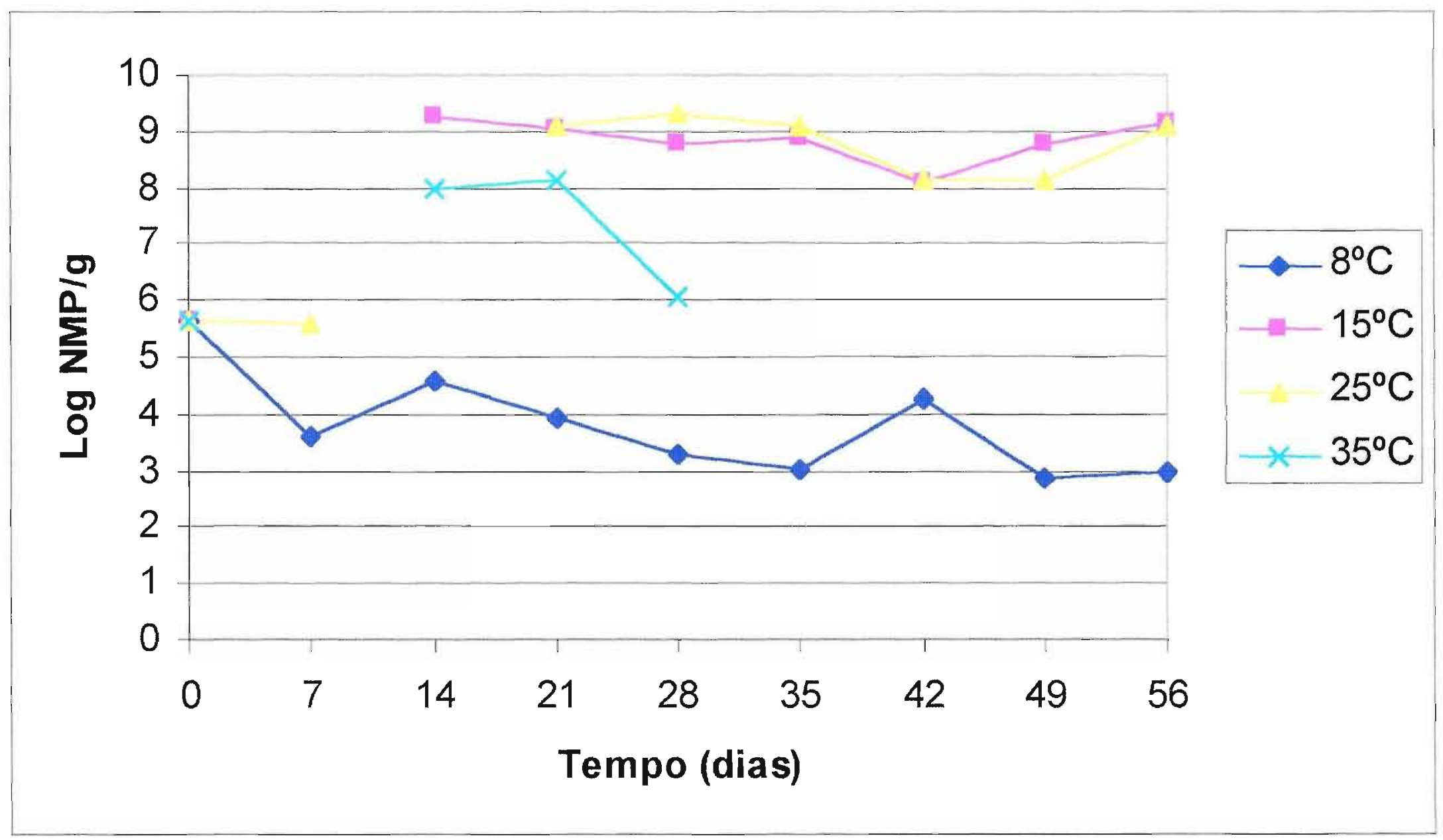


Anexo 5: Comportamento de Salmonella Hadar em ovo em pó com Aa de cerca de 0,6, durante armazenamento por até 56 dias, a $8^{\circ} \mathrm{C}$, $15^{\circ} \mathrm{C}, 25^{\circ} \mathrm{C}$ e $35^{\circ} \mathrm{C}$.

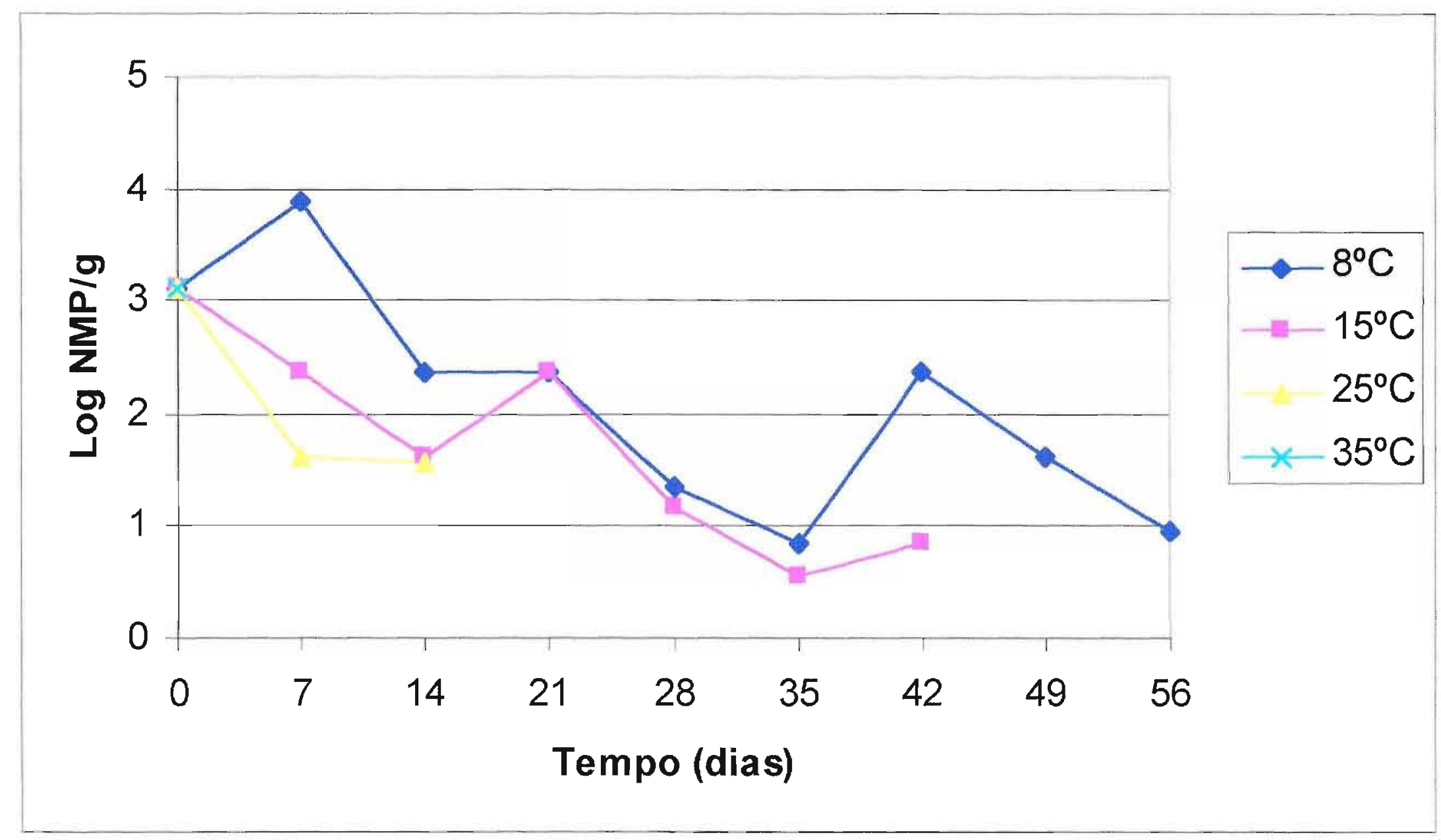

